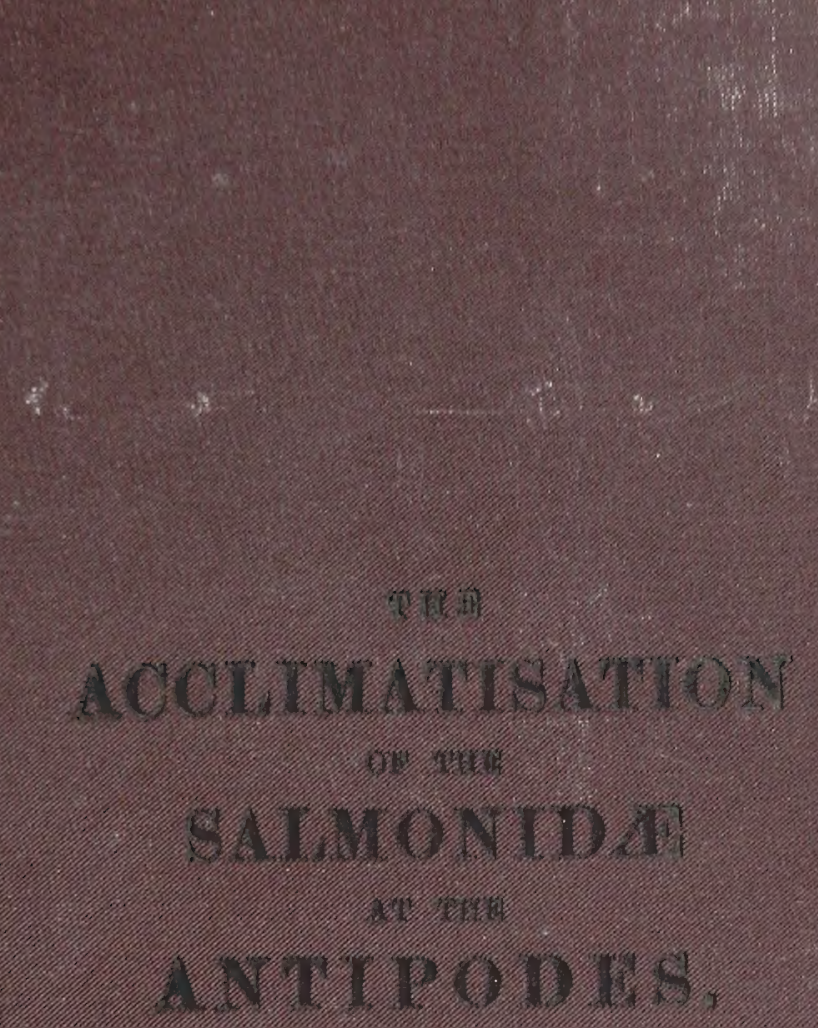




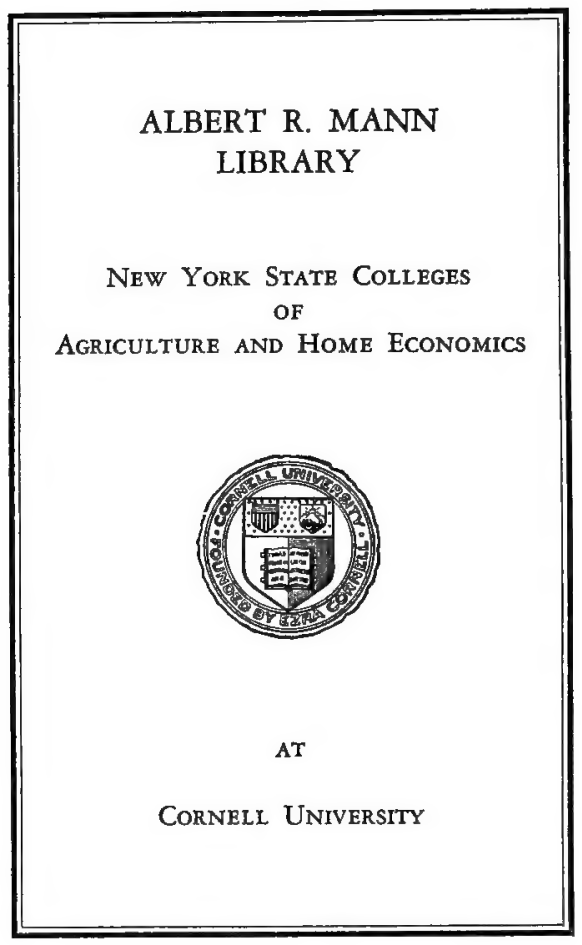




\section{SH 167 Cornell University Library}

\section{S17N65}

The acclimatisation of the Salmonidae at

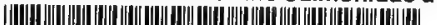

$\begin{array}{llllll}31924003231 & 150\end{array}$ 


\section{Cornell University Library}

The original of this book is in the Cornell University Library.

There are no known copyright restrictions in the United States on the use of the text. 


\title{
THE ACCLIMATISATION
}

OF THE

\section{SALMONID压 AT THE ANTIPODES:}

\author{
ITS HISTORY AND RESULTS.
}

BY

ARTHUR NICOLS, F.G.S., F.R.G.S.,

AUTHOR OF "ORAPTERS FROM THE PHYSICAT HISTORY OF THE EARTH;

AN INTRODUCTION TO GEOLOGY AND PALFONTOLOGY,"

THE PCZZLE OF LIFE, AND HOW IT HAS BEEN PUT TOGETHER,"

AND

ZOOLOGICAL NOTES ON WILD AND DOMESTIC ANIMALB."

Nusquam Magis quam in Minimis tota est Natura."-BAcos.

\section{LONDON :}

SAMPSON LOW, MARSTON, SEARLE, \& RIVINGTON.

1882.

All rights reserved. 
JNWIN BROTHERS, PRINTERS, CHILWORTH AND LONDON. 
TO THE

ACCLIMATISATION SOCIETIES OF AUSTRALIA, TABMANIA AND

NEW ZEALAND,

AND THE SALMON COMMISSIONERS OF TASMANIA;

WHOSE PUBLIO ŞPIRIT IN GOLLEOTING FUNDS FOR DEFRAYING THE

DXPENGES OF TRANSMISSION, IN CONJUNCTION WITH THE

SUBSEQUENT CARE AND ATTENTION BESTOWED UPON TEE OVA AND FIY,

has So LARGELY CONTRIBUTED TOWARDS THE PERMANENT

NATURALISATION OF TEE SALMON AND TROUT

IN THE WATERS OF AUSTRALASIA,

THE AUTHOR

BEGS RESPECTFULLY TO DEDICATE THIS HISTORY

OF A SIGNAI ACHIEVEMENT IN

PISCIOULTURE. 



\section{PREFACE.}

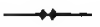

The frequent demand, both at home and in the Australasian colonies, for a series of articles on the acclimatisation of the Salmonidee at the Antipodes, which I contributed to the Field Quarterly Magazine and Review, The Country, and Chambers' Journal, and which are now out of print, has determined me to republish the substance of them with additions, forming a short but complete history of this remarkable achievement, fraught as it is with important economic results for those colonies; and with so many points of scientific interest. 
I have had the advantage of inspecting all the public documents and every private letter of any importance bearing upon the subject, since the earliest experiments were made in the direction which ultimately led to success; and I must express my cordial thanks to Mr. J. A. Youl, C.M.G., for the valuable assistance he has rendered me in placing at my disposal a large number of letters and memoranda, not otherwise accessible, the most important of which will be found in the Appendix.

An astonishing amount of error, even with respect to easily ascertained facts, has been disseminated by both the colonial and English press. The Field, The Melbourne Argus, and The Times have, however, been exceptions.

It has been my self-appointed and pleasing task to examine as critically as I was able every published statement, whether of fact 
or inference, in connection with this subject; and while, I trust, credit has been given wherever within my knowledge it is due, my duty to the reader has compelled me to point out where it has been unjustly claimed or attributed.

In constituting myself the historian of this work-the commercial importance of which cannot be realised for many years to come, while its scientific interest is already fully acknowledged - I desire to assume the entire responsibility of the following pages.

A. N.

London, May, 1882. 



\section{EARLY ENDEAVOURS}

\section{TO ACCLIMATISE THE SALMON.}

$\mathrm{H}$ who succeeded in making two blades of grass grow where but one grew before has been canonised as the greatest benefactor of mankind, but surely he who achieves the more difficult task of transplanting an animal from one hemisphere to the other, and peopling a barren river with a noble species of fish, should not pass unnoticed by his contemporaries and those who enter into the enjoyment of his labour.

The Australasian colonies fortunately possess acclimatisation societies directed by men of ability and energy, who have 
left nothing undone to establish in the New World the most desirable animal colonists from the old. If they have made a mistake here and there, and have introduced an unmitigated pest like the rabbit, they will one day find compensation in stalking the red deer and bringing the lordly salmon to grass among picturesque granitic hills, which may well recall to the eye of the sportsman many a wild scene in the highlands of bonnie Scotland or the softer glories of the Irish lakes. Long before the end of this century, when probably the ploughshare will have invaded the haunts of the red deer, and manufacturing "interests" and a growing population shall have driven the salmon in disgust from most of our rivers-when even Scandinavia's pure waters have been tainted by civilisation-the sportsman will take his rifle and rod, and seek among the ferncovered ranges of the Australian Alps and the deep tarns and pools of Tasmania and New Zealand, the noble quarry which has found a congenial home at the Antipodes. 
Whether this is an over-sanguine anticipation of the ultimate results of a brilliant exploit in acclimatisation, the reader will be enabled to judge from the account I propose to give of the introduction of the salmon family into the waters of the southern hemisphere, and the measure of success at present attained.

Why have not salmon found their way to the other hemisphere without man's intervention? we may reasonably ask. They range in the northern hemisphere between latitude $45^{\circ}$ and $75^{\circ}$, though they may penetrate wherever there is open water to the northward, and the recent Arctic Expedition found a salmonoid permanently established at $80^{\circ} \mathrm{N}$. latitude. Their physical constitution, then, is adapted to cool waters, and the zone of warm water occupying the tropics presents an impassable obstacle to southern migration. Moreover, they would never find, in their journey towards the south, any river the water of which would be low enough in temperature to permit the safe development of the ova, and it is there- 
fore impossible that their migration could have been effected by easy stages. So far as is yet known, no true member of the family is indigenous to any region south of the equator, though a distant and obscure relative is found in some of the rivers of India, and another in New Zealand and the streams of the Falkland Islands, which has some characters common to the group, but is otherwise so distinct that no one ignorant of anatomy would suspect the remotest connection of these impostors with the noble stock. The colonists, however, have given local names to many animals on account of slight resemblances of colour or form to those they have been familiar with in the Old Country, and this has led to much confusion and misapprehension of the natural history of Australasian fauna which it is a hard task to correct.

We may say with truth, "Illi robur et æs triplex circa pectus erat". who first committed the fragile ova of the salmon to the truculent ocean, and essayed to transport them some sixteen thousand miles in the 
hold of a ship, where they would be exposed to a temperature ranging between the freezing point and $95^{\circ}$, and in the space of three months would experience two winters and a tropical summer!

Looking back upon the dark past through the light of present experience, we are apt to lose sight of the steps which have led to knowledge. Thirty jears ago there was positively no experience of the conditions under which it was possible to convey the ova of fish long distances. All was tentative, experimental, and uncertain; but we now regard as an interesting but not surprising feat the acclimatisation of fish from the West of America in the waters of the East, and vice versâ, or the transport of sterlet from the Volga to Scotland.

It is easy enough to look with complacent satisfaction on a finished work, and think nothing of the care, perseverance, and intelligence expended in accomplishing it. Ask the director of the Brighton Aquarium how he brought the octopus, the porpoise, the herrings, the pipe-fish, and 
other interesting objects safe into their glass compartments, and he will tell us of specially constructed tanks for railway transit, and innumerable devices for keeping the water cool and aërated, and watchful care and foresight in every step of the process. He will tell us of failures arising from the omission of some trifling detail, unforeseen or thought unimportant; but he can never tell us of lucky successes or triumphs easily won. Each detail was thought out beforehand, and carefully planned in accordance with all that was known of the necessary physical conditions, and even failure sometimes taught as much as success.

If, then, the vitality of a fish just taken from the sea needs such careful conservation, how much fostering should the embryonic vital spark in the ovum demand? Salmon ova are, perhaps, exceptionally delicate, as is well known to all breeders; but the writer must confess himself astonished at their extreme sensibility to injury when Mr. Robert Ramsbottom, of Clitheroe, 
told him that on one occasion he was carrying three soda-water bottles, containing fertilised ova, slung in a handkerchief, to prevent even the concussion arising from the motion of his body in walking, when one of the bottles slipped from his hand and fell upon the earth. The result was that not a single ovum in that bottle hatched, though they were treated exactly in the same manner as the rest of the batch from the same fish-fertilised at the same time with milt of the same male-which did well. After this the writer was prepared to believe that the task of conveying them to Australia was hopeless, with this, among many more obvious and serious difficulties, to be overcome.

The idea of transporting the young fry seems never to have been seriously entertained-at least it was never tried. A ship specially constructed could not have carried enough water, nor could it be kept in proper condition to supply the fish with a constant stream for three months, and the continual and often violent movement in 
the troughs would probably have killed them in a few days. The first attempt made was in 1852, by a Mr. Boccius, and he not only decided on making his trial with the ova, but was conscious of the importance of protecting them from mechanical injury. Failure in this point alone has been the primary cause of disappointment in several otherwise promising shipments, until Mr. James A. Youl devised a simple plan which has never entirely failed, and in some instances has proved so successful that we may fairly regard it as the principal instrument in solving the most difficult problem in acclimatisation yet encountered, the influence of which on pisciculture we cannot yet fully estimate. Mr. Boccius' attempt to transmit the ova to Tasmania, though it cost him $\$ 300$, failed from two causes. In the first place, he did not succeed in shielding them from injury, and in the second, he had no provision for keeping the temperature low enough. In each mesh of a gutta-percha sieve a single ovum was placed, and the sieve fixed in the 
horizontal section of a wooden tub. The whole apparatus was immersed in water, which was changed every six hours; but none of the ova reached the tropics alive.

\section{MR. YOUL'S EXPERIMENTS.}

Reflecting on this experiment, Mr. Youl set to work in 1854 to study the whole subject of the artificial propagation of salmon and the transport of their ova, and he came to the conclusion that the governing principle must be retardation of the development of the embryos beyond the average natural period, if this could be effected without destroying them. Experiments made at the Crystal Palace, in a suitable breeding-place, had proved that they may hatch at any time between thirty-five days and 140 days from the date of fertilisation, but that the extreme limit was most dangerous. This wide range, of course, depended upon temperature, and the two extremes represent the highest and lowest temperature that they will endure while pre- 
serving their vitality. It may not safely be raised above $50^{\circ}$ nor let below $35^{\circ} \mathrm{Fahr}$., while the freezing-point is most probably fatal. No hope was held out by the most experienced pisciculturists; and even Mr. R. Ramsbottom, whose skill and care in supplying ova in the best possible condition has been conspicuous, and who has taken genuine interest in all the experiments, thus expressed himself in a letter to Mr. Youl: "You might as well try to fetch Australia to England as to carry spawn to it in moss. Salmon spawn must be either hatching or dying from the moment it leaves the fish; you can retard it to about 140 days by a low temperature, but no longer. Neither one man nor another can carry living ova to Australia in any way; you can send young fish, that is all." This represented the best opinion an expert could give at that time, and was based on existing experience; but the writer heard Mr. Ramsbottom on a subsequent occasion (when he brought the ova down to the East India Docks in January, 1873, for shipment in the Oberon to 
New Zealand) declare his unqualified satisfaction at the success of a method which he had formerly looked upon as impracticable.

The experiments made at the Crystal Palace were of considerable importance in deciding the question whether the ova could be retarded long enough to enable them to arrive at the end of the voyage unhatched. The young fish must break from the investing membrane in water if it is to survive, and no provision for this could be adequately made. on the ship. Hence its liberation must be suspended until it could be placed in the waters of the colony. Mr. Edward Wilson, president of the Victorian Acclimatisation Society, associated himself with Mr. Youl and some influential colonists in raising a subscription of about $£ 600$ for a trial, which was to be conducted solely by Mr. Youl, and this was the beginning of a series of systematic efforts. Mr. R. Ramsbottom collected 30,000 ova from the Dovey, and they were shipped in the $S$. Curling from Liverpool on February 25, 1860. The plan of shipment 
was briefly this: The ice-house consisted of two rooms, one within the other, lined with lead, having an interspace of seven inches filled with powdered charcoal as a non-conductor, and fitted with drain pipes to carry off to the bilge the water from the melting ice. A water tank was erected over the ice-house with a pipe leading into and passing twice round it, emerging above the place devoted to the ova, and allowing a gentle and continuous stream of water to pass over them as they lay on gravel in swing trays with an incline of $2 \frac{1}{2}$ in. to the foot, thus simulating, as far as possible, natural conditions. The shipment was committed to the charge of Mr. Black, whose care in removing dead ova and otherwise attending to his duties was unremitting; but the passage was long, the fifteen tons of ice melted rapidly, the ova were no doubt knocked about in consequence, and the last of them was found to be dead when the ship had been sixtyeight days out, in lat. S. $29^{\circ} 52^{\prime}$, long. W. $27^{\circ} 38^{\prime}$, the temperature then being $75^{\circ}$ 
Fahr. Mr. Black's journal was submitted to Mr. Brady, of the Irish Salmon Commission, and Mr. R. Ramsbottom, who came to the conclusion that the disturbance of the ova for removal of those which were dead-a perhaps necessary operation in the circumstances-and the violence they must have encountered, were the chief causes of failure.

It is easy enough now to point out defects in this experiment. All it taught then was that a larger supply of ice and more effectual protection against motion among the ova must be provided. Private enterprise had furnished both the funds and the work, but now the governments of Tasmania, Victoria, and Southland (N.Z.), convinced of the practicability of the undertaking, voted $£ 3000, £ 500$, and $£ 200$ respectively, and delegated the conduct of the work to Mr. Youl. This was, in its way, a handsome acknowledgment of the efforts of those who had gone so far, and an expression of confidence in their ability to land living ova in Australia; for no one 
had yet succeeded in carrying them alive thirty degrees south of the equator; and there could be no doubt of the possibility of guarding against the causes of their destruction at that point. An active body of acclimatisers in Tasmania undertook to construct hatching boxes and breeding ponds on the banks of the river Plenty, an affluent of the Derwent, and the government liberally provided the funds. The physical conditions were more favourable perhaps than in any other of the colonies, and this was to be the centre of distribution for all, as it has actually proved. A sketch of this establishment may not be unwelcome to those who have begun to appreciate the difficulties connected with this endeavour to acclimatise the salmon family.

The estuary of the Derwent is indented with innumerable bays swarming with the small fry of native fish, crustacea, and other suitable food. At the head of the tributaries of the Derwent are lakes 3000 feet above the sea level, affording a constant supply of cool water. In the month of July, the 
spawning time of the naturalised fish, the temperature of the water is about $44^{\circ} \mathrm{Fahr}$. at a point far below the probable spawning grounds, while some miles higher up this temperature will be maintained for a long time. The fish thus have a range of many miles of ground favourable in every respect for the deposition of their ova. The river was, of course, selected on account, among other reasons, of its inaccessibility to the net of the poacher, its snags and rocks being its best keepers, and its deepest pools having perpendicular banks. No net would have a chance, and the most skilful angler a very poor one, in this secure nursery for colonial salmon. For many miles a swift, clear, and deep stream runs through primary rocks, and there are in the upper waters broad stretches of coarse sand for nesting. There are neither locks, weirs, nor other obstructions, and pollution cannot become a question for centuries. Amid the grand scenery of the head waters of the river it is easier to imagine one's self in Scotland or Norway than at the Antipodes. 
No native predatory fish exist above the influence of the tide. In the estuary the shark is abundant enough, but he is not likely to be able to capture so powerful and active a fish as Salmo, and the cormorant and darter are being exterminated-albeit more than once promising young salmonids have been taken from the maws of these birds.

Beside the foresight shown in selecting this river, the Salmon Commissioners acquired ample powers for protecting the newcomers, and nothing has been omitted from the Salmon Act of 1865 which could secure the safety of the valuable importation.

Before committing himself to the large expenditure of public funds which would be involved in the next venture, and feeling his responsibility as its director, Mr. Youl visited breeding establishments in Scotland and Ireland, to make himself familiar with the best methods of treating the ova and rearing the young fish, and, armed with introductions to Mr. Geoffry St. Hilaire and M. Coste, examined the plans adopted 
in France. M. Girley showed him how the ova of various species of fish were sent long journeys, packed in wet moss in earthenware jars covered with perforated parchment; but he was told on all hands that they would not travel unless so far advanced towards hatching as to exhibit the eye, and could in no case be sent to Australia. It will be seen subsequently that Mr. Youl's experience was diametrically opposed to this, and that the sooner the ova were packed and started on their journey after fecundation the better were the results. But he could not adopt the French plan, for the obvious reason that ova so far advanced would be hatched in three weeks, and what was to be done with them as young fry at sea? There was nothing for it but to again try the effect of placing them on gravel beneath a stream of pure water, cooled by passing through the ice-house. Shipowners appear to have contracted an absurd fear of a cargo of several tons of ice; and, after great trouble, a small steamer, the Beautiful Star, was chartered, and in 
five weeks the apparatus was fitted up. It was a distinct improvement on the former, but as it was discarded in the finally successful case, its principal features need only be noticed. One set of trays, containing ova laid on gravel, was hung on gimbals, and another large swing tray contained the remainder. A constant supply of water was made to flow orer these at the rate of 500 gallons a day, with power to increase the quantity to 2000 gallons by means of a force-pump, and the whole body of water could be changed every fourth day. The ova were expected to hatch on board ship, and it was at least hoped that the supply of water would last long enough. Cumbersome as the apparatus was, it was the best that could be devised at the time; but Mr. Youl determined to make an experiment which, since it practically solved the problem of exporting the ova safely, is of the highest importance. A pinewood box, an inch thick and about 11 in. by 8 in. by 6 in., perforated at top, bottom, and sides, to allow the free passage of water, was imbedded in 
the mass of the ice, and three hundred ova were packed in living moss in it. The principle of this was to retard development by means of the passage of ice-water through the box, and it would not be touched until the end of the voyage. The ship was started. on March 4, 1862, with 80,000 'salmon ova, taken chiefly from the Dovey by Mr. R. Ramsbottom, whose son was sent in charge; but the heat of the tropics was so great that, in spite of his unremitting attention, the ice melted rapidly and was all gone by May 17, in lat. S. $22^{\circ} 19^{\prime}$, long. W. $25^{\circ} 55^{\prime}$, when the temperature of the water was $59^{\circ}$. The ova in the box survived eight hours after the death of all the others in a temperature of $65^{\circ}$; and, had the ice lasted, there can be little doubt that these ova would have lived to the end of the voyage, and might have been successfully hatched in Tasmania.

Much disappointment was, of course, felt by those who had watched the result of this shipment with anxious and perhaps too sanguine expectation. The preparation of 
the ponds in Tasmania for the expected salmon and this experiment together had cost $£ 1410$, and though Mr. Youl had given his time and had besides contributed $£ 200$ in perfecting details of which the commissioners perhaps would not have seen the necessity, he was abused by the majority of the colonists and the colonial press, and accused of having wasted the public funds on a crochet. It is almost incredible that a press with the smallest claim to intelligence could have talked the rubbish to be found in its columns at that time, with one or two exceptions. It is evident from the report of the commissioners that some dissatisfaction was felt even among them, but they did not point out what more might have been done, or what error had been made, and they failed signally to remark the significance of the box of ova which had outlasted the others. But here was the germ of the principle of treatment which ultimately led to success, and it made an impression on its author, Mr. Youl, which he was not likely to disregard; but he had 
decided to work in future with private means rather than incur further obloquy.

The colonists did not reflect that, having placed their funds in the hands of a particular person, and having besides given him their entire confidence, they were not entitled to complain of failure; but they stultified themselves completely by their censure, as unjust as it was ungenerous and illogical. Mr. Youl had held out no extravagant promises, nor professed overweening reliance on himself; he undertook to do his best towards the solution of a problem of which no man then held the key, and an examination of the account shows that every item of expenditure was carefully considered and well warranted.

In consequence probably, however, of the energetic advocacy of the chairman of the commissioners, Sir Robert Officer, and a few others who appreciated the difficulties of the task and saw how nearly they had been mastered, the Tasmanian government gave the conduct of another trial to the Australian associations, who in turn handed over 
the responsibility to $\mathrm{Mr}$. Youl, which he accepted on condition that he should have supreme authority.

Convinced that there was yet much to learn, Mr. Youl set about a series of experiments designed to test the vitality of salmon ova at a low temperature, and for this purpose the Wenham Lake Ice Company allowed space in one of their vaults. It is: important to give the details of this, because it elicited three heretofore unknown factsfirst, that a continuous and full stream of water is not essential to the preservation of vitality; second, that partial deprivation of air is not fatal ; third, that light is not necessary. On the 17th of January, 1863, 5000 salmon ova were obtained from a female and fertilised by the milt of one male. From 200 to 600 ova were placed in each of eleven wooden boxes, filled with moss taken from one locality and distributed carefully among it. Seven of these were covered with blocks. of ice some $2 \mathrm{ft}$. thick, and the whole buried under $2 \mathrm{ft}$. of sawdust. Few believed that a single ovim would be found alive at 
the end of sixty-seven days, but when some of the boxes were opened in the presence of a number of practical and scientific men, the microscope showed the great majority of the ova to be alive and healthy, though there was neither air, light, nor a continuous supply of water. Some boxes were allowed to remain for one hundred and twenty days, and still the ova were healthy and the moss growing. The temperature had been about $32^{\circ}$ the whole time. From both sets of boxes a fair proportion were afterwards hatched out. Still more remarkable than this was the case of one box placed in the dry compartment of a patent refrigerator surrounded by ice and proved to be air-tight by inclosing in it a lighted candle, which went out soon after the lid was shut. On the ninetieth day this box was opened, the moss was damp though the outside was dry, and no less than seventy per cent. of these ova were hatched. But by far the best results were obtained from a box in the ice compartment of the refrigerator, with blocks of ice (renewed as they melted) piled upon 
it, the water being allowed to percolate through it. Of these ova the extraordinary number of ninety-nine per cent. produced healthy fish after they had been under this treatment ninety days! Two more boxes were somewhat differently treated, and this was essentially the method adopted in all future shipments. They were covered and surrounded by blocks of ice, and consequently were not entirely deprived of air, and, of course, received the cooled water from the melting ice. In one of these boxes the moss was still green and living, and the ova were healthy; but in the other the moss had been attacked by a fungus, which had extended to the ova and destroyed many of them. The conclusion arrived at was that neither light nor a large supply of water was necessary to the vitality of salmon ova, that retardation could be safely carried to a hundred days, and that moss, with the roots attached, would continue to grow under these singular conditions, and assist, both directly and indirectly, in maintaining the health of the ova. 
The reader will have no difficulty in estimating how far these experiments, devised solely and carried out by Mr. Youl, advanced existing knowledge. Commenting, in their report for the year 1864, on the success of the method which had then been proved, the Tasmanian Commissioners say: "The result of these experiments constitutes one of the most valuable discoveries yet made in the art of pisciculture, and must ever indicate an important era in its history."

THE FIRST SUCCESSFUL SHIPMENT IN 1864.

Mr. Youl had persistently asked questions of nature by direct experiment, and had received trustworthy answers, on which he fully relied for the conduct of the next trial, and now for the first time he felt assured of success, and it must be admitted that he deserved it. He saw that there was nothing to prevent the arrival of living ova in Tasmania if a sufficient stock of ice could be preserved throughout the voyage, and to 
this point his attention was particularly directed. In January, 1864, just at the most suitable time, Messrs. Money Wigram and Sons offered a space of fifty tons by measurement in their fine ship the Norfolk, declining the hundred guineas which $\mathrm{Mr}$. Youl had offered them on his own account in discharge of the freight, and wishing this. to be their contribution to an undertaking of so much scientific interest and commercial value. The ice-house was built upon much the same plan as in former shipments, but the swing trays and supply pipes were abolished. The ova were to receive no. other supply but that from the melting ice, and provision was made for thorough drainage. It was not to be opened until their arrival, and they were enclosed and sealed up in it, so that whatever the fate of the plan of non-intervention might be, it would be rigidly carried out. External air of a high temperature would be excluded, and some parts, at least, of this twenty-five tons of Wenham Lake ice might arrive unmelted. The packing of the ova was done in 
the following manner. I describe it from personal observation, having assisted in packing a subsequent consignment with $\mathrm{Mr}$. Youl by the Oberon, in January, 1873, in which the method was the same as that employed in 1864. The box to contain the ova was of inch pine, measuringabout 12 in. by 8 in. by 5 in., perforated on top, bottom, and sides. At the bottom was first spread a layer of charcoal, in small lumps; next a layer of broken ice; then a nest of fresh, carefully washed, living moss, with the roots attached, and on this springy cushion were distributed the ova from a wide-mouthed bottle half full of water, and in such a manner as to obviate contact with one another as far as possible. Over them was lightly laid a covering of moss, then a double handful of broken ice, and the whole was saturated with ice water, and screwed down. One hundred and eighty-one of these boxes, containing 100,000 salmon and 3000 trout ova (S. fario) were packed closely on the floor of the ice-house, and upon them were piled cubical blocks of ice to the height 
of $9 \mathrm{ft}$. Nothing could prevent the wasting of the ice, but the ova would get the benefit of it as long as it lasted. They would rest as securely as might be on their mossy bed, the charcoal would absorb the gases of decomposition, and the living moss would probably give out some little oxygen for their benefit. Mr. W. Ramsbottom took charge of the consignment; the vessel sailed on the 21st of January, 1864, and arrived at Melbourne on the 15th of April, where the ice-house was first opened, and, to the intense satisfaction of all concerned, three-fourths of the ice was intact, and a very large proportion of the ova in a box tested found to be in splendid condition.

The problem was then solved. After years of trial and failure and patient experiment, living salmon ova had been landed in Australia. The colony of Melbourne retained about 4000 salmon ova (of which 400 were afterwards hatched), and the rest, with the trout intended by $\mathrm{Mr}$. Youl to be left at Melbourne, were sent on to Hobart Town by a government steamer secured for the 
purpose by the late Mr. Edward Wilson, then president of the Acclimatisation Society of Victoria, who had from the first evinced the utmost interest and activity in everything connected with the subject, and had expressed his confidence in Mr. Youl's ultimate success.

The first act in the drama, then, had been brought to a successful conclusion, and in April, 1864, living salmon and trout ova were on their way to the breeding ponds on the Plenty river in Tasmania. They were taken as fast as steam could bear them to the head waters of the Derwent, and the boxes were there packed in cases wrapped. in blankets with part of the remaining ice, slung on bamboo poles, and carried by a force of forty bearers over four miles of rough country to the nursery provided for these interesting colonists. The Salmon Commissioners had prepared troughs with gravel at the bottom, and the layers of moss being gently taken from the boxes and laid in the troughs, the flowing water soon lifted the ova, and deposited them on the gravel, 
when the dead were picked out. The utmost care was exercised in these delicate operations by Messrs. W. Ramsbottom and Allport, and they estimated that 30,000 ova, of which 300 were trout, were living, but of these perhaps 16,000 were unfertilised; and, though they had maintained their brilliancy for so long a time, and were even then probably capable of fertilisation had any milt been at hand, the embryonic spot never appeared in them. It is worth while to remark that in proportion as the moss was green and fresh the ova were in good condition, and wherever it was dead the mortality was greatest. The remaining ice was made the most of by placing it in tubs and allowing the stream to flow through it, and then into the troughs. Ninety-one days from their embarkation the bulk of the ova were laid in the waters of the Plenty, but some were set apart as a test for the extreme limit of possible retardation, and these were a hundred and thirty-six days old when immersed. Only two or three. fry were hatched from this lot, although the 
form of the young fish could be traced in almost all of them. We may, then, safely assume the correctness of Mr. Youl's opinion, deduced from the trials in the ice vaults, that the nearer the fish is to extrusion from the egg, the more critical is its state, and that a hundred days before immersion in'running water cannot be safely exceeded.

THE FIRST SALMON IN TASMANIA.

Act the second was completed on the 4th of May, 1864, when the first trout emerged from the egg, and on the following day the first salmon, which had ever yet swum in the southern hemisphere, and by May 25th there were two hundred healthy young trout, and by June 8th "several thousands," as the commissioners' report says, of salmon sporting in their new home, enjoying their rations of boiled liver morning and evening, and affording a living testimony to the perseverance and scientific foresight of one who had laboured for 
ten years single-handed at a problem in acclimatisation which both scientific and practical men had often declared to be insoluble.

The treatment of the young fish was essentially the same as that adopted in the establishments in Scotland, and all local enemies were watched for and destroyed. Knowing the rapacity of trout, Mr. Youl had advised that they should not be placed in the same river as the salmon, because, assuming that the latter went away to the sea and returned to breed, there would be numbers of well-grown trout in the fresh waters ready to attack the young salmon fry. By some neglect, however, the trout did escape into the Derwent, and they have probably done much damage, for many of them had grown into large fish in a couple of years, and one which was taken four years only after importation scaled $9 \frac{1}{4}$ lbs. ! and the river now contains thousands of heavy trout, much to the delight of the Tasmanian fly fisher. The health of the growing parr was excellent, and they were 
watched with pride by visitors to the ponds, and talked about in society as the lions of the season. Individually they exhibited considerable difference in size and development, but in October, 1865, they had nearly all put on their smolt dress, and showed much uneasiness in their fresh-water prison. Accordingly, the grating was raised, the last act in the drama played, and two thousand splendid young salmon were despatched on their perilous journey to the sea.

It would be unjust to omit mention of the contributors to the precious cargo of the Norfolk. Mr. Youl had asked for the co-operation of owners of salmon rivers in supplying ova, and the proprietors of fisheries on the Tyne, Tweed, Severn, Ribble, Ettrick, \&c., responded heartily. In the early part of the year a strong frost had prevented the salmon from gaining their spawning grounds, so that up to January 18th no ova had been sent to London; but on that day a sufficient supply arrived from different parts of the comntry, and in three days the packing was done and the ship 
sailed. Almost at the last moment Messrs. Francis Francis and Frank Buckland sent the three thousand trout ova to the docks. Admiral Keppel requested Mr. Buckland to collect some ova from the preserves of the former on the Itchin, and forward them as a present from him to Mr. Youl. Mr. Francis Francis also sent two lots, one from Mr. Spicer's mill at Alton, on the Wey, and another from Mr. Thurlow's mill at High Wycombe, Bucks, which were all packed by Mr. Youl in the same way as the salmon ova. But though this valuable present has stocked the Tasmanian and New Zealand streams, the official reports make no recognition of it, while praise and thanks were bestowed upon some who, however well they did their duty, were paid for their services. But for the energy of these gentlemen in collecting the trout ova at a time when it must have been no easy task, there would have been no trout at this moment at the Antipodes; for no subsequent shipment of trout ova has been successful. Although a parcel of about 
1500, sent by Mr. Charles C. Capel in 1878, were reported to have arrived at Wallace Town, New Zealand, in excellent condition, their ultimate fate is unknown, even to Mr. Capel himself. The whole cost of the Norfolk shipment was about $£ 700$, and the colonists cannot consider that a high price for the result-two thousand salmon and an unlimited stock of trout, to which must be added the breeding ponds in Tasmania. Each of the colonial legislatures has done Mr. Youl the justice at least to record its sense of the value of his services, and confidence being now established in his method, he was naturally looked to as the only man competent to undertake any future shipments that might be thought necessary.

It would have been unwise to trust entirely to the two thousand salmon smolts already spread over the wide estuary and bays of the Derwent for stocking that or other rivers of the island. So small a number might be fatally reduced by enemies at sea, and possibly not a single pair might 
return to the river. So little is known of the habits and food of the salmon in salt water, that nothing could be said of the probability that any of these young fish would find their way to Australia or New Zealand. To reach any stream in Australia they must travel some three hundred miles, and the nearest in New Zealand would be about one thousand miles distant. They might be tempted to wander towards the cooler waters of the south, and take up their abode in a climate whose mean annual temperature is $10^{\circ} \mathrm{Fahr}$. lower than that of Victoria; but it would be necessary for them to cross a sea of great depth swarming with predatory fish. The Tamar and Esk, in Tasmania, might be discovered by some of them coasting the island in search of food, though the estuary of their own river, the Derwent, would presumably afford them an unbounded supply. In any case, however, this small body of fish had gone no one could tell whither; and it would have been supreme folly to trust to the chapter of accidents, or assume that in a few years 
their progeny would be numerous enough to stock even a single river in Tasmania, while Australia and New Zealand had still less prospect of seeing any immediate return for their contribution to the acclimatisation fund.

The colonists had now two thousand young salmon somewhere in the vast expanse of Tasmanian waters; and if they might reasonably hope that some of these, even a single pair, would survive to re-enter one of their rivers as grilse, there could be no certainty of this. We know that every year young salmon and salmon-trout stray from streams far away to the mouth of the Thames, and vainily seek to enter its polluted waters, in order to stock its long since untenanted and no longer "silver" streams with their beautiful progeny; but we also know that they find all round our coasts the crustacea, sand eels, and small fry in which they delight; for they have been with us ever since the prehistoric cave dwellers speared them in the river Vézère, and left them among the débris of their 
cookery to testify that that river, which now holds no salmon, then abounded with them. Indeed, these French troglodytes were judges of good fare, for they ate no. other fish but salmon. Thus the northern hemisphere has been the habitat of the family throughout the many alterations of level and changes of watershed which have taken place in tertiary times; but the deposits of the southern knew not their bones. nor the rivers their living presence until now, and it was altogether a subject for speculation whether they would find there suitable conditions of life.

SALMON-TROUT BREEDING IN CAPTIVITY.

Mr. Youl did not lose much time, and by the 20th January, 1866, the Lincolnshire sailed from London with a consignment of 87,000 salmon, 15,000 salmon-trout, and 500 brown trout ova, arriving in Melbourne. on the 30th April, whence they were at once sent on to Tasmania, and placed in the breeding ponds on the 5th May. The 
packing of the ova, the form of the icehouse, and all details of treatment were similar to those which had proved so successful in the Norfolk, but some of the circumstances were more favourable. Nearly two-thirds of the thirty tons of ice remained, the temperature of the ponds was lower, and experience had suggested many little improvements during the hatching; and though these eggs had been a hundred. and four days in the ice, 6000 young salmon and 900 salmon-trout were raised from the 30,000 living ova transferred to the ponds-a percentage which must be regarded as very satisfactory.

With the object of testing the question whether any migratory species of Salmo will breed in confinement, a number of these salmon-trout fry were put into a specially constructed pond, fed by a small rill of bright cool water, where they were disturbed as little as possible. By the middle of October, 1867, many of these prisoners had put on the smolt dress, and, no doubt feeling the migratory impulse, 
leaped upon the bank in some numbers and perished. In May, 1869, the water in their inclosure was lowered, and twelve fish, weighing from half a pound to considerably more than a pound each, and of fine silvery hue, were seen-all of them having lost the juvenile markings. These, in fact, were mature fish, for in July of the same year they spawned in the ponds, and in the following December five hundred fry hatched from their own ova were turned into the river Huon. This statement was received at the time in Europe with incredulity, and even ridicule. A migratory salmonid remaining and perfecting its ova and milt in fresh water, and proving abundantly fertile, too? Nonsense; the thing could not be : it was a hoax or a blunder! That it was no blunder should be evident when it is said that the parents of the original ova sent from England were procured, and the fertilisation effected, by the experienced hands of Mr. R. Ramsbottom, and if he did not know the migratory from the non-migratory species, no one in England could lay claim to such 
knowledge. The subject was discussed by portions of the press and private persons with amusing self-confidence and presumption, and a great deal of ink was spent in discussions chiefly remarkable for bad natural history. Sir Robert Officer, chairman of the Salmon Fisheries Commission, and Mr. Morton Allport, both familiar with the characters and habits of the salmon family, paid great attention to the behaviour of the imprisoned salmon-trout, and here are their ipsissima verba, from the official report, dated September 2, 1869: "In April last it was discovered that some of the fish were gravid with spawn, and on the 25th of June the first pair began to form nests and deposit and fructify their ova in the small rill attached to their pond. Other pairs soon began the same operation, and the process was complete about the end of July - the Tásmanian mid-winter, it must be recollected-resulting in the production of several thousand healthy ova." This is incontrovertible, and it may be added that it has taken place each successive year since, 
and thousands of young fry have been distributed to other rivers. This is probably the first and only instance in which a migratory salmonid has proved fertile without having been to the sea. There is some, though perhaps not conclusive, evidence that Salmo salar have also bred in these ponds, and it amounts to this: two young specimens bred there were sent to England for Dr. Günther's opinion, and he was fully informed of their origin, and, while reluctant to express a decided opinion that they were true salmon, he said that they presented all the anatomical characteristics of that species. It is quite likely that some of the salmon fry found their way into the salmon-trout pond unobserved, for the inclosures appear to have been separated only by a grating with a common supply of water from the river.

Dr. Günther refers in the "Catalogue of British Fishes" to the experiments made in Wales, and says that the evidence that the young fish made use of were of a migratory species, or that the full-grown fish 
were the same as those originally confined, was most unsatisfactory; and we know what contemptible tricks have been played; and that in two cases he examined, the salmon and pure sewin died when not allowed to go to sea, though the hybrids between the sewin and trout survived, but were all barren. The Tasmanian case, on the other hand, was perfectly clear. There could be no mistake about the species and none that the fish which spawned were the same as those secluded in May, 1866; and those who have practical experience of the delicate character of all operations in pisciculture will appreciate the care and attention which must have been bestowed on these prisoners, rendering their lot so happy that as soon as they became sexually mature they set about the most critical and important business of their lives, that of continuing their species. The commissioners were right in regarding this as a hopeful sign for the free fish in the river. If the captives found their new home so comfortable, the others, as far as food, temperature, 
and the quality of the water were concerned, could not fail to be equally well satisfied, and ascending fish began to be eagerly looked for. Some of the descending smolts, it is known, were captured in the brackish water, and probably many others besides were quietly "burked" by the fishermen, who all along have endeavoured to destroy evidence of the success of the attempt to acclimatise the salmon, because they were put under some restrictions against scraping the river at all times and seasons with their nets. They could not apparently give up for a few days in the year their systematic efforts to exterminate the native fish, in order that they might one day have a far greater source of profit in the salmon; and a little judicious bribery revealed an organised system of murder of all strangers found in the river.

The fertility of the imprisoned salmontrout seems to have been exceptional, for every one of the 142 ova sent to the Otago Acclimatisation Society produced a fish. In July, 1870, they were again busy spawning, 
and in November they had attained a weight of from $2 \mathrm{lbs}$. to $3 \mathrm{lbs}$, and were bright, handsome fish of perfect symmetry. In an adjoining pond were 350 of their smolt progeny ready to be released, and in a small rill thousands of young fry of that season. These fish were not' so large as they probably would have been had they spent some months in the sea, but they were thoroughly healthy, and confinement had not diminished their fecundity.

It was observed that some of the salmon from the Lincolnshire put on their smolt dress in October, 1868, or when they were akout seventeen months old, and others not till the same month in the following year, which is the case, too, at the Stormontfield establishment; so that the period of infantile development is much the same at opposite sides of the globe.

SALMON FOR NEW ZEALAND.

We may now pass rapidly over subsequent shipments. The Celestial Queen sailed for 
Otago, New Zealand, in January, 1868, with a total of 150,000 salmon and brown trout ova under the charge of Mr. Dawbin; but the passage was long, ice formed in the hatching-troughs on the Molyneux and nipped the young fry to death at the moment of its extrusion, consequently, not, one trout was produced, and only five hundred salmon, which were turned into the river in November, 1869. The Mindora shipment at the end of the year fared no better, for the 110,000 salmon and 500 salmon-trout eggs sent out had been about 135 days from the parent fish before they were placed in the water, so long had the ship been at sea, and all perished. There are one or two features of interest in connection with this. A living snail, a worm, and a wasp were found among the moss, and "acclimatised;" two of a number of oysters sent lived, and were placed on a bank in Portobello Harbour; some gudgeon and carp for the colony died before they reached the tropics, and a few tench, which were healthy and likely to live, were thrown overboard by 
a careless sailor. The shipments to New Zealand had been discouraging, no doubt, but the inferiority of accommodation for the ova and young fish, in comparison with that in Tasmania, must be taken into consideration.

However, in January, 1873, another consignment was made to Otago, New Zealand, in the Oberon, of about 150,000 ova collected from Fingland, Scotland, and Ireland, and fertilised by those who carried out this part of the operation on former occasions, and among these many presented the yellow colour of death, but the lot was of average quality. I was present during the greater part of the time the packing was done by Mr. Youl, and had an opportunity of seeing the extreme care and attention bestowed apon every detail. The weather was exceptionally warm, and it is probable that the organic changes in the ovum towards development, which take place about three days after fertilisation, had already begun, and the sudden change from the temperature of the air at $50^{\circ} \mathrm{Fahr}$. to that of the ice- 
house at about $35^{\circ}$, would at least be a severe trial, if not absolutely fatal. One lot of these ova contained a much larger proportion of dead than the remainder, owing, Mr. Ramsbottom informed me, to the fish from which they were taken making a severe struggle while being stripped of its burden. About six hundred fish were hatched from this large consignment. The funds for all the shipments to New Zealand were contributed by its various provincial governments and acclimatisation societies; and, as in all other cases, Mr. Youl's time and experience were freely given, and many minor expenses besides defrayed by himself. The ice-houses were constructed under his supervision, and all the ova packed by his own hands, with the exception of a few boxes manipulated by visitors and his subordinates when the bulk of the work was finished. $\mathrm{He}$ never shrank from the drudgery of detail, but astonished onlookers by undertaking much fatiguing, manual labour in order to insure that it should be thoroughly well done. 
The following article from the Field of January 26, 1878, goes far to explain how matters were managed-

"The efforts made within the last fifteen years to acclimatise salmon in the Australasian colonies have now become of worldwide interest; and, while the colonists have set before themselves a very tangible material object, naturalists have been anxious for its realization on scientific grounds. The colonial officials charged with the direction of affairs after the ova have been delivered to them have not always justified the public confidence reposed in them by the colonists, who have a right to know whether or not the large sums voted for the acclimatisation of salmon in their rivers have been expended with the best judgment and with a single eye to the interest of the colony. Great credit is due, no doubt, to the Tasmanian commissioners for the ability and assiduity they have displayed in rearing the young fish, and in distributing both ova and fry to the neighbouring colonies, as may be 
gathered from the reports signed by Sir $R$. Officer and Mr. Morton Allport, on whom the burden of this work has fallen. Had the like knowledge of the subject and interest in the success of the experiment prevailed with the New Zealand officials, the latter colony would probably now have been the head-quarters of the salmon at the Antipodes; but the grand opportunity was allowed to pass, under circumstances with which the colonists should be made ac- quainted, since they will not obtain the information from the official reports.

"In January, 1869, the Celestial Queen sailed for Otago, New Zealand, with 150,000 salmon and brown trout ova, packed by $\mathrm{Mr}$. James A. Youl, C.M.G., on his now wellknown plan, and were placed under the care of Mr. R. Dawbin, who was to superintend the rearing of the fry at the newly constructed ponds on the river Wiwera, a suitable tributary of the Molyneux. The construction of these ponds, of which we have seen a plan, was excellent, and, together with the manager's house, cost 
about 22000 . There was, however, one defect. The hatching boxes were not water-tight; consequently, when it was necessary to shut off the turbid water coming down in a fresh, the reservoirs containing bright water were unable to supply the loss in the boxes, and the ova would soon be left dry. To remedy this when the ova arrived would have involved great loss of time, and would have endangered the whole consignment. Mr. Dawbin was therefore obliged to use the imperfect boxes, and make the best of them. From twenty thousand to thirty thousand healthy ova had been deposited on the gravel, in the boxes, and all promised well. When about five hundred fine young fry had come out, a fresh set in, and lasted so long that the reservoirs could not maintain the waste through the leaky boxes, and $\mathrm{Mr}$. Dawbin was compelled to let in the flood water, in order to keep life in the ova and fry. The filter became choked with the river sediments, and a layer of fine mud settled down on the ova in the boxes. In 
spite of every attention, thenceforth not a single ovum hatched, though the fry survived, and the colony thus lost probably twenty thousand salmon. When about thirteen months old the young fish began to exhibit great restlessness, and three of them leaped ashore and perished; these, now in the Otago Museum, measured respectively $10 \frac{1}{2}$ in., $11 \frac{1}{2}$ in., and 12 in., and were all finely grown, bright, handsome fish, ready to go to sea. Mr. Dawbin at once wrote to the officials to come and see the liberation of these fish, but advising that some should be retained to breed in captivity, as had been done in the case of the migratory salmonids introduced into Tasmania. A day was appointed, but they did not come, and they subsequently authorised him to let the fish go, retaining, however, some of them. The ponds were carefully examined, the water lowered, and a splendid shoal of about five hundred observed, with not a dead one anywhere. Of these eighty were retained, the rest. being sent to find their way to the sea. 
through the waters of the Molyneux. Numbers of visitors had been from time to time to see the fish, which fed freely in their presence. In anticipation of the breeding time, the rill leading from the river was laid down with water-worn gravel, previously boiled, and the fish placed in possession. Not one of those could have been more than fifteen months old, and they ranged from twelve inches to fifteen inches-a fact , which pisciculturists will appreciate-and were fully satisfied with their new quarters.

"At this point the commissioners informed Mr. Dawbin that his services would be no longer needed, they having appointed a gentleman who seems to have had some influence with the Government, and on whose lands the ponds were situated, but was totally ignorant of the treatment the fish would need. Mr. Dawbin's offer to continue his services gratuitously for a term of six months was refused, and he was instructed to hand over his charge to the new-comer. This was too much for one 
who had devoted his time day and night for fifteen months to the care of the fish! The new-comer's incapacity would almost inevitably have resulted in their destruction; or, if this had not happened, he would have claimed whatever success might accrue. Impressed with the conviction that he was doing the best thing possible in the circumstances for the colony, Mr. Dawbin chose a night when a slight fresh was coming down, opened the gratings, and allowed the prisoners to escape into the river. It is not our province to defend Mr. Dawbin, but we would ask the commissioners why the circumstances which led up to this are suppressed in their reports, and the colonists whether they approve of the arbitrary substitution of an inexperienced manager for one who had abundantly proved his ability and deserved public confidence? Since the above erents the magnificent breeding ponds on the Wiwera have gone to ruin, as we are informed!"

The facts in the above article have never been challenged. 
The following description of the shipment by the Oberon is taken from an article in the Field of January 18, 1873-

"We had an opportunity, through the kindness of Mr. J.A. Youl, of being present, on the 14th inst., at the East India Docks, together with several gentlemen interested in the subject, to witness the packing of a large consignment of salmon ova for Otago, New Zealand. There is no necessity to inform those among our readers who have any experience in pisciculture that the utmost care and delicacy are needed to protect these sensitive embryos from all kinds of violence on a journey to New Zealand; but the method by which this is effected may not be familiar even to persons very well informed on the treatment of salmon ova at home. It must be recollected that in the case of a voyage to $\mathrm{New}$ Zealand the ova have to pass some weeks in a place where the temperature would, unless provided against, be seldom below $90^{\circ} \mathrm{Fahr}$; and ten seconds of such a temperature would be fatal to every chance of landing ova alive at 
the other side of the globe. The principle involved in carrying ova such a distance is that of retarding the natural process of hatching. Ice, then, is the agent employed. But how is ice to be preserved on a journey, the greater part of which is performed in a temperature very much above, and not often much below, our summer heat? A description of the ice-house on board the Oberon, which will take out the present consignment of ova to Otago, will best answer that question. A space, whose internal dimensions are rather more than $13 \mathrm{ft}$. by $9 \mathrm{ft}$. by $8 \mathrm{ft}$., is enclosed by bulkheads a little abaft the foremast, and situated upon the hold of the vessel below the water line. This forms the ice-house, which is surrounded by a "skin" of powdered charcoal about one foot thick, as a non-conductor, and lined throughout with sheet lead. On the floor of the ice-house is a wooden grating to carry off all water from the melting ice, which, after passing through the grating, finds its way to the bilge of the vessel through small scuppers at each 
corner, the object being to exclude external and, therefore, hot air as much as possible. The boxes containing the ova cover the floor of the ice-house, fitting closely to one another. Upon these are piled cubic blocks of Wenham Lake ice, measuring about two feet, right up to the roof of the ice-house, leaving just space for another tier of boxes upon the top of the ice. The entrance to the ice chamber is closed by a very heavy lid with bevelled edges, covered with sheet lead, and made to jam tightly into the opening, and, when all is complete, covered with thick felt. What goes on in the icehouse during the voyage may be told in a few words. Nothing, of course, will prevent the ice from wasting slowly away. As it does so the water from it percolates through the boxes-perforated to allow of this-and escapes by the drains below, the upper tier of boxes sinking gradually with it. Thus they are always in contact with the ice. It is absolutely essential that a considerable quantity of ice should remain to the end of the voyage, both to keep down the tempe- 
rature and to pack the boxes in which they are being taken to the hatching ponds after arrival. About twenty-five tons will be packed in the ice-house of the Oberon; and if she makes her passage in ninety days, there is every probability that a few tons will remain unmelted, and that some thousands of ova will survive to produce young salmon in New Zealand waters. It is, perhaps, needless to observe that this icehouse will never be opened on the voyage.

"The actual packing of the ova is done in the following manner: The box, made of pine, is about 12 in. long, 8 in. wide, and $5 \frac{1}{2}$ in. deep, and sufficiently strong to support the weight of the ice. On the bottom is distributed a layer of charcoal in small lumps, free from dust, over which a handful of broken ice is spread. A nest of fresh living moss, with the roots attached, is next lightly packed over the charcoal and ice. Upon this the ova are distributed as regularly as possible by pouring them out of a wide-mouthed bottle, with care to avoid injury. A second layer of moss is then laid 
lightly upon the ova, and the whole is saturated with cold water. Finally, a layer of broken ice tops the whole, the lid is screwed down, and the box taken off immediately to the ice-house. Simple as this process appears to be, it is incredible how many small details are involved in it; and if it is not done with most careful manipirlation, the chance of survival for the ova is small. Long practice has made $\mathrm{Mr}$. Youl an adept in the art of giving those nice touches to the materials which our unaccustomed hands failed to attain with the two boxes we attempted to pack. The object of the charcoal at the bottom of the boxes is to absorb any carbonic acid gas evolved from the decomposition of dead ova; the moss prevents motion among the ova, and gives them a soft bed, while it also assists in taking up the products of decomposition and furnishes at the same time a small supply of oxygen. Thus we have within the ice living vegetable organisms, with animal bodies whose life is in suspension, each feeding the other with that which 
it specially needs. Regarding the motion to which the boxes must be subjected in a gale of wind when the ice has melted and become loose in the ice-house, it is astonishing that any ova should survive. We can only account for it by the protection afforded by the moss, in which they lie on a springy cushion. So great is their sensitiveness to friction or concussion, that if water even is not poured carefully upon them they are killed. Mr. Ramsbottom, of Clitheroe, who has supplied the ova for the Oberon shipment, gave us an instance of the fatal effects of concussion. On one occasion he was carrying three soda-water bottles full of ova in water, wrapped in a handkerchief, and one bottle chanced to slip out and fall upon the ground. He did not rear one fish from the contents of that bottle!

"The ova have been taken from the Ribble and brought to London in excellent condition by Mr. Ramsbottom, though the yellow colour of death may be seen among them here and there, as is inevitable under the 
most careful management. Probably not less than 80,000 ova will go out by the Oberon; and, as these have all been packed by Mr. Youl's experienced hands, there is the best possible prospect of their safe arrival. Great expense is entailed as a matter of course. In the first place, the building of the ice-house, the boxes, and collection of the ova are no inconsiderable items; the ice will cost $£ 100$, and space for the ice-house more than half as much more. The cost will be borne by the New Zealand Government. None of the arrangements differ in any essential particular from those which had such a successful termination in the case of the Norfolk in January, 1864. The conditions of weather, however, are very different; then the cold was so great that it was difficult to prevent the ova from freezing in the boxes; now it has been so warm as to raise a question whether they will not have begun to undergo the organic changes towards development which generally take place about three days after fertilisation. If any considerable portion of the 
ova have passed this point, the check they will receive in the ice will seriously imperil them. But no care and forethought have been omitted; the ship is a fine one of $\mathbf{1 1 0 0}$ tons register, and looks as if she would beat a steamer, with wind enough to drive her. About the 20th instant these unconscious ova will start on their long journey, to wake, we hope, into conscious life in the southern hemisphere, and people all the shores of the Southern Ocean with salmon.

"We have referred in occasional notes to the success of the importation of salmontrout and brown trout into Tasmanian rivers, and, though no Salmo salar of indisputable identity has yet been sent home thence, the evidence from eye-witnesses that the Derwent is full of large salmon is very strong. Other members of the Salmonidæ, whose struggling bodies have been brought to basket by the angler in the river Plenty, have evidently had fine times of it. A trout weighing $9 \frac{1}{4}$ lbs. has been taken, which could not be more than four years old. The conditions of life, then, are 
eminently favourable to this member of the family, and it may fairly be presumed that they are equally so to the others, although the journey to the sea is a risk to which the salmon has probably been exposed.

"From a private letter we learn that a gentleman, fishing one day a week for eight weeks in the river Plenty (Tasmania), brought to basket thirty trout, averaging $1 \frac{1}{2} \mathrm{lbs}$. (among them one of $7 \mathrm{lbs}$.), all of them being bright fish, in fine condition. If the Tasmanian waters will yield such trout fishing within a few years, the angler of the future will surely have cause to rejoice.

"We cannot know at present whether this shipment of salmon ova to New Zealand will within a few years produce fresh-run fish; but with a favourable climate we have at least the first elements of success, and, whatever be the result, the thanks of all interested in angling, as well as in the scientific aspect of the experiment, are due to those gentlemen who have taken so much pains to bring it to a successful issue."

The result of this shipment was that 
ninety strong fish were eventually turned into the Jacobs, where, in May, 1875, many of them, which had then attained a length. of seven inches, were seen by Mr. Howard, who had reared them from the ova.

The method of packing this delicate freight for the colonies, it should be borne in mind, is the only plan which has hitherto yielded results, and its importance will, therefore, be justly estimated by the naturalist and pisciculturist. It may have occurred to the reader to ask why the shipments were always made so late in the season, when most of the salmon had spawned, and the difficulty of procuring gravid fish became greater every day. Acclimatisation is always surrounded by difficulties, and in this case by one of peculiar character. The ova must arrive during the colonial winter, in order that the temperature in the streams should be low enough to admit of their being safely transferred to the water. During any tirne in March the water would still be too warm, and in the first half of that month its temperature would probably be 
above $60^{\circ}$. To take salmon ova from the ice-house at a temperature of about $35^{\circ}$ and transfer them suddenly to one of $60^{\circ}$ would have the same effect as plunging them into boiling water! It was necessary that the vessel should start about the middle of January, and that she should be not more than ninety-five days on the passage, which would bring the ova into colonial waters in the latter half of April. And it is observable that the arrivals after the middle of April have produced the largest number of fish.

MR. FRANK BUCKLAND'S SHIPMENT.

Mr. Frank Buckland was next commissioned by the Otago Government to undertake a trial for New Zealand, the details of which will be found in Land and Water for January, 1875 ; but, unfortunately, it was a complete failure, partly owing, probably, to some causes over which he had no control, among them the extreme severity of the weather during the collection and packing 
of the eggs. The ova were taken by himself, Mr. Edon, Mr. Marshall, and others under his superintendence, and it is impossible to doubt that they were properly fertilized by one who has had so much experience in this work. The account of the packing had better be given in his own words. The ship Timarù was lying at Glasgow, and the ice-house built in her hold was capable of containing between thirty and forty tons of ice, and was surrounded by a "skin" of sawdust eighteen inches thick. The packing boxes measured a cubic foot, and inside each were five or six trays filled with sphagnum moss. "The tray containing moss was sunk into the water, the eggs were then taken from another vessel by means of a small shovel made of perforated zinc; with this they were then distributed among the moss, and, being still under water, were separated one from the other by means of a soft brush." This is all Mr. Buckland gives us! It secms to have been a complicated process, and the use of the shovel could not be 
otherwise than hurmful; but we confess we can gather from it no clear idea of the process. He appears to have employed no charcoal, and the distribution of the ova "among the moss" implies an amount of contact with various substances which would be prejudicial, according to all experience, to the delicate envelope of the ovum. "The ice-house was thus packed: first, ice two feet thick was arranged along the bottom. Then upon it were carefully deposited a square, consisting of twenty-five salmon egg boxes, each one foot cubic, and four boxes at each corner of the square. Upon these boxes came another stratum of ice, also two feet thick; on this stratum again another twenty-nine egg boxes. Ice again on the top of these. All round the sides of the ice-house was [were? ?] packed slabs of ice $2 \mathrm{ft} .6 \mathrm{in}$. thick, so that the boses containing the ova were surrounded on all sides by blocks of ice, the minimum thickness being two feet. Ice was also packed in the interspaces between each box, precautions being taken that they 
should not get loose." The arrangement, in fact, was that of alternate layers of boxes and ice-an excellent disposition, no doubt, if ice did not melt, but the best calculated, in these circumstances, to subject the boxes to the greatest possible amount of motion and concussion as the ice around and between them decreased in bulk. The last words of the description have no meaning, for it is obvious that no precautions avail to prevent the once compact mass from getting loose, and ice and boxes would at length become inextricably mixe $\bar{d}$ and dashed about with every pitch and roll of the ship.

This was one matter at least over which Mr. Buckland had control, and he would have been wise had he adopted the method of packing both ice and ova which had already proved successful. An impression was derived from a lecture delivered b5 him at Glasgow, and generally entertained, that the ova were frozen hard artificially before shipment, which would certainly have killed them, and though he has stated subse- 
quently that they were not, it was scaircely a judicious proceeding to pack them in an ice-house with "an ice-making machine freezing up an immense quantity of water into ice within a few inches of us while we were at work." The Timari sailed about January 5, 1875, from the Clyde, and had a passage of about a hundred and five days. Not a single salmon ovum reached land alive out of this splendid shipment of more than a quarter of a million, but a number of the charr eggs, presented by Mr. Parnaby of Keswick, hatched; of the ultimate fate of the fry from which no definite record has been obtained. We cannot attribute failure to the long passage alone, for Mr. Buckland hatched out eggs which had been in ice at the Wenham Lake Company's vault for only three days less than these; and a portion at least of the charr eggs, which naturally hatch earlier than those of salmon, and therefore, were subjected to a greater strain of retardation, produced fish.

Sincerely as Mr. Buckland's failure must be regretted, the "full responsibility" - as 
he says in his letter to the Times, in July, 1875 - rests with himself. Defeat must apparently be insured by the system of arrangement of alternate layers of boxes and ice, and the inevitable violence it must entail on the ova, when the ice melts and allows the boxes to knock about in the icehouse, sustaining a shock with every motion of the ship. The condition of the moss in the boxes on arrival is described as "sodden," and there is no difficulty in understanding. this impacted state of a fibrous vegetable material, kept continually wet by the water from the ice, supposing it to have been much shaken. When closely packed upon the floor of the ice-house (as had been done in all the successful instances) the boxes. cannot possibly move. The motion of the vessel carries them bodily with itself, and the ice does not move them. They are practically as firmly fixed as any of the ship's timbers, and the water from the ice, after passing through them, is done with, and drains into the bilge. By the system of alternate boxes and ice the water must 
pass through several sets of ova, losing its oxygen in contact with animal organisms, and contracting carbonic acid, and thus becoming more and more effete, and finally almost a deadly poison to the ova which receive it last. This decomposition of water by animal life, in any form, is so well-established a fact that it cannot be safely left out of consideration, and it is surprising that Mr. Buckland did not take it into account before deciding on an arrangement of the ice and boxes which involves serious mechanical and physiological dangers.

\section{THE "DURHAM."}

Instances have already been given of the danger of submitting salmon ova to concussion, even while they are in a vessel containing water, and the reader may have thought that this point has been exaggerated. On the contrary, too much stress cannot be laid upon it, as will be seen from the following. The boxes, it will be recol- 
lected, were screwed down as a precaution against the possibility of communicating a shock to the precious contents by the blows of the hammer in driving nails, and when one of the boxes of the shipment per screw steamer Durham, which is now to be described, was opened in Victoria, a nail was found to have been used instead of a screw in fastening the lid. If a mere coincidence, it was a strange one indeed; but the fact is the whole of the eggs in that box, with the exception of two or three, had long been dead!

Nothing having come of Mr. Buckland's shipment, the agent of the Otago Provincial Government requested Mr. Youl to undertake another in conjunction with that gentleman, the cost of which was, by arrangement, defrayed in equal proportions by the New Zealand Government and Sir Samuel Wilson, of Victoria, whose public spirit and careful preparations for the proper treatment of the ova in that colony merit warm recognition from the Victorians. Mr. Youl consented, on condition that he should 
supervise the construction of the ice-house, each packing his boxes in his own manner. On the 8th of January, 1876, Mr. Youl proked 40,000 ova taken by Mr. Ramsbottom from the Hodder, and placed them on the floor of the ice-house. The cold was intense, and many of the eggs were frozen and turned white, while the moss had to be thawed at the ship's galley fire hefore it could be used. On the 11th $\mathrm{Mr}$. Buckland brought 70,000 ova to the ship, already packed by his own method and taken from Lancashire rivers and fertilized by himself. These were also placed on the floor beside the others, and 15,000 more brought on the 13 th by him and placed in the middle of the ice, as the floor was already occupied. On the 14 th about 50,000 more svere brought from the Severn and packed by Mr. Youl and deposited at the very top of the ice-house (the boxes being clamped together and made immovable), which was smaller than any hitherto built, and contained about nineteen tons of ice. Thus there were 90,000 of Mr. Youl's packing 
and 85,000 manipulated by Mr. Buckland. The latter had discarded the tray system, and used boxes of the same kind and about twice as large as Mr. Youl's, but without charcoal and broken ice, and distributed the eggs upon the moss under water with a camel-hair brush in several alternate layers. The vessel having arrived at Melbourne, batches of boxes were distributed to the curator of the botanical gardeus, Geelong, Dr. Whitcombe of Ballarat, the Victoria Ice Company's works, and Sir Samuel Wiison, whose estate is near Lake Burrumbeet, who had made most careful preparation for the 30,000 ova of which he took charge. From a letter of Sir Samuel's it is evident that these yielded no result except five fish, which he hatched out, and only one survived. This is, no doubt rightly, attributed by Sir Samuel to the high temperature of the water at his hatching boxes, which stood at $60^{\circ}$ or $62^{\circ}$ for several consecutive days, though the situation is 1500 feet above the level of the sea. In Melbourne it was at first reported that 
Mr. Buckland's boxes were in better condition than Mr. Youl's; but the Melbourne Argus, which has been more trustworthy on the subject of these experiments throughout than any other colonial journal, says: "The result proved that Mr. Youl's system of packing was decidedly the best." However, the rest of the consignment being forwarded to New Zealand, Mr. Howard, the superintendent of the ponds at Wallace Town, Southland, can give the best account of the comparative results. Ou May 1, 1876, he writes to Mr. Youl: "Your own ova hatched as truly as if taken from one of our own rivers, scarcely a death at hatching. . . . The large boxes packed by you had scarcely a dead ovum in them. Mr. Buckland's lot, though some of them looked so well impregnated, have not hatched off well, so many died just before hatching, and so many of them burst."

On May 29th he says: "I arm sorry to say Mr. Buckland's have hatched very badly. .. . so many burst before hatching." At the Melbourne ice-house Mr. Clifford, who 
had nearly all of Mr. Buckland's boxes, says most of the eggs turned opaque, some few showed the eyes, "but all such have gone bad in a way quite new to me." Further, he observes, "I see the Canterbury people have hatched 300. . . These were all from your (Mr. Youl's) boxes." Mr. Howard succeeded in getting out some 10,000 young fish from the whole lot intrusted to him, of which sixty-eight were from Mr. Buckland's boxes. Altogether about 1500 of these were afterwards liberated.

It is a matter of public interest to ascertain the best method of treating ova for a long journey, and it seems the evidence is vastly in favour of Mr. Youl's. Mr. Buckland packed nearly twice as many in one box, the lower layers were submitted to the action of water already vitiated by contact with those above, and there was not only a greater mass of material in one place, but the decarbonizing and oxygenating pro* perties of the living moss are dissipated by the greater quantity of animal life to be 
sustained. These may be some of the causes of the failure of Mr. Buckland's plan, but, granting that they are not necessarily, while we are imperfectly acquainted with the true causes of success or failure, it would be prudent to adhere to a method of treatment which has justified itself hitherto in every instance. Mr. Buckland might possibly have hit upon an infallible plan, and the world would have been duly grateful to him for his discovery; but, as the event proved, the plan adopted was not calculated to insure success, and the whole valuable cargo of the Timaric was lost, when he might have commanded success, and still had room for independent experiments.

THE “CHIMBORAZO."

The following article appeared in the Field of January 26, 1878.

" It behoves the colonists to see that the consignment of salmon ova shipped this month by the Chimborazo (s.s.) is intrusted 
on arrival to competent hands. Sir Julius Vogel requested Mr. J. A. Youl to make arrangements for building an ice-house in this vessel, and packing a number of boxes of ova; but the time was short, and he concluded to make use of one of the icehouses already existing in the ship for the supply of the passengers. Mr. Ramsbottom, of Clitheroe, procured 24,000 salmon ova, which Mr. Youl packed in thirty-eight boxes at the vaults of the Wenham Lake Ice Company, and subsequently placed on the floor of the ice-house and covered with ten tons of ice. Thus it was hoped there would be enough ice for the passengers, and a sufficient remainder to maintain the ova. A few days afterwards, Mr. Buckland packed and placed in the same ice-house eighteen boxes, containing some 20,000 salmon ova, and one box of about 1,500 trout, presented by Mr. Capel. The ship left London on January 21st, and is expected to reach Melbourne in forty days from Plymouth vit the Cape, when the consignment would be transhipped by steamer to 
New Zealand. It is to be feared that Mr. Buckland has repeated the error of packing in boxes of too large a size, to which the failure of his shipment in the Timarì in 1875 may probably to no small extent be attributed. The moss on arrival was described as 'sodden,' as might be anticipated from the impacted condition a large body of wet vegetable matter would be likely to assume. It must be obvious besides, that, should death and decomposition take place in any box, the mortality would be greater in proportion to the numbers included in it. For the sake of the colony, however, we must hope that a good proportion of the consignment will arrive alive. The rivers of New Zealand present every possible favourable condition for the salmon. They rise in snow-clad mountains, and flow, now rapidly, now in deep broad pools, through rocky formations, and contain numerous boulders and overhanging banks for shelter; while along their upper courses are long stretches of fine gravel suitable for nesting. Along the banks for miles grows the native 
flax, which will afford shelter for the young fry. Food is abundant, and especially that kind which young fish require. Indeed, Mr. Dawbin is of opinion that the fry in the Wiwera Ponds could have maintained themselves, even in their circumscribed quarters, without artificial food. In these circumstances the colonists would seem to have the acclimatisation of salmon in their own hands, provided they place the ova on arrival in charge of a competent manager."

Mr. Howard found about 1500 to 2000 of Mr. Youl's good, and some 300 of Mr. Buckland's. (See Appendix.)

GENERAL RESULTS OF THF FOREGOING SHIPMENTS.

Since the memorable month of October, 1865, when the first of the family were committed to the waters of Tasmania to take their chance, many thousands of young salmon, salmon-trout, and brown trout have been set free in colonial streams, and it now remains to take stock of them and their 
progeny. We know that eleven years elapsed before a small river in Scotland was stocked with a newly introduced species, in spite of the facilities afforded by proximity to spawning grounds and a yearly supply of young fish, and it could not be anticipated that positive proof of the acclimatisation of the strangers at the Antipodes would be forthcoming in a year or two. Nevertheless, in October, 1869 and 1870, young salmonids, about nine inches long, were caught in the Derwent, and it is pretty clear that they must have been fish born in the river, and not the original smolts turned in in 1865, but their progeny. Experienced. salmon fishermen had seen fish of many pounds' weight 'leaping and swimming on the surface far above falls which only a powerful fish could surmount, and quite impracticable for the small native species, and declared them to be undoubted salmon. In 1871 Sir Robert Officer and others well acquainted with the salmon at home saw, when the river was in half flood, shoals of large fish leaping and showing their glitter- 
ing sides, one of which, of 4 lbs. weight, was imprudent enough to leap into a boat moored to a jetty. When examined, his dentition suggested salmon-trout; the flesh was a deep pink, and the flavour delicious. No one who saw them could doubt that these were fresh-run fish taking advantage of the "spate," and pushing their way joyfully to the fine spawning grounds of the Derwent and its six tributaries. That many of these were true salmon is conclusive from the fact that in the year when they were first observed no salmon-trout had been turned into the river; the latter were then mere fry in the breeding ponds. The almost inaccessible character of the river, obstructed by rocks and snags, and selected on this account, prevented the capture of any of these, but the testimony of nearly a hundred persons, residents on the banks, went to show that quantities of large fish, never till then seen in the river, were ascending between the end of March and the middle of August, a time when the winter freshes are coming down, and that which only a mi- 
gratory fish would choose. About the end of 1870 the colonists allowed an opportunity to slip-down the throat of his Excellency the Governor, alas! - of establishing once for all the presence of migratory salmonids in their rivers. Several were caught in a fixed net near the junction of the Plenty and Derwent, one of which weighed $7 \mathrm{lbs}$, and, like its brethren, was pronounced to be as fine in appearance and taste as any Tay salmon. No means appear to have been taken to ascertain its species, whether salmon or salmon-trout, and the intense expectation with which proofs were looked for by all interested in acclimatisation was disappointed by this means of disposing of the question. Obviously, the specimen should have been sent to England for the best scientific opinion. The soundness of Mr. Francis Francis' judgment is beyond dispute, and his opinion was given in unequivocal terms in a letter to the Field, Feb. 21, 1874: "I have never wavered in the belief that the fish seen leaping in the Derwent were actual salmon. Mr. Youl's 
name will be remembered in that vast Australian world when the New Zealander shall be again spearing salmon from a broken pier of London Bridge."

From time to time, up to the present, salmon or salmon-trout-the species not always being determinable-have been captured by the fishermen and others, and so keen has been the competition among hotel keepers, \&c., that they have been sold as high as 5s. per lb.! Poaching has no doubt gone on to a great extent over the wide area of water occupied by the Derwent and its bays, which it is impossible to effectually protect, and it is certain that many fine fish have been taken, unknown to the authorities. In 1873 numerous smolts were caught, which conclusively proves that these had been bred in the river. In one haul of a seine net in the estuary seventysix young fish, varying from $\frac{3}{4} \mathrm{lb}$. to $1 \frac{1}{2} \mathrm{lbs}$., were secured in January, 1876, and on subsequent days many more, making a total of about 200 ; and a little later a dense shoal of fish were seen near the shore pursued by 
porpoises, when an observer threw a billet of wood at them, and disabled one, which was secured, and found to be a finely developed Salmo salar of $4 \frac{1}{2}$ lbs. weight. From these facts the abundance of fish in the locality may be inferred, and the youth of some of them is conclusive as to their being native born, while the full development of others is indicative of suitable conditions of life. The breeding ponds on the Plenty have been the nursery and centre of distribution for the other colonies. They are admirably arranged on an artificial stream forming a loop with the river, and cover about three and a half acres. During the years 1873, 1874, 1875, and 1876, nearly two thousand salmon-trout ova and four hundred fry (the produce of the prisoners) have been distributed to streams in Tasmania, New Zealand, and Victoria, and 33,850 trout ova and fry to suitable streams in Tasmania, New Zealand, Victoria, New South Wales, and Western Australia, thus covering the whole colonial area-a work most creditable to the energy and public 
spirit of the commissioners. It appears that none of the acclimatised species show much disposition to take the artificial fly, owing, very probably, to the abundance of insect food continually being blown into the river, which would induce much the same contempt for the devices of man as trout evince in our own rivers when the maytly is on the water. It was, then, an interesting event when an unquestionable salmon was caught by one of the commissioners, fishing with an artificial fly from a boat below the falls at New Norfolk in October, 1876, one of a numerous shoal then going up the river; and again in January, 1877, when a beautiful fish of the same species, weighing $8 \frac{1}{2}$ lbs., fell to the rod of his Excellency the Governor of Tasmania.

The breeding places of the fish in the Derwent have not yet been discovered, but they are no doubt at the head of its affluents, where there is little or no population; and it is almost impossible to use a net, owing to the irregularity of the bottom 
and the mass of fallen timber obstructing the streams affording efficient protection to the fish, but interfering with the project of collecting ova for distribution. It is here, however, that a permanent source of supply must be looked for, and means should be taken to watch the upper waters and note where the fish are making their nests, a spectacle they are not in the least chary of exhibiting to human ken-at least, in our part of the world-so engrossed are they with the anxieties and excitements of the interesting event. The need for obtaining a supply from the river becomes more evident when we learn that latterly an increasing proportion of the ova from the imprisoned fish have proved infertile, and every effort is now being made to effect this.

Little is yet known of the ultimate results of the shipments to New Zealand, but about the middle of the year 1874 a salmon grilse, weighing more than three pounds, was taken in the river Molyneux (Otago), no doubt the offspring of a pair 
of the five hundred smolts liberated in that river in 1869 by $\mathrm{Mr}$. Dawbin.

Difficult as it is to distinguish between the migratory species of the salmon family at an early age, there are now many gentlemen in the colonies quite as competent to give a trustworthy opinion, from the distinguishing anatomical characters, as any but the most expert of our home naturalists, and their judgment may be accepted with some confidence.

Eighteen years have now elapsed since the first trout was born in Australian waters, and many facts point to an extraordinary rate of growth in these fish. In 1874 a splendid fellow of over $16 \mathrm{lbs}$. was taken by the rod in the Derwent, and the trout of $9 \frac{1}{4}$ lbs., which could not have been four years old at the utmost, has already been mentioned. The rods have had a good time of it in the rivers now open to the angler, and there are numbers besides where the fish are awaiting him. A beauty of $5 \frac{1}{2} \mathrm{lbs}$. fell to the fly in the Clyde, where the fry had been turned in little more than three 
years previously. Some of the "bags" would almost make a defunct fly fisherman turn in his grave. Mr. Weaver, in 1872, took, during one afternoon and one morning, six trout scaling $30 \mathrm{lbs}$, and one of the lot nearly $9 \mathrm{lbs}$., from the Derwent. Looking over the diary of a New Zealand fisherman for 1877, we find, on various days, nine fish, weight $20 \mathrm{lbs} .4$ oz.; six, weight $10 \mathrm{lbs}$. ; two,

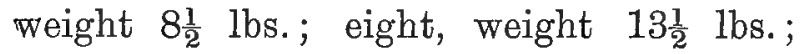
three, weight $14 \frac{1}{2}$ lbs., and so on, fish over a pound greatly predominating, and many smaller being returned to the water. The flies used were chiefly the black gnat and March brown, but the green grasshopper proved the most deadly of all to the larger fish. Trout have been established in about a score of streams in New Zealand alone, and, perhaps, as many more in Tasmania and Australia. What a prospect, then, for the angler of the future! What, for instance, may be, the size of the trout which, after many years of gluttony in the pools of Gippsland rivers, remote now from human habitations, shall rise confidingly to 
the fly or quietly suck in the worm of the first adventurous sportsman who casts his line over those waters? Long after our home fish have attained so critical an experience as to know at a glance the maker of the fly offered them-they really seem to be coming to this-the unsophisticated denizens of Australia will rush at the grasshopper impaled on the bent pin of the rustic urchin, and as certainly become a regular item of the shepherd's evening meal as the Murray cod has been of mine in many a lonely hut on the Maranoa. Often, when fishing for these so-called cod with a thick cord and large hook, baited with a lump of raw beef, cast into the stream to await first the gentle shake, then the tug and rush of a fish whose pluck is soon out of him, has the writer wondered that nature had not implanted here the lordly salmon, and speculated whether he would ever populate this magnificent system of rivers, as no doubt now some day he may, at least, in the person of the Californian species. Memory lingers fondly over those broad plains, vast forests, 
deep silent lakes, and swift streams set in the glorious sunlight of an Australian afternoon, when the rapidly lengthening shadows warn the hungry shepherd and bleating flock homewards, and

Pulsæ referunt ad sidera valles;

Cogere donec oves stabulis, numerumque referre Jussit, et invito processit Vesper Olympo.

The species of trout which has spread or is rapidly spreading over the island waters of the Antipodes is that known to naturalists as Salmo fario Ausonii, the southern form, a finer species altogether than the northern (Fario Gaimardi).

Individuals have shown marked differences of colour, especially of the stomach, but in form and size the fish have bred true to their origin, and have apparently outstripped their English ancestors in rapidity of growth, while retaining their excellence of flavour and beauty.

In 1876 an attempt was made to acclimatise the Pacific coast salmon (Salmo quinnat) in Australia. Accordingly, a consignment of fifty thousand ova was made by $\mathrm{Mr}$. 
Spencer F. Baird, of the U.S. Fisheries Commission, from the upper waters of the Sacramento, California, half of which was left at Sydney, where "most of the living eggs were successfully treated and placed in Australian waters," as Mr. Baird says, and the remainder died on their way to New Zealand. This gives us no idea of the final success or otherwise of the experiment, for it is not stated whether any young fish were produced.

The subsequent endeavours of Sir Samuel Wilson to establish this fish in Victorian waters deserves all the success due to his energy and persistence; but as yet nothing has been seen of the young fry liberated in various streams.

It is, however, at least open to much question whether the greatest river system in Australia-the Murray and its tributaries -will ever be stocked with any species of salmo, since it swarms with the rapacious so-called Murray cod-a devourer of everything that gets into the water, from a grasshopper to a dead bullock. 
The writer has caught in the Condamine, with a lump of raw beef and a thick hand line, thirty pound's weight of these fish in an afternoon, averaging three pounds each; and individuals of twenty pounds' weight are not scarce. There is also the "cat-fish," a most voracious bottom feeder. Between these two species neither the ova nor young fry of salmon would appear to have much chance of survival. For the greater part of their course these rivers flow through alluvial plains where the muddy bottom would afford no suitable resting-places.

The Australian colonists may well desire the acclimatisation in their rivers of the Pacific coast salmon. Its commercial value is immense. During the year 1874 the works on the Columbia river, in Washington territory, tinned for export 22,000,000 lbs. of Salmo quinnat, and the manager estimates that $11,000,000 \mathrm{lbs}$. of fresh and salt fish in addition were taken for local consumption.

There is a belief, based on the observations of Mr. James Hector chiefly, and 
supported by the Indians and trappers, that the Pacific salmon dies after spawning (see the U.S. Fisheries Commission Report 1872-73, p. 191). Should this be a fact, the stocking of a river with this species would probably be a slow process. Nevertheless, the history of success at the Antipodes and in America with the British species affords ample encouragement to the most sanguine pisciculturist. From "The Twelfth Annual Report to the Commonwealth of Massachusetts," we learn that from 1872 to 1876 more than 830,000 parr of $S$. salar were turned into the Merrimac, and in the spring of 1877 hundreds of fine fish were seen ascending the river, of which some were estimated to be eighteen or twenty pounds in weight. The Report observes very significantly, "It will be seen that what we have so long fought for, what the mass of people here have generally considered mere theories, visions of men who suffered from fish on the brain, has been fully substantiated. It is true it took a little longer than was at first thought; but now 
Massachusetts knows that, while she was the first of the States to take an interest in fish-culture, so she has been the first to demonstrate the certainty of a good return, and she can restock those rivers where the fish have already been killed out."

Notwithstanding the large numbers of S. quinnat which have been liberated in New England streams, no one can say with certainty that a single smolt has ever been seen. This is not so favourable an augury for Australia as could be wished.

The latest shipment was made by the John Elder in January, 1882, under the able superintendence of Mr. Charles C. Capel (the owners liberally taking the consignment free), and at the request of the Acclimatisation Society of Otago, Mr. Capel collected, through his manager Mr. Cross, and with the assistance of Mr. J. M. Ridley, chairman of the Tyne Fishery Board, and Mr. Harbottle the inspector, 130,000 salmon ova, which were packed entirely to $\mathrm{Mr}$. Capel's satisfaction. They were to be transhipped at Melbourne for Dunedin. From 
a letter from Mr. Capel, dated May the 6th, 1882, it unfortunately appears that he had received a discouraging report of the consignment from Melbourne; but it is of course too early yet to draw any conclusions.

The almost universal opinion expressed at the beginning of these endeavours to acclimatise salmon in Australasia pointed to certain failure, if the ova were sent in moss. The French pisciculturists were confident that they could not be carried thus a long sea voyage. Yet there was no intelligible ground for the prediction, and the very first trial demonstrated the practicability of the plan. A writer in one of the leading colonial journals took upon himself to recommend that the ova should show the eye before they were placed in the ice-house, forgetting the fact that they would hatch out within three weeks if so far developed, and what would the young fish do in the moss without a stream of water? This, however, was not the most curious example of advice tendered by some who had yet to learn the elements of natural history. 
There are many risks to the delicate ova in transmitting them to Tasmania, beside those of procuring and packing them. Thus, for instance; on arrival at Melbourne, they were landed, transferred to another ship, underwent a second sea voyage of some five hundred miles to Hobart Town, then taken in a barge twenty miles up the Derwent, and finally carried five miles across rough country to the breeding ponds on the Plenty. We may, indeed, feel surprise that any should have reached their destination safely.

Various persons have from time to time claimed to be the originators of Mr. Youl's plan of transport, or it has been claimed for them by others, and sometimes the recipients of this undeserved honour have accepted it as their due, although they knew they had no title to it. The writer has made it his business to institute a searching inquiry into these claims (and a somewhat laborious task it has been), because it seemed to him that, if he assumed the rôle of historian of an important experiment in acclimatisation, nothing less was due to the reader than the 
most complete investigation of all the evidence bearing upon it. The late Dr. E. Gray advanced a claim on behalf of the late Dr. John Davy, as the author of the moss and ice transport plan. Much of the controversy was carried on in the Athenceum, in February and March, 1866. It seems that Dr. Gray was misled by a report in a colonial newspaper, the writer of which made many erroneous statements of facts, in ignorance that those facts had already been published in an accurate form. Mr. Youl could not have borrowed his idea from Dr. Davy, for they never met nor ever had any communication whatever. Subsequently this claim was abandoned by Dr. Gray in a letter to Mr. Youl, which he wrote in the presence of the latter, giving full permission for its publication. This letter was sent to Mr. E. A. Watts, then editor of the Melbourne Argus, and its substance was embodied in letters by Mr. Watts to the Athenceum of the above date. After this complete disavowal of Dr. Davy's claim, it is greatly to be regretted that Dr. Gray 
reasserted it in a letter to Dr. Buller which was published in the official "Papers relating to the Introduction of Salmon Ova into New Zealand, 1872 " (G. No. 26). The disingenuous character of the letter must be apparent to every one who reads it. Mr. Frank Buckland has done so much good service in fish culture and preservation that he needs no other title to public recognition. However, there is an impression that he was the author of the acclimatisation of salmon at the Antipodes-an impression which must be dispersed. It is comparatively easy to correct a mis-statement when made viva voce, but if it appears in a newspaper the correction should also be admitted in its columns. This was not the case with the Pall Mall Gazette, to which the writer sent two distinct communications, pointing out the error in the following sentence in the issue of August 7, 1873, in a paragraph referring to the shipment of salmon ova per Oberon in that year: "The experiments which have hitherto been carried on by $\mathrm{Mr}$. Buckland and others," \&c. No notice what- 
ever was taken of the correction offered, but the writer applied with better success to the editor of "that mighty pastoral," the Field, who published these comments upon the subject on September 6th following.

"Sir,-If history is to be written from newspapers, I presume that a mis-statement should not be allowed to pass uncorrected. I believed it to be the custom when an error in fact had been made by a public journal that a correction of it was accepted and published, provided the name and address of the person offering the correction were given, and there was no reasonable ground to doubt the accuracy of his knowledge. I represented to your contemporary, the Pall Mall Gazette, that a mistake had been made in that journal on the 7 th of August in a short paragraph on the recent shipment of salmon ova to Otago, which gave to one person the chief credit of important operations in fish culture. The sentence ran thus: "The experiments which have hitherto been carried on under the superintendence of Mr. Buckland and 
others, have unfortunately as yet resulted in no positive proof of success.' The experiments referred to are the shipments of salmon ova to the Australasian colonies. In case Mr. Buckland should not have seen the paragraph in the Pall Mall Gazette, I wish to give him an opportunity of unbinding this wreath of triumph from his brows. In the meantime, I wish to inform your readers, and the readers of the Pall Mall Gazette besides, that Mr. Buckland has not had the chief or even part superintendence of any one of the experiments which have resulted in a great achievement in fish culture, even if we go no further than the production of living salmon in Tasmania and New Zealand. Mr. James A. Youl was the originator of the successful plan, after many others had failed, and has arranged and superintended all the shipments personally and solely.

"I have good authority for this statement, because I believe that every document on the subject, from first to last, official and private, has passed through my hands; and 
possibly no one, except Mr. Youl, is better acquainted with the history and method of the experiments from February, 1860, to the last by the Oberon in January, 1873.

"Should any of your readers desire particulars of the method adopted in sending salmon ova to the Antipodes, I may refer them to a description of the process which you were good enough to publish for me in the Field of the 18th of January last.

"I am the more anxious to seek your assistance in correcting the least erroneous impression upon the subject of these shipments, because, on account of the reluctance of Mr. Youl to combat them, they have become widely spread.

$* \quad * \quad * \quad * \quad *$

"I find in a leading article of Land and Water for January 18, 1873, the following: remarks, which could not have been published without Mr. Buckland's sanction, and were, I suspect, from his pen.

"To J. A. Youl, Esq., is due the practical management of this great and important 
experiment. With an earnest vigour and an intense energy he has managed all the details, from the official correspondence to the soldering down of the ice-house; and to this gentleman Australia and New Zealand will owe the introduction of salmon. Should this valuable fish be eventually acclimatised, these colonies will hereafter look upon Mr. Youl as one of the greatest benefactors of his age.'

"No more handsome acknowledgment could be given than this; and Mr. Buckland (assuming that he wrote the article) does not even take the credit due to himself for his own contributions in the shape of trout and salmon ova, sent or brought by himself to the docks on more than one occasion while the packing was going on.

"I am induced to trouble you with this letter because my two applications to the Pall Mall Gazette to correct its error have been ignored, and in simple justice to $\mathrm{Mr}$. J.A. Youl, who, at the request of the several Governments of Australia and New Zealand, 
undertook gratuitously the superintendence of all the shipments of ova to the Antipodes. "Arthur Nicols."

"Sept. 1st, 1873.

The above letter was never challenged. The reader already knows that Mr. Buckland had made no experiment in this direction, either alone or in conjunction with others, until his unfortunate failure in the Timarù two years later.

After this it is instructive to read a letter from Mr. Buckland published in the Reports for 1873 , in which he undertakes to teach the authorities of New Zealand the proper method of treating ova for shipment, very much as though he were the only person who knew anything about it, and had originated it.*

In a letter to the Field of June, 1878, Sir S. Wilson says, addressing Mr. Youl-

"Only for your happy thought of trying the experiment of packing the ova in ice, our continent would still have been without

* See Appendix. 
the prospect of obtaining this valuable fish, and your perseverance in this patriotic effort, which has resulted so successfully, is deserving of every praise, and has not yet been acknowledged in the manner which it deserves to be.

"On behalf of Australia, if I may be permitted to speak in her name, I beg to offer iny warmest and most grateful thanks for the exertions which you have so cheerfully bestowed, as well as for former valuable services of the same kind."

Mr. Thomas Brady, one of the Salmon Commissioners for Ireland, also bears the same testimony in a letter to Land and Water of February 9, 1878.

The whole of the success has been claimed for Mr. Buckland repeatedly, and he has not been careful to disavow the honour at all times and in all places, while a gentleman who has done good service, Mr. R. Dawbin of New Zealand, has been ignored in official reports and everywhere else. He and Mrs. Dawbin nursed the young fry from the ova isent out by the Celestial Queen with such 
assiduity and excellent judgment that they were finally enabled to despatch five hundred fine smolts to the sea. Had Mr. Buckland done as much as this even it. would have entitled him to consider he had some share in the establishment of salmon in that colony. Some recognition of $\mathrm{Mr}$. Youl's efforts to benefit the colonies commercially and to solve a knotty scientific problem has been made by the colonial governments and acclimatisation societies, in the form of votes of thanks and medals, and Lord Carnarvon recommended him to her Majesty for the distinction of Companionship of the order of St. Michael and St. George, which has accordingly been conferred upon him expressly in acknowledgment of this service to the colonies.

That salmon-trout and brown trout are now abundant in colonial streams is incontestable, and scarcely less certain that salmon are also plentiful; it remains for the colonists to foster their rich property. There is no reason why every stream and lake south of the 28th parallel of latitude. 
should not become a home for some of the Salmonide, and the tarns and lakes of New Zealand should be full of trout. But let the colonists see that no young salmon or salmon-trout are turned into rivers where trout are already established, as there is reason to fear has been done in some instances, for few, if any, will escape the voracious jaws of their brown cousins and reach the sea. It is doubtful even whether the attempt to introduce the Pacific coast salmon into New Zealand was wise until the establishment of the better species was assured, and it would be the worst economy to withhold sufficient funds for adequate protection of the imported fish, as has hitherto been the disposition of the colonial legislatures.

Sir R. Officer, dating his letter December 27, 1877, thus writes to Mr. Youl-

"The chief object of my now writing is to communicate a fact which I think you will-as I have done-regard as the crowning event in the lengthened history of our undertaking. The salmon have during the 
past season, if not before, begun to make their nests and deposit their spawn in the Plenty, and we have now some of their produce in our ponds! One of the fish that had thus returned to propagate its species in its native water I saw myself before leaving Tasmania in August last. It then weighed 20 lbs., but as it had parted with nearly all its ova, it may be set down as a fish of at least $25 \mathrm{lbs}$. It was quickly replaced on its spawning bed in the Plenty, in close proximity to the ponds, from which it had been gently removed in a landing net and where it finished its operations. One attendant male fish, that I did not see, was afterwards weighed, and found to be about 18 lbs.

* $\quad * \quad * \quad * \quad *$

"With the salmon breeding in the Plenty, so admirably fitted for the purpose, abundance of ova and young fish may hereafter be obtained for stocking speedily all the rivers in Tasmania. I hope to have something further of interest to communicate to 
you ere long, and, among other things, that we have been able to secure a fish of sufficient size and condition for transmission to yourself, to whom we are so much indebted : a duty which I shall not lose sight of.

"Believe me, ever yours faithfully, "R. OFFICER."

"P.S.-You will have seen in the Argus reports of Sir S. Wilson's strenuous efforts to introduce the Californian salmon into Victoria. He deserves success; but there are, unfortunately, no Derwents, Huons, Gordons, or Esks to which he can look as a future home for his nurslings. We have always heard that the Californian fish is inferior to the denizens of the Tay and Tweed, and have therefore had no desire to get any supplies from that quarter, but to rely on what has passed through your hands only, and so preserve the species pure and unmixed.

R. O."

The above was published in the Field, February 16, 1878. 
Every rustic now knows that these fish are to be found in the rivers, and the deadly worm has been employed with too good success in districts remote from the influence of the commissioners. It would be well if stringent protective powers were conferred upon riparian proprietors, but nothing will avail to prevent the destructive use of net and rod in streams which run through unappropriated land, which spawning fish will be sure to frequent. The only hope for these is the great prolificacy of the fish and the sparse population. The river Plenty has been opened to rod-fishing since 1870 , at a license of $£ 1$ per rod, and the commissioners anticipate a considerable and permanent revenue from this source-it yielded $£ 100$ in 1876-while this measure tends to keep down the large fish of $5 \mathrm{lbs}$. and upwards, which are frequently seen lurking under the banks, and living in luxmrious ease on the small fry of their own species.

Indeed, the rapid growth of trout in the Derwent and its tributaries is a serious danger to the spawn and fry of the migratory 
species, and it would be wise to exterminate the former as far as possible in localities selected by the latter as their nurseries. This danger should be guarded against elsewhere by the reservation of some rivers solely for salmon and salmon-trout, though the temptation to introduce the easily established trout may be very strong, and has, it is to be feared, already proved stronger than prudence. The decreasing fertility of the prisoners referred to in the latest report of the commissioners suggests the probable necessity of further importations of ova from England, and should this be decided upon, the colonial authorities should insist on the adoption of that plan of transport which has proved successful in Mr. Youl's hands, and allow no modification of it. The course to be pursued by Victoria is now clear. On the arrival of the ova in that colony the temperature of the water may be expected to range as high as $60^{\circ}$ Fahr.; therefore, sufficient ice must be provided to keep the temperature of the water in the hatching boxes at least down to $45^{\circ}$, 
and much lower for the first few days, until the young fish appear. With this precaution success will be deserved, if not achieved.

It has been attempted to trace the successive steps in the history of a bold experiment in acclimatisation, followed by a wellwon triumph ; it only remains to congratulate the colonies on the valuable acquisition, and it should not be necessary to bid them remember that they owe it to the patriotic exertions of onè who has held a high position as a citizen in Tasmania, among whose greatest benefactors he should now be counted; while he himself might justly exclaim,

"Exegi momentum ære perennius Regalique situ pyramidum altius." 


\section{APPENDIX.}





\section{TASMANIA, 1862.}

\section{SALMON.}

RETURN TO AN ORDER OF THE HOUSE.

\section{R E P O R T.}

To Itis Excellency Colonel Gore Browne, C.B., Captain-General and Governor-in-Chief of the Island of Trismania.

May it please Your Exceluency,

The Commissioners appointed by Your Excellency to direct the measures to be adopted for the introduction of Salmon into the Rivers of this Colony have already reported to the Government the arrival of the Beautiful Star, and the disastrous result of their first experiment.

They have now the honor to lay before Your Excellency a Report of their proceedings, in their efforts to fulfil the important duty confided to them, from the date of their appointments to the present time.

During the Parliamentary Session of 1860, the question of the introduction of Salmon was re. ferred to a Joint Committee of both Houses. In 
their Report, presented to both Houses, the Committee recommended that all the arrangements. necessary to be made in England in furtherance of this highly important undertaking should be entrusted to the Committee of the Australian Association in London; and, before the appointment of the Commission had been issued by Your Excellency, that body, acting under the authority and instructions received from the Executive Government of the Colony, had already made progress in the task they had undertaken, and had completed all their arrangements before any communication reached, or could have reached, them from the Commissioners.

Aware that among the Members of the Australian Association there were many gentlemen of great intelligence, intimately connected with this and the neighbouring Colonies, to all of which the enterprise was of deep interest, who would willingly give their best services to promote its success, the Commissioners cannot but regard as judicious this recommendation of the Committee.

Among others to whom the Committee had looked for valuable assistance was $\mathrm{Mr}$. Edward Wilson, of Melbourne, who had already distinguished himself so greatly by his zeal in the rork of acclimatisation. The services of this gentleman were, however, lost to the enterprise, by his early 
return to Victoria, and its chief direction fell into the hands of our fellow-colonist, James A. Youl, Esq.

The zeal and energy displayed by Mr. Youl in the performance of this voluntary and patriotic duty deserve the highest commendation. No personal labour was spared by him to ensure the successful result of the experiment. Mr. Youl was, from the fixst, fully impressed with the importance of embarking the Ova in a vessel at once swift and roomy, and sailing direct to the Port of Hobart Town. He appears, however, to have encountered much difficulty in his efforts to secure these three conditions-essential, in the opinion of the Commissioners, to the success of the undertaking.

This difficulty arose chiefly from the fact that, at the season during which the Ova could be obtained, none of the regular first-class ships sailed for this Colony, and that none of the clipper vessels trading to Melbourne could be induced to incur the delay and risk involved in calling at this Port.

After the failure of other negociations however, the owners of a large and fast ship, the Zealander, fulfilling all the necessary conditions, offered to convey the Ova to Hobart Town for a sum of $£ 750$. At the same time an offer to perform this service 
was made by the owners of a small iron steamer, of only 120 tons, for a charge of $£ 500$, but which was to make the voyage jury rigged, and with sails only. The Commissioners think Mr. Ioul committed a fatal error of judgment in preferring this vessel to the Zeclander; and since they heard that the Ora had been placed on board the Bcautiful Star, they have regarded the success of the enterprise as all but desperate.*

The charge of the experiment on board of the Beautiful Star was entrusted to Mr. W. Ramsbottom, a son of Mr. R. Ramsbottom, long distinguished for his skill in the artificial propagation of Salmon.

Mr. W. Ramsbottom has placed in the hands of the Commissioners the Journal kept by him during the voyage of the Beautiful Star, and has also furnished them with a Report on the whole experiment. From these sources, from personal communication with $\mathrm{Mr}_{\mathrm{r}}$. Ramsbottom, and an inspection of the vessel and the apparatus in which the Ova were placed, the Commissioners have obtained a clear perception of all the causes which have led to the failure of this undertaking, and of the conditions that are necessary to a successful result on a future occasion.

* No error of judgment. The Zealander could not after all be sectured.-A. $\mathrm{X}$. 
The character of the vessel in which the experiment was made must, without other defects, have rendered success all but impossible.

Under no conditions could it be supposed that the Ova or Fry would survive 160 days at sea, nor could it be expected that a vessel of the dimensions of the Becutiful Star, and rigged as she was, could perform the voyage much under that period.

The suspended apparatus appears to have been skilfully contrived; and in a suitable vessel, and under other proper conditions, would in all probability have brought their charge in safety to their destination.

But the small dimensions of the ressel did not afford space to permit it to swing freely, and the constant and excessive rolling kept the gravel in which the Ova were deposited continually shifting, causing their death by mere attrition; and, from the same cause, the apparatus could not safely be approached for many days in succession.

Mr. Ramsbottom has, however, pointed out some changes in the construction of the suspensory apparatus which would, in the opinion of the Commissioners, considerably improve it, and render it as near as possible perfect for a future experiment.

The second apparatus, constructed on the gimbal principle, was a failure from the first; and, by its 
excessive motion, soon caused the death of all the Ova which had been placed in it.

But if the Ova had not nearly all perished from the cause referred to, the failure of the ice, 74 days after the sailing of the vessel, must necessarily have led to the same disastrous result; although on board a fast vessel its duration for that period might have been sufficient.

Mr. Ramsbottom calculates that at least twothirds of the ice embarked, amounting to 25 tons, were lost by melting.

The Commissioners are, however, of opinion that a great part of this excessive waste was due to the faulty construction of the Ice-house, and the mode in which the stream of water was made to pass through it from the tanks to the trays. They believe that such improvements could be made as would certainly guard against this source of failure, and secure the preservation of the ice for a period much beyond that occupied in an ordinary voyage from England to this Colony."

At an early period of the voyage, Mr. Ramsbottom discovered another source of disaster, which, if he had not been able to remove it, by the detention of the vessel at Scilly, would alone hare caused the destruction of the Ova.

It was found that the water contained in the $\because$ The ice-house was in fact most carefully constructed. 
iron tanks brought with it to the trays, and deposited on the Ova, so considerable a quantity of that metal, in the form of a fine powder, as to cause the death of great numbers of them before a remedy could be supplied. The remedy consisted in causing the water to pass throngh a filter before it reached the trays.

The use of wooden tanks, lined with block tin or slate, would effectually prevent future disaster from a similar cause.

The Commissioners have learned that some of the Ova were several weeks old when first placed on the trays. They notice this fact more with reference to any future experiment that may be undertaken than to that which has just terminated. They are of opinion that every precaution ought to be taken to retard the hatching of the Fry during: the voyage, and that, as one important means of obtaining this end, the Ova when embarked should not be more than a few days old.

Mr. Ramsbottom appears to the Commissioners to be thoroughly acquainted with the duty he undertook to perform, and to have discharged it with much diligence and zeal.

They believe that if another effort of the same nature should be made, it could not be confided to a more efficient agent, or one more likely to ensure a successful result. 
The chief practical work that the Commissioners have had to perform has consisted in the necessary preparations for the reception of the Salmon Ova, if they should happily reach the Colony in safety, and the construction of a breeding pond.

At their first Meeting, the Commissioners unanimously decided that their attention should at first be confined to the stocking of the Derwent; and that the breeding ponds should be constructed on the bank of one of its tributaries.

After a careful personal inspection of the locality, a spot on the east bank of the River Plenty, about two miles from its junction with the Derwent, was selected as the site of the Pond.

The Commissioners were led to this selection by the generally ample volume, low temperature, and gravelly bed of this stream; while its proximity to the head of the navigable portion of the Derrent, above New Norfolk, affords facilities for the safe transport of the Ora from the vessel importing them to the ponds.

Several other important advantages were secured by this selection; among which were the much smaller cost at which the pond could be constructed on the bank of the Plenty than on the main stream, the more complete security from the danger of floods, and the easier capture of the fish on their return from the sea, for the purpose of further propagation. 
The land on the east bank of the Plenty is the property of Robert Read, Esq., of Redlands, and the thanks of the Commissioners are due to that gentleman for the liberal spirit displayed by hirm in offering, without restriction, the use of any portion of his ground that the Commissioners might deem most suitable for the object they had in view.

After due exploration, a piece of ground, about three acres in extent, half a mile above Mr. Read's residence, was chosen as the site of the ponds. The ground thus selected offered every necessary facility for the cheap and expeditious accomplishment of the undertaking, and was at the same time sufficiently elevated to protect it from the reach of the highest known floods. By Mr. Read's further liberality, permission was obtained to procure the necessary supply of water from his main irrigation channel, by which the labour and heary expense of a long cutting to the river itself was saved to the public. It was $\mathrm{Mr}$. Read's desire that the use of his land should be gratuitous; but the Commissioners deemed it desirable that a small rent should be paid under a regular and formal lease.

A lease for fourteen years, at a yearly rental of $£ 15$, was accordingly prepared, and, on its due execution, the Commissioners lost no time in commencing the necessary operations. 
The pond has long since been completed; and the Commissioners believe that in no part of the world has a more perfect work of this character ever been constructed.

Although deeply disappointed by the failure of the late attempt to introduce the Salmon into the Colony, the Commissioners entertain a confident hope that, at no distant period, the work thus constructed under their direction will be put to the test of actual experiment; and they desire to express their earnest trust that the Government and Legislature will not abandon an enterprise, which is calculated to confer on this Colony a material benefit at once so extensive and so enduring, until success has crowned their efforts.

They believe that the stocking of our rivers with Salmon would confer a prominence and distinction on Tasmania which cannot be anticipated from almost any other source.

Until the subject has been further brought under the consideration of the Government and the Parliament, the Commissioners refrain from offering any specific proposal for the further prosecution of the undertaking.

They may, however, with propriety now observe that two other plans for the introduction of Salmon have often been proposed as a substitute for the direct action of the Government. 
It has been suggested that this important object might be attained by the offer of an adequate reward, or by calling for Tenders.

Both of these plans possess the advantage of securing the Colony against pecuniary loss in the event of the failure of the attempt; and they might both, with propriety, be had recourse to, at least, without risls.

But the Commissioners greatly doubt whether an enterprise, which must be new to whatever parties might undertake it, and which would involve in it the embarkation of so considerable a capital, is likely to be soon accomplished in that manner. On the other hand, the Commissioners are of opinion that the causes of probable failure in a future undertaking have been so well ascertained from the late experiment, and could be so certainly obviated and guarded against, that success could hardly fail to crown another effort, except in the case of actual shipwreck, or some similar disaster.

As the Colonies of New South Wales, Victoria, South Australia, and New Zealand are all more or less interested in this question, they may all be expected to bear a share in the expense of future undertakings.

Victoria has already liberally assisted us, and a contribution of $£ 200$ has been received from New Zealand. The cost of another, and of each suc- 
ceeding experiment, if more than one should be found necessary, would certainly not exceed $£ 1000$, which, divided among the five Colonies, would only

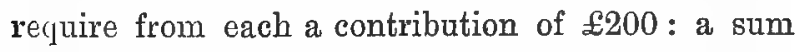
quite insignificant when compared with the importance of the enterprise, and the benefits that must flow from its successful accomplishment.

But whatever future measures may be adopted for the further prosecution of this great undertaling, the Commissioners trust that the unalterable motto of this Colony, at least, will be "Try again," until the difficulties have been orercome, and complete success achieved.

The Commissioners respectfully refer Iour Excellency to the Report of Mr. Ramsbottom, transmitted herewith, for details connected with the experiment on board the Beautiful Star, which it is not deemed necessary to embody in their Report.

A statement of the whole expenditure incurred in this experiment is hereto appended. The expenditure under the direction of the Committee in London has considerably exceeded the estimate; but that result need not excite surprise, when the novelty of the undertaking is considered.

Mr. Youl is of opinion that the cost of a future

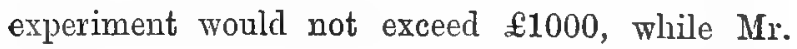
Ramsbottom estimates it at a still less amount.

R. OFFICER, Chairman. 
REPORT by Arr. William Ramsbottom on the late Eaperiment on the Introduction of SalmoN Ova into Tasmania, in his charge, by the ship "Beautiful Star."

The Beautiful Star sailed from London March 4th, with about 50,000 Salmon Ova. J. A. Youl, Esq., and Mr. Robert Ramsbottom, of Clitheroe, accompanied us to Gravesend, where we anchored for the night. The Ova and one young fry looking well.

March 5th, 1862. Steamed to Margate Roads, lay at anchor for 3 days through stress of weather. The Ova on the glass trays in the gimbal apparatus are dying in great numbers, caused by the violent rolling of the apparatus keeping them continually in motion.

8th. Weighed anchor; nearly reached the Isle of Wight when a strong head wind compels us to put back to the Downs. Remain at anchor until the 12th instant; during which time the Ova suffer greatly, both from the heavy laboring of the ship, and also from the varnish upon the Gimbal apparatus.

Up to this time the loss of Ova cannot be less than from 4000 to 5000 .

Since we put back, wrote to $\mathrm{Mr}$. Youl giving him 
all particulars respecting the serious loss of Ova and the working of the apparatus. Mr. Youl, on the receipt of my letter, came down at once to see if anything could be done for the preservation of the Ora; but I am sorry to say nothing at this time could be altered.

Mr. Youl could only recommend a strict attention to the suspended apparatus, which hitherto had worked tolerably well.

13th. Weighed anchor 9.30 P.M.; wind south east, very strong.

15th. Busy all day taking out dead Ova and removing from the glass trays those Ova which yet look moderately healthy. Wind east, strong.

16th. Putting back to the Scilly Islands for repairs to the ship, having in the night lost the plug of the propeller space. I find that the rust from the iron tanks is setting very thickly upon the Ova and gravel. Should this rust be allowed to continue, I am persuaded that the whole would be entirely buried within a month.

17th. Reach Scilly this morning. Remain until the 24th instant.

24th. Weighed anchor 12 A.r. Wind W.S.T. The loss of Ova from the 12th to this date is about 2500 .

26th. During the night of the 25th, and early this morning, a strong gale from the west. The 
ship laboured extremely, causing the apparatus to swing to and fro with such violence as to render it dangerous to approach it-the bilge-water also washing up the sides of the ship (even to the deck), some of which fell in amongst the Ova; but the Assistant, seeing it, threw a covering of blankets over the whole of the apparatus, which prevented further injury; and I have good reason to believe that little damage was done by the bilge-water, as but a very little got into the apparatus; but, with the violent tossing and rolling of the ship, and swinging of the apparatus, it is impossible to state the precise loss of Ora caused by this one gale, as I, with the Assistant, were continually picking out dead Ova for the four following days; but it could. not have been less than 7000 .

The one little Fry, which up to this time had been so lively, died, being 23 days old.

April 5th. The weather for the last few day has been much finer. 11 p.M.-Three Fry newly hatched, and looking well. Deaths of Ova for the last 5 days, about 2500.

12th. From the 5th to the 12th instant, 3 to 6 Fry have been hatched per day. At the same time, numbers died whilst hatching. Have been obliged to make use of ice, the temperature having risen 4 degrees in 5 days. It is now $54^{\circ}$ in the apparatus. 
Should have commenced using ice 5 or 6 days earlier; but, seeing the sailing qualities of the ship, feared to begin with it before it was absolutely necessary. Could calculate, at this time, on a very long passage.

17th. Loss of Ova for the past week, about 3000 . Since the 12th instant, the young Fry have all died. The last of them lived 10 days.

During the last two days have been engaged in cleaning out the whole of the Ova beds, - a work which ought never to be done if it could possibly be avoided; but, from the number of decayed Ova that were under the gravel, it was necessary, as wherever any dead Ova were allowed to remain in the gravel, those immediately above them were sure to perish.

May 7th. From the 17th April to this day, nothing of importance has occurred. Weather fine, but hot, causing much trouble to keep down the temperature of the water.

The ice cannot last much longer, at the rate necessary to use it.

The average loss of Ova from the date of cleansing the trays does not exceed 20 per day.

8th. 9 P.M.-To-night, as usual, went into the ice chamber. The ice having got very low, discovered a little box of Ova which had been bedded in it by order of J.A. Youl, Esq., before leaving London. 
On taking up the box, found that the lid was broken off, but that the Ova were well covered with moss.

8th. Had no expectation of finding living Ova (even had the box been perfect); but, on lifting up a portion of the moss in which the Ova were bedded, had the satisfaction to perceive that, amongst the many dead, there were still some living.*

Having procured a large vessel and submerged therein the whole (moss, dead and living Ova), carefully took out the moss, and poured off the greater portion of the water. Having done this, emptied the contents of the vessel into one of the trays with all the care and speed possible, keeping it apart from the other Ova; then picked out the dead Ova, about 250 in number, and had 19 living, to all appearance in good health.

This experiment will no doubt prove of much future value, as indicating a new and successful method of transporting Salmon Ova to distant countries.

9th. During last night and to-day have lost 5 of the Ova taken from the box; but no doubt the cause is from injuries received when cleaning away the moss and placing them in the tray.

11th. The ship pitching and rolling, causing the

* This box was packed by Mr. Youl as an experiment, which afterwards proved to have been the germ of success.-A. N. 
apparatus to swing so violently as to strike the beam to which it is suspended.

15th. In latitude $20^{\circ} 36^{\prime}$ S., longitude $25^{\circ} 8^{\prime} \mathrm{W}$.; wind east, calm. Ice nearly finished. With no better breeze than at present, the Ova must of necessity die.

16th. No change in weather. Have taken from the chamber the last three blocks of ice, which cannot last many hours, -10 P.M.

17th. Latitude $22^{\circ} 19^{\prime} \mathrm{S}$., longitude $25^{\circ} 55^{\prime} \mathrm{W}$. Have been allowing the temperature of the water to rise a little by degrees; but all to no purpose. Ice all melted about 12.30 A.M., and the whole of the Ova died at 1 A.M., at a temperature of $59^{\circ}$, with the exception of those that had been taken from the moss, which lived eight hours longer, at a temperature of $65^{\circ}$ (9 A.M.); being 74 days from London, and 88 days from the time of their being taken from the parent fish.

I can only add, on looking over the Journal, my extreme astonishment at the Ova surviving so long under such tremendous disadvantages.

It is useless to mention the gimbal apparatus, which was a failure from the beginning.

On the other hand, the value of the suspended apparatus, in which my only hope was placed, was 
rendered nugatory by the utterly unsuitable character of the ship.

The gale that prevailed on the 26th March (when the bilge-water washed up to the deck) caused the death of 7000 Ova placed on the surface of the gravel, as also of a great number of those deposited under it which could not then be removed, and which, by their subsequent decomposition, proved the destruction of many others.

Under all these disadvantages, it is only surprising that any of the Ova survived for so long a period as 74 days from the date of their embarkation, and 88 days from the time of their being taken from the parent fish.

The above facts show conclusively, in my opinion, that if the late experiment had been made in a roomy and fast ship, with properly constructed tanks, many thousands of the Ova would have reached their destination in safety.

WM. RAMSBOTTOM. 


\section{STATEMENT of Expenditure.}

$$
£ \text { s. } d . \& s . d \text {. }
$$

To constructing Salmon

Ponds at River Plenty $\quad 727 \quad 411$

Fencing ground round Ponds ................... $6013 \quad 0$

Salary to Mr. Ramsbottom, and Accounts paid in Hobart Town $111 \quad 6 \quad 6$ $\begin{array}{lll}899 \quad 4 & 5\end{array}$

Amount reported by $\mathrm{Mr}$.

Youl to have been paid by him in England ...

\begin{tabular}{rrr}
$1420 \quad 0$ & 0 \\
$£ 2319 \quad 4 \quad 5 *$ \\
\hline
\end{tabular}

* Mr. Black had estimated the cost at $£ 2,400$, and this was approved of by the Committee of the Tasmanian Parliament, in their Report, dated August 31, 1860.-A. N. 


\section{TASMANIA.}

\section{REPORT OF SALMON COMMIS- SIONERS, 1864.}

To His Excellency Colonel Thomas Gore Browne, C.B., Captain-General and Governor-in-Chief of the Colony of Tasmania and its Dependencies.

May it please Your Excellenct,

In the month of September, 1862, the Commissioners had the honour to report to Your Excellency that, profiting by the important lesson derived from the history of the little box of Salmon Ova embedded in moss, which had been placed in the ice-house of the Beautiful Star, as detailed in the extract from Mr. W. Ramsbottom's log appended to their Report dated August, 1862, they had resolved to send Mr. W. Ramsbottom back to England with the least possible delay, in order that he might assist in ascertaining from actual experiment for what periods the Salmon Ova 
packed in moss, and deposited in some of the ice vaults in England, might be kept in an undeveloped state and afterwards hatched into living fish.

In accordance with this determination of the Commissioners, Mr. Ramsbottom at once proceeded to Melbourne, from whence he took his departure in the steamship Great Britain, and reached England in December.

While despatching Mr. Ramsbottom to England for the purpose mentioned, the Commissioners, retaining a lively sense of the zeal and energy displayed by their fellow colonist Mr. J. A. Youl in the first attempt which they had made to introduce the Salmon into the Colony, and then recently brought to an unsuccessful conclusion, addressed a letter to that gentleman, earnestly requesting his continued co-operation in their renewed endeavour to effect this great object; and subsequently committed the direction of all that was to be done in England to the Australian Association, to whom the management of the first experiment had been entrusted, knowing that, as on the previous occasion, it would practically devolve on $\mathrm{Mr}$. Youl, one of its members.

The Australian Association accepted the trust which the Commissioners desired them to undertake, but immediately delegated to Mr. Youl "the 
sole superintendence of the necessary preparations for the renewed experiment about to be tried." How earnestly and zealously Mr. Youl discharged. the duty thus devolving upon him, will appear from our further report of his labours in this patriotic undertaking.

Immediately on Mr. Ramsbottom's arrival in England, the experiments to which the Commissioners have referred, and to the issue of which they looked forward with the deepest interest, were commenced under Mr. Youl's direction, and carried on during the year 1863.

The success of thes $\theta$ experiments fully satisfied the expectations of the Commissioners, at whose instance they were undertaken. A large proportion of the Ova that had been deposited in the Wenham Lake Company's Ice Vaults in London, for periods varying from 45 to 144 days, were found at the end of those periods to be still in a state of healthy vitality; and were afterwards hatched into vigorous fish by various pisciculturists to whom they were committed after removal from the Ice Vaults.

In the conduct of these experiments $\mathrm{Mr}$. Youl was zealously assisted by W. Ramsbottom, by his father, Mr. R. Ramsbottom, of Clitheroe, and by the Manager of the Wenham Lake Ice Company, who, on Mr. Youl's application, had generously 
granted the free use of their Vaults in London, in which they were carried on through their first stage. The result of these experiments constitutes, the Commissioners believe, one of the most valuable discoveries ever yet made in the art of pisciculture, and must ever indicate an important era in its history.

This result was no sooner communicated to the Commissioners, than they came to the conclusion that this was the method by which the Salmon was to be successfully introduced into the waters of Tasmania; and that the expensive, troublesome, and uncertain mode of conveying the Ova in suspended trays, requiring a constant stream of iced water to pass over them, might henceforth be dispensed with.

They were unanimously of opinion that, in the condition of Ova placed in an ample body of ice on board a fast vessel sailing direct to Hobart Town, the Salmon could not fail of reaching their destination in safety. This opinion the Commissioners conveyed to the Australian Association, and ras, as far as possible, carried into practical effect by Mr. Youl. That gentleman, however, found on this, as on the previous occasion, that his principal difficulty consisted in finding a vessel fulfilling all the conditions deemed necessary for the successful transport of the Ova to their destination at the 
Antipodes. One vessel only, the Alfred Hawley, was advertised to sail for Hobart Town about the period suitable for the shipment of the Ova, and, although in other respects supposed to be a smart vessel, she was of a tonnage too small to inspire confidence in her making a rapid passage.

With the owners of this ship Mr. Youl entered into and carried on negotiations until it was discovered, in the beginning of January, 1864, that, having only just returned from China, there was no hope of her cargo being discharged, and the preparations necessary for the reception of Ova completed, until too late for their shipment during that season.

In this emergency Mr. Youl acted with admirable promptitude and decision, which saved the experiment from being shipwrecked and delayed until the following year.

The Alfred Hawley, and the idea of a direct passage to Hobart Town, were immediately dismissed from his mind, and application made to Messrs. Money Wigram and Sons, the owners of the splendid and well-known clipper ship the Norfolk, then advertised to sail for Melbourne on the 20th of January, to undertake the conveyance of the Salmon Ora by that vessel.

To this application these gentlemen not only assented with alacrity, but declined to receive any 
remuneration for the important service which they undertook to perform, desiring only that it might be accepted by the Australasian Colonies as a proof of the interest which they took in the welfare and advancement of these rising communities.

When Messrs. Money Wigram and Sons first intimated their intention of making no charge for the conveyance of the Ova by the Norfolk, Mr. Youl had, in a truly liberal and patriotic spirit, undertaken to pay them One Hundred Guineas from his own pocket, if they should think fit to receive it, as some remuneration for the occupation of a twentieth part of their noble ship. Of this offer, however, these gentleman ultimately declined to avail themselves, desiring that the service should be entirely gratuitous. From copies of the letters that passed between $\mathrm{Mr}$. Youl and the owners of the Norfolk, given in the Appendix to this Report, the character of this transaction, which reflects much credit on them both, will be fully understood by your Excellency.

A space measuring fully 50 tons, equal to a twentieth part of the whole tonnage of the Norfolk, was thus gratuitously dedicated to the service of the undertaking by her public-spirited owners.

But the value of the service is not to be measured by the mere extent of tonnage occupied for the purposes of this great experiment. 
Besides the disturbance of the usual arrangements in the hold of their vessels caused by the erection of the Ice-house, shipowners appear to have entertained a fear that a leakage might take place from the Ice-house and injure the goods stowed below. From these causes, the owners of vessels who have been applied to on former occasions have demanded much higher rates of freight than they would probably have considered adequate under other circumstances.

For the conveyance of the Ice-house and swinging apparatus, with the passage of Mr. W. Ramsbottom, the sum of $£ 500$ was paid to the owners of the Beautiful Star, whose whole capacity did not much exceed 100 tons. The freight demanded by the owners of another vessel, the Zealander, with whom Mr. Youl had entered into negotiations for the conveyance of the Ova to Hobart Town on her way to New Zealand, was $£ 750$; while, for a like service by the Percy, a regular Hobart Town trader, no less a sum than $£ 1500$ was required. In this last case, however, some derangement in the usual period of sailing from London was involved.

Having thus provided for the conveyance of the Ova to Melbourne by one of the fastest ships in the Australian Trade, and having nearly completed the arrangements necessary for their reception on 
board the Norfolk, whose departure was positively to take place on the 20th of January, Mr. Youl forwarded instructions to Mr. Robert Ramsbottom, the well-known pisciculturist of Clitheroe, to procure forthwith, from the Ribble, the number of Ova intended to be dispatched to Tasmania. On former occasions Mr. Ramsbottom had never found any difficulty in obtaining whatever quantity had been required by $\mathrm{Mr}$. Youl; and in the previous year, on the 12th of January, an abundant supply of spawn had been obtained from the Ribble. A week earlier in the present year, dependent on some peculiarities of the season, every fish captured by Mr. Ramsbottom was found already to have shed its spawn in the river.

On receiving this embarrassing information from Mr. Ramsbottom, the same energy that had been called forth by the difficulty of finding a suitable means of conveyance to the Antipodes was displayed by Mr. Youl.

Mr. Ramsbottom, with his son, Mr. William Ramsbottom, were immediately dispatched to the "Dovey" in Wales, and Mr. W. Johnston, another experienced and trustworthy Pisciculturist, to the "Tyne."

At the same time, with much judgment, Mr. Youl published in the Times a general appeal to the Proprietors of Salmon Fisheries, and to all 
who were engaged in or took an interest in the work of Pisciculture throughout Great Britain, to assist in the great experiment then in hand.

That appeal was successful, and was responded to in the most liberal and generous manner by noblemen, gentlemen, and others, both in England and Scotland. Through their kind assistance, and the zeal and activity displayed by the agents employed by Mr. Youl, amongst whom Mr. Ramsbottom of Clitheroe, our Superintendent Mr. William Ramsbottom, and his brother Mr. Restab Ramsbottom, greatly distinguished themselves, the requisite supply of Ova, exceeding 100,000 in number, with several thousands of Trout Ova, were ultimately obtained.

In spite, however, of all the energy and activity that had been displayed, these Ova did not reach London until the 18th of January; nor could it have been possible to have shipped them all and completed the arrangements in the Ice-house, had not Messrs. Money Wigram \& Sons given a further proof of their generosity by detaining the Norfolk for one whole day after she was quite ready to set sail.

The history of this anxious part of the undertaking is so well given in Mr. Youl's letters to the Times, dated the 6th, 12th, and 21st of January last, that the Commissioners append them entire to their Report. 
The Commissioners have learned from a perusal of these letters, and from other communications, how deeply they are indebted to the various parties enumerated by Mr. Youl for the ready and valuable aid afforded by them during a most critical period of the experiment; and they feel assured that, by Your Excellency, the Executive Government, the Parliament and people of Tasmania, their services will be duly appreciated and gratefully acknowledged.

All difficulties having been thus successfully overcome, the Ice-house was finally closed on the evening of the 20th day of January; and the Norfolk took its departure on the following day with its precious and novel burden, towards the ultimate fate of which the attention of the whole scientific world, and of all taking an interest in the well-being of the Australasian Colonies, was anxiously directed, accompanied by Mr. W. Ramsbottom, their special custodian and guardian.

On the 15th day of April the Norfolk cast anchor in Hobson's Bay, having thus completed her voyage to the far south in the brief space of eightyfour days.

Mr. Youl had, with much judgment, consigned the Ova to the care of Mr. Edward Wilson, President of the Acclimatisation Society of Victoria, whose zeal in the cause of Acclimatisation is known 
and appreciated throughout the length and breadth of the civilised world. It was impossible to have committed the charge into abler or more zealous hands.

Before the arrival of the Norfolk at Melbourne, Mr. Wilson had applied to the Government of Victoria for the use of Her Majesty's Colonial Steamship Victoria, for the conveyance of the Ova from Hobson's Bay to Hobart Town. That application had been liberally and promptly acceded to, and the vessel ordered to be in readiness for the performance of this service the moment the arrival of the Norfolle should be announced.

Soon after the Norfolk had dropped her anchor she was boarded by Mr. Wilson and other Members of the Acclimatisation Society, in whose presence the Ice-house was unlocked by Mr. Ramsbottom, for the first time since it had been closed in the Thames.

One of the small boxes containing Salmon Ova was then forthwith opened, and to the joy of the anxious observers it was found that a considerable portion of its contents were still in a sound and promising condition.

No examination of the remaining boxes was deemed necessary ; but the most energetic measures were immediately taken for the speedy transfer of the Ova, with the remainder of the Ice amounting 
to about 12 tons, 'from the Norfolk to the hold of the Victoria. Strong wooden boxes were prepared, in each of which fifteen of the small original boxes of Ova, covered over with a considerable thickness of Ice, and enveloped in blankets, were secured. With commendable foresight these boxes were fitted up so as to admit of their being at once slung on bamboos, and thus carried by bearers from the termination of the navigable portion of the Derwent to the Ponds on the Plenty, a distance of nearly four miles; and this arrangement was, in practice, found greatly to facilitate the conveyance of the Ova over that part of the way.

Thus prepared, eleven boxes containing 170 of the original packages were carefully removed from the Norfolk to the Victoria, and deposited in a part of the hold least exposed to the injurious action of the machinery, from which they were further protected by placing stuffed pads between the boxes.

The remaining eleven boxes were retained by the Acclimatisation Society, for the purpose of being hatched in Melbourne, without exposing them to the possible accidents and certain delay involved in a second voyage, and to the tremor caused by the action of the screw, from which Mr. Youl, as well as the Commissioners, had apprehended considerable danger to the life of the Ora. In the presence of a large Ice manufactory, in 
close proximity to which the hatching box was placed by the Acclimatisation Society, and where could be obtained at all times an unlimited supply of Ice, so essential to the well-being of the Ova, that body possessed an element of success not enjoyed by the Commissioners in this Colony, whose sole dependence rested on the surplus from the Ice-house of the Norfolk. The Commissioners, therefore, cannot but regard the retention of a small portion of the Ova in Melbourne as a prudent course, and as affording an additional guarantee against the failure of this great undertaking.

All necessary arrangements having been completed on board the Victoria, that vessel took her departure for Hobart Town on the morning of the 18th of April, and dropped her anchor in the Derwent at 3 o'clock in the afternoon of the 20 th of that month.

She was immediately visited by the Commissioners present in Hobart Town; and the work of removing the Ova and Ice, now reduced to about ten tons, into a barge provided for their reception, was forthwith begun.

The zeal evinced by Captain Norman, his officers, and men, soon brought that work to a conclusion; and all was completed in less than six hours.

At 9 P.M. the barge was taken in tow by the little steamer Emu, which had been waiting all day 
ready to start at a moment's notice, having on board two of the Commissioners and Mr. Ramsbottom; and at 1 A.M. on the following morning safely reached the wharf at New Norfolk, where the barge, with its invaluable cargo, was securely moored, and carefully guarded until daylight appeared.

As soon as it was known that the Ora had reached New Norfolk, gentlemen residing in the Town and its vicinity vied with each other in their offers of assistance by their Servants and Teams. At an early hour the barge was towed from the Steam Wharf to the place of debarkation at the Falls, where from 40 to 50 bearers and ten horse teams were wailing to take a part in the transport of the Ova and Ice to the banks of the Plenty.

Five of the large cases of Ova were, without loss of time, landed from the barge; and being slung on bamboos, for which they had been prepared in Melbourne, they were placed on the shoulders of the men selected to carry them, and were, in a space of little more than two hours, safely and without the slightest accident deposited on the margin of their new home. In like manner, and with the same success, the remainder of the cases were brought up from the barge, five at a later period of the same day, and the remaining one early on the following morning. 
Some hours after the first portion of the cases had reached their destination, and after $\operatorname{som} \theta$ alterations had been made in the gravel of the hatching boxes in the ponds, Mr. Ramsbottom, zealously assisted by one of the Commissioners, Mr. Morton Allport, began the process of unpacking the Ova from the little boxes in which they had been so long imprisoned, and placing them in the limpid stream which had long been awaiting their advent. This operation was continued during the remaining part of the afternoon and a great portion of the night, and actively resumed at the dawn of the following day, in the course of which it was concluded.

This process was conducted by Mr. Ramsbottom in the most careful manner, and in the way which his experience and observation had taught him was least likely to injure the delicate and sensitive Ora.

The layer of moss, over the surface of which the Ova were scattered, was immersed in the gently flowing water of the breeding troughs, by the action of which the Ova, both dead and living, were quickly disengaged from the moss, and quietly settled down on the gravel below.

The removal of the dead Ova was a further and subsequent, as well as a laborious and delicate task, but was executed with all possible despatch. After a considerable number of the small boxes 
had been opened, and their contents examined, it was seen that the condition of the Ora varied greatly in the different packages.

While in some the greater portion of the Ova still retained their vitality and healthy aspect, in others nearly every one had perished.

After some further opportunity of observation, it was perceived by Mr. Ramsbottom and the Commissioners present, that a close and almost unvarying relation existed between the fate of the Ova and the condition of the moss in which they were enveloped.

Where the moss retained its natural green hue and elasticity, there a large proportion of the Ova retained a healthy vitality. Where, on the contrary, the moss was of a brown colour, and in a collapsed or compressed form, few of the Ova were found alive, and all were more or less entangled in a network of fungus.

The Commissioners cannot, therefore, help sus. pecting that the condition and quantity of the moss in which the Ova were imbedded in each small box greatly influenced their health and vitality. Messis. Allport and Ramsbottom, by whom the chief part of the Ova were transferred from the packing-bores to the Ponds, assured the Commissioners that the smallest amount of mortality was invariably found to have taken place in those boxes in which the 
moss had been most loosely packed, and the Ova subjected to the least amount of pressure.

The Commissioners have already communicated to Mr. Youl their observations and conclusions on this point. By him, and by other Pisciculturists in England, the subject will, doubtless, be duly investigated.

The point involved is one which experience and observation can alone decide.

It is impossible for the Commissioners to say, with accuracy, what was the number of Ova placed in the Ponds in an apparently living and healthy condition. Mr. Ramsbottom had, with some hesitation, estimated them at 30,000 , or a little more than a fourth part of the number embarked in the Norfoll.

From this number, however, it has since been discovered that a large deduction has to be made on account of those that have been found sterile in consequence of deficient fecundation. A large portion of the Ova of this character have maintained, during the whole progress of hatching, and many of them still preserve, their brilliant and healthy aspect, but on close examination are found to contain no embryo fish within.

Mr. Ramsbottom has estimated the number of these unfecundated Ova as not less than 16,000. The number of healthy Trout Ova placed in the 
Ponds is believed by Mr. Ramsbottom not to have exceeded 300 ; and his opinion is confirmed by the Commissioners present at the opening of the boxes, and other observers.

Immediately before commencing the operation of depositing the Ora in the breeding troughs at the Ponds, blocks of ice were placed in the small stream which flows over them, which had the effect of reducing the temperature of the water from $55^{\circ}$ to $44^{\circ}$. This was continued while the ice lasted,a period of two days, -and was found amply sufficient to carry the Ora safely through the critical stage of transition from the low temperature in which they had previously existed to the higher temperature of the Ponds to which they now became exposed. All danger, however, from this source, if any existed, was effectually prevented by a natural and considerable fall in the temperature which tool place in the water of the Plenty before the supply of ice had become exhausted, and which has since remained very uniform, not exceeding $49^{\circ}$ nor falling below $39^{\circ}$.

With a view to provide an additional guarantee against total failure, a portion of the Ova were subjected, in accordance with the advice of $\mathrm{Mr}$. Youl, to the process of hatching in an apparatus entirely apart from the Ponds, and consisting of two tubs filled with gravel and supplied with a 
slender stream of iced water from a large cask with which they were connected.

In this manner a small portion of ice, reserved for the purpose, was found sufficient to maintain the water at a reduced temperature for some time after it could no longer be applied to the larger apparatus connected with the Ponds.

In these tubs, however, no greater success was achieved than in the larger breeding troughs.

The Salmon Ova were deposited in the Ponds on the 91st day from the date of their embarkation on board the Norfolk; and, with the exception of the contents of two small boxes of greater age, about the 96th from their exclusion from the parent fish, and thus four days within the period beyond which it has always been represented by Mr. Youl that it would be highly dangerous to delay their immersion in their native element.

The Ova having been thus all deposited in the Ponds, it is unnecessary for the Commissioners to inform Your Excellency that their progress towards maturity was watched with intense anxiety.

Two boxes have been mentioned as containing Ova of a greater age than the others. These had been taken from the parent Salmon about the 6 th of December, 1863, had lain for six weeks in the Ice Vaults of the Wenham Lake Ice Company; and were, therefore, 45 days old at the time of em- 
barlation in the Norfolk, and 136 days when placed in our Ponds.

They had been sent out by Mr. Youl with the special object of further ascertaining for what period the process of hatching might be retarded beyond the natural period.

Of these Ova few were found to have survived, but most of those that were still living already exhibited the eyes and outlines of the fish within.

Among the others of shorter age, and especially the Trout Ova, the same encouraging proofs of development were soon perceived.

On the 4th of May (1864) the first Trout made its appearance, followed on the succeeding day by the first Salmon that had ever been seen in Australia, or south of the equator.

The further hatching of the Trout and Salmon proceeded very slowly for some days, but then became more rapid-especially among the Trout. Among these the process was completed about the 25th day of May, producing upwards of 200 healthy fish.

The hatching of the Salmon was more protracted, and was not concluded until the 8th of June, on which day the last little fish was observed malking its escape from the shell.

As they continued to make their appearance from day to day, their numbers were counted by $\mathrm{Mr}$. 
Ramsbottom with tolerable accuracy up to about 1000 , after which it was no longer possible to keep any reckoning.

It is impossible for Mr. Ramsbottom, or the Commissioners, to make even an approximate estimate of the number of young Salmon now in the Ponds. That they amount to several thousands they have no reason to doubt; and, as the mortality amongst the Ova after deposition in the Ponds was very moderate, and quite insignificant among the young fish, there is reason to hope that they may exceed rather than fall short of expectation.

Although the first living Salmon was discovered in one of the troughs containing a portion of the younger Ova, there is no doubt that it was preceded by some hatched from those of the greater age, although, from being concealed under the pebbles, they were not sooner noticed. That they had preceded the others, however, is evident from their superior size, and other marks of greater advancement. From these older Ova not more than 4 or 5 fish have been produced.

The Trout have now entirely lost their umbilical appendages, and receive their morning and evening meals of boiled liver from the hands of their keepers.

The Salmon are rapidly advancing to the same condition. 
Having been urged by Mr. Youl not to admit the Trout into the same * rivers with the Salmon, the Commissioners have clecided in the meantime to place the former in the circular clearing Pond under Mr. Ramsbottom's immediate eye and care, where they will doubtless thrive and multiply, and at no distant period afford the means of stocking all the rivers of the Colony into which it may be considered proper to introduce them.

The great undertaking of introducing the Salmon and Trout into Tasmania has now, the Commissioners believe, been successfully accomplished; and they trust they are not premature or too sanguine in congratulating Your Excellency and the Colony on this auspicious event, which cannot fail at no distant time to exert a very beneficial influence on the interests and resources of the Australian Colonies.

Few countries of the same extent possess more rivers suited to the nature and habits of this noble fish than Tasmania. A stranger acquainted with the Salmon rivers of Europe could scarcely behold the ample stream and sparkling waters of the Derwent without fancying that they were already the home of the king of fish.

* Nevertheless Trout were placed in the Plenty river, to the great risk, if not certain destruction, of the salmon fry, which might in future be bred in the river.-A. N. 
And the Derwent is but one of many other large and ever-flowing rivers almost equally suited to become the abode of the Salmon. When these rivers have been stocked, they cannot fail to become a source of considerable public revenue, and of profit and pleasure to the people.

Where so many have assisted in obtaining this important boon for the Colonies, it is difficult to particularise all those to whom it is indebted for their disinterested services.

The untiring zeal and indefatigable exertions of Mr. Youl stand forth conspicuous, and have been mainly instrumental in bringing the present experiment to a successful issue.

The noble liberality of Messrs. Money Wigram and Sons has been already dwelt on; and those gentlemen, the Commissioners are aware, have received the well-merited thanks of Your Excellency's Government.

To those Noblemen, Gentlemen, and others, who rendered such important and timely aid to $\mathrm{Mr}$. Youl in his arduous labours, the thanks of the Commissioners, and of the whole colony, are due.

A special vote of thanks has been transmitted by the Commissioners to $\mathrm{Mr}$. Robert Ramsbottom, of Clitheroe, for the untiring interest he has long manifested in the attempts to introduce the Salmon into Australia, of which he has given practical 
proof by his hearty co-operation with Mr. Youl, and the free use of his practical skill and experience in promoting the success of the experiment.

The Commissioners have felt it to be their duty, with the sanction of the Government, to present pieces of Plate, with an expression of their thanks, to Captain Tonkin, of the Norfolk, to Mr. Carpenter his Chief Officer, and to Captain Norman, of Her Majesty's Colonial Steam Ship the Victoria, in acknowledgement of the deep interest displayed by them in the success of the undertaking, and their efforts to secure the rapid transport of the Salmon Ova from London to Melbourne, and Melbourne to Tasmania, upon which their safety in a great degree depended.

This Colony is under deep obligations to the Government and Parliament of Victoria, and to the President and Members of the Acclimatisation Society, for their disinterested assistance.

Towards the expense of the experiment by the Beautiful Star, the liberal sum of Five Hundred Pounds was cheerfully contributed from the Public Treasury of that Province; and, on the recommendation of the Acclimatisation Society, a similar amount was granted in aid of the second experiment, together with the use of the fine Steam Ship Victoria.

The importance of this latter service can hardly 
be too highly estimated. It supplied a link in the progress of the experiment which had caused the Commissioners much anxiety.

The value and disinterestedness of these services are enhanced by the fact that, at the time they were rendered, the faintest hope only existed that Victoria would be benefited by the success of the undertaking except in a very secondary degree. It is only lateiy that the idea of acclimatising the Salmon in some of the rivers of that Colony has been entertained; and the Commissioners will hear with much pleasure that this reasonable expectation has been fulfilled.

They rejoice to learn that nearly three hundred healthy young Salmon have been produced from the few boxes of Ora left in the hands of the Acclimatisation Society; and it will be their first duty, as some acknowledgement of the generous aid they have received from Victoria, to render every assistance in their power towards the early stocking of the Rivers of that great Colony fitted to become the homes of the Salmon and Trout.

Since the process of hatching was completed, the mortality among the young fishes, both Salmon and Trout, has been very insignificant, and has been almost entirely confined to a small number of the former that came forth from the egg with crooked spines or some other deformity. 
They have grown considerably, and present every characteristic of vigorous health.

The Commissioners have no reason to doubt that the young Parr will, in due season, attain to the condition of complete Salmon, fulfil the longcherished hopes of the Colony, and make an ample return for all the expense and labour incurred in introducing them.

They entertain every confidence that, under the guidance of their unerring instincts, they will, when the proper time arrives, proceed to and return from the sea in safety, and in their journey will meet with no enemies more formidable than those to which their progenitors have been exposed in the waters of Great Britain.

Notwithstanding the success, however, that has already been achieved, the Commissioners are unanimously of opinion that at least one more importation of Ova should be undertaken without loss of time. It is not probable that the young fish now in the Ponds will produce any Spawn, by which their numbers may be multiplied, until a period of from two to three years has elapsed,and thus much time will be lost in fully stocking the rivers of the Colony unless a further supply of Ova be obtained.

The whole expense of another importation would not, the Commissioners believe, exceed $£ 800$; 
which, divided among the various Colonies, which they have every reason to believe would contribute towards the expense of another importation of Ova to Tasmania, from which as a centre they will be distributed to the surrounding Colonies at a very trifling additional cost, and without any risk of failure, would prove a very insignificant burden to any of them.

The undertaking can no longer be regarded as an experiment, but as a commercial transaction, to be carried out with results varying only in amount. Considerable as has been the success on the present occasion, the Commissioners believe that the additional experience which has been gained by $\mathrm{Mr}$. Youl in England, and by themselves and their intelligent Superintendent, Mr. W. Ramsbottom, in this Colony, would ensure still rnore favourable results from a renewed importation of Ova.**

Of all the Australian Colonies, New Zealand possesses a climate most nearly resembling that of Tasmania, and the greatest number of rivers that may be supposed fitted to become the habitation of the Salmon.

* Not, however, as a bale of goods, which would be an ordinary "commercial transaction." Salmon ova must be treated from first to last with scientific knowledge and individual care.-A. N. 
From Southland the liberal contribution of Two Hundred Pounds has been received in aid of the last experiment; but she alone, of all the Provinces in that extensive Colony, has hitherto given any response to the appeal long since made to them.

The Commissioners earnestly hope that Your Excellency's Government will recommend to the Parliament, now sitting, the appropriation of such a sum as will enable them to take immediate measures for the introduction of a further supply of Salmon Ova.

In the Appendix will be found a statement of the whole cost of the last importation.

The Commissioners have every reason to be satisfied with the manner in which their Superintendent, Mr. Ramsbottom, has discharged the important duties of his office. He has amply fulfilled the expectations which induced them to send him back to England in 1862 ; and since his return to the Colony, the intelligence and devotion with which he has watched and aided the progress of his valuable charge has merited their warmest commendation.

The Commissioners, anxious not to anticipate any expenditure that could be postponed until the success of the undertaking should be fully established, have hitherto refrained from recommending the erection of a residence for the Superintendent in the vicinity of the Ponds. 
That work should now no longer be delayed; and they recommend that a comfortable weatherboarded cottage should be built with all possible dispatch for the accommodation of $\mathrm{Mr}$. Ramsbottom and his family.

The thanks of the Commissioners are due to $R$. Read, Esquire, for his kind hospitality in receiving Mr. Ramsbottom (who must otherwise have lived in a tent) into his house at Redlands.

The salary hitherto paid to Mr. Ramsbotton for his services has been very small, and is, in the opinion of the Commissioners, no longer commensurate with the duties entrusted to him.

On this subject they will further address Your Excellency's Government in a separate communication.

R. OFFICER, Chairman of Commissioners.

FXPENDITURE incurred in the late successful . Experiment of introducing SaLmon Ova into Tasmania.

\& s. $d$.

Disbursements in England............. $685 \quad 12 \quad 5$

Disbursements in Melbourne, Hobart

Town, and to Salmon Ponds ........ $300 \quad 9 \quad 8$

$\$ 986 \quad 2 \quad 1$




\author{
A. 1. \\ Ship and Insurance Brokers, East India and \\ General Agents, \\ 7, Leailenhall-street, 21st January, 1864.
}

DeAR Sir,

Kindly inform us if the freight upon the Salmon Ova is to be made payable here or in the Colony, as we must fill up the Bills of Lading accordingly. The rates are $60 \mathrm{~s}$. per ton (measurement) paid in London, and 70 s. payable in the Colony.

We are, Dear Sir,

Your obedient Servants, M'LEOD, ALLPORT, \& MORGAN.

JAMes A. YouL, Esq.,

Clapham Park.

\title{
A. 2 .
}

Waratah House,

Ditar Sirs,

Clapham Park, 21st Jamuary, 1864.

Messrs. Wigram have given me the room for the Ice-house, which contains the Ova, to be supplemented however, if they deem fit, by 100 guineas from my own pocket; the Bills of Lading will, therefore, require no freight charge to be entered 
in them, except for two boxes containing apparatus gone into the hold, the freight of which will be paid here.

Yours faithfully,

JAMES A. YOUL.

To Messrs. M'Leod, Allport, \& Morgan.

SIR,

A. 3.

Blackvall Yard, London, E.,

26th January, 1864.

With reference to your offer to pay us 100 Guineas freight for the conveyance of the Salmon Ova per Norfolk to Melbourne, we wish to remind you of the extreme difficulty there is in obtaining permission to build the Ice-house in any ship, owing to the great interference it makes in stowing the cargo and general arrangements of the ship, which is materially increased when it is necessary to ship the Ice-house in a regular passenger ship; consequently, it was only the knowledge of the importance it is to the Colony to introduce the Salmon into its waters that induced us to accede to your request to give you the necessary room in the Norfolk.

The interest we feel in the Colony, and in the experiment of conveying Ova to distant places, induced us to afford you the facilities you required; 
and in the same feeling, we are willing to waive our right to the amount you agreed to pay us for freight, on the understanding that you will communicate this to the respective Governments of Melbourne and Tasmania, and in so doing, convince them of the importance we attach to the well-being of those Colonies, and the hope that we have that our endeavours for their general benefit will not be overlooked in the general arrangements they may respectively make.

Hoping the experiment may be successful,

We remain,

Your obedient Servants,

MONEY WIGRAM \& SONS.

J. A. Your, Esq.

\section{SALMON TO AUSTRALIA.}

Sir,

To the Editor of the Times.

When people are in distress the most effectual means of getting relief is an appeal to the public through your columns, which I believe every sane man who has the time and opportunity reads; and as I have just now most unexpectedly met with a great difficulty in my endeavours to carry out a national undertaking, in which I have no pecuniary interest, I trust you will give me the desired aid. 
After two attempts to introduce Salmon into Australia, the last of which failed from the unsuitableness of the vessel in which I was compelled to place the Ova, at the request of the Government of Tasmania I have undertaken the charge of malking a third experiment this year; and by the noble generosity of Messrs. Money Wigram \& Sons, the eminent Shipbuilders of Blackwall, who have given me room in one of their best and fastest ships, the Norfolk, to sail on the 20th inst., the greatest difficulty I have had to success-a good ship-has been overcome.

I had nearly completed all my arrangements on board for the reception of the Ova, when to my great dismay this morning I received a note from Mr. Ramsbottom, of Clitheroe, whom I have always employed to obtain the Ova for me, saying that every Salmon he had caught in the Ribble had already spawned. What was he to do? On the 12th of January last he obtained plenty of spawn from this stream, and I had depended on getting my supply from it again this year.

I therefore directed him to start off immediately to North Wales to try and get some Ova from the Dovey, where on two previous occasions in February he obtained large numbers for me. I have also sent Mr. William Johnston to Newcastle-on-Tyne to endeavour to get some Salmon from that river. 
I am, however, so pressed for time that I take the liberty of appealing to the proprietors of the Dovey and Tyne to be so kind as again to afford to Mr. Ramsbottom and Mr. Johnston all the assistance in their power to enable them to take Salmon, as well as to any of your readers who many be in a position to help me with unspawned Salmon, so that I may not lose the only chance I ever had of fairly trying to get this noble fish out to Australia - viz., a roomy, fast-sailing, first-class ship.

\section{I am, Sir,}

Your obedient Servant,

Waratah House, Clapham. Park,

\section{JAMES A. YOUL.} January 6, 1864.

\section{SALMON OVA TO AUSTRALIA.}

Sir,

To the Editor of the Times.

I beg leave to return my best thanks to those noblemen and gentlemen who so promptly acceded to my request made through your columns for permission to take unspawned Salmon out of their rivers for the purpose of transmitting the Ora to Australia. I have also to thank Mr. Ffennell, the Chief Commissioner of Salmon Fisheries for Eng- 
land; Mr. John Morrison, agent for New Zealand ; Mr. Frank Buckland, Mr. Sackville Phelps, of Machynlleth, North Wales; Mr. Edward Glynn, of Newcastle-on-Tyne; Mr. Richard Gibson, of Hexham; Mr. Patrick Clay, of Berwick-on-Tweed, \&c., for the personal aid they have given me; and to Mr. Thomas Ashworth for his generous offer of Ova from his own breeding-ponds at Galway, which, however, I am afraid to accept, as they have been for some time deposited.

$$
\text { I am, Sir, }
$$

Your obedient Servant,

JAMES A. YOUL.

Waratah House, Clapham Park,

$$
\text { January 12, } 1864 .
$$

P.S.-Mr. Ramsbottom has caught a good many fine unspawned Salmon, but, the Ora not being ripe enough to take, they were returned to the stream again. No Ova have yet been obtained for me.

\section{SALMON AND TROUT OVA FOR AUSTRALIA.}

SIR,

To the Editor of the Times.

I have received a great many letters from gentlemen offering assistance to obtain. Salmon Ova, but my being so much occupied on board the 
Norfolk has prevented me from answering them. I think the most grateful return I can now make to those who have evinced such deep interest in the undertaking will be to give a very brief account of our proceedings; but, before doing so, I have also to tender my thanks to those gentlemen living near the Tyne, the Tweed and Ettrick, the Ribble, the Teme and Severn, and the Dovey Rivers, who not only gave permission to those employed, but energetically aided them in obtaining ripe fish from these streams.

Notwithstanding all the efforts made by the fishermen, we were unable to obtain a single ripe fish so long as the severe frost lasted, which appears to have prevented the spawning fish from leaving the sea and ascending the tributaries of the larger rivers to deposit their spawn.

This bears out the opinion expressed very recently by Mr. Frank Buckland, "that the Salmon is a very knowing fish," and would not, therefore, quit the estuaries so long as the spawning beds were frozen and unfit for the reception of the Ova.

At one time I nearly despaired of success, as the ship was positively to leave the Docks on the morning of the 20th. Up to the evening of the 14th no Ora had been obtained, but within 24 hours of that time the fishermen employed in Scotland, Lancashire, Worcestershire, and Wales simul- 
taneously obtained ripe fish, full of spawn, which had evidently ascended the rivers a few days after the breaking up of the frost. It is a very singular coincidence that these men, who had not the slightest communication with each other (their orders being simply to come up to London by first train as soon as they had obtained 20,000 ), all arrived laden with 0 va between 5 A.M. and 10 A.M. on Monday, the 18th instant.

The East India Dock Company having lkindly placed at my disposal a large space in one of their sheds within a few yards of the Norfolk, I had beforehand made such preparations as enabled me to pack and place safely in the ice-house by 4 P.M. all the Ova obtained.'

The boxes in which the Ova are packed are made of inch pine, $11 \frac{3}{4}$ inches long, $8 \frac{3}{4}$ wide, and $5 \frac{1}{4}$ deep, perforated with holes top, bottom, and sides, to allow the water from the ice as it melts to flow into the boxes, and percolate through the moss and Ova inside.

The manner of packing is as follows:-A couple of handfuls of charcoal are spread over the bottom of the box, then a layer of broken ice, after this a bed or nest of wet moss is carefully made and well drenched with water; the Ova are then very gently poured from a bottle which is kept filled with water; the box is now filled up with moss, and pure water 
poured upon it, until it streams out from all the holes; another layer of finely pulverized ice is spread all over the top of the moss; the lid is then firmly screwed down. As soon as this process is completed it is most desirable, in my opinion, that the boxes should be placed in immediate contact with ice. One hundred and sixty-four boxes, containing above 90,000 Ova so treated, were firmly packed at the bottom of the ice-house, covering the entire space. Upon these a solid mass of ice was piled, to the height of $9 \mathrm{ft}$., so that as long as any ice remained the Ova would derive benefit from it. Sixteen more boxes were placed in other parts of the ice-house, making a total of 181 boxes, containing about 100,000 Salmon and 3000 Trout Ova.

I have to thank Admiral Keppel, of Bishopstoke, for a handsome present of 1000 Trout Ova, which I received through Mr. Frank Buckland, and which were stowed at the bottom of the ice-house. I also received from Mr. Francis Francis two separate lots of Trout Ova, which I placed in the centre of the ice-house.

I think it is due to Messrs. Money Wigram and Sons to state that, had they not most courteously delayed the departure of their vessel for one whole day-viz., from the morning of the 20th to the morning of the 21st, on my sole account, and 
given every facility for getting the ice on board, it would have been impossible for me to complete the arrangements for the transmission of the Ova; in proof of which, although every exertion was made, the last block of ice was not on board until four o'clock yesterday afternoon. The total space occupied by the ice-house amounts to nearly 50 tons, 1-20th of the burden of the noble ship, a princely gift which I trust the Australian Legislatures will suitably acknowledge.

In conclusion, I feel confident your readers will most cordially join with me in wishing the good ship Norfolk a safe and speedy voyage, and in hoping that these precious little globules may retain their vitality in their damp mossy bed until they arrive at the sunny clime and golden shores of Australia; so that when placed in their native element they may come forth leaping with delight in the limpid waters of the beautiful river Derwent, notwithstanding the very cold reception they have met with from your greatly obliged and obedient Servant,

\section{JAMES A. YOUL.}

Waratah House, Clapham Park, January 21, 1864. 
[Copies of three Letters from Mr. R. Ramsbottom, of Clitheroe, to $M r$. James A. Youl.]

No. 1.

Dear Sir,

Clitheroe, November 8, 1862.

I have your letter this morning, and can get you Ova in this neighbourhood at any time between this time and the end of December, by your writing to one or two of our proprietors, which I will mention at the time you want it.

We have Salmon spawning in every stream at present, and shall have to the end of next month, and even after that time. The first spawn I got in Ireland last year was the last week in November. The west of Ireland salmon is about a fortnight or three weeks later then we have them in this neighbourhood. All I wish is, that you understood Salmon spawn as well as I do myself. You might as well try to fetch Australia to England as to carry spawn to it in moss. Salmon spawn must either be hatching or dying from the moment it leaves the fish. You can retard it to about 140 days by a low temperature, but no longer, and you can hasten the progress by a high temperature, and hatch them in from thirty to forty days, and that is just what you can do; but neither one man nor another can carry living Ova to Australia in 
any way. I have found out more than ever I knew before, and I am confident that spawn cannot be taken. You can send young fish, but that is all.

Yours very truly,

R. RAMSBOTTOM.

Mr. Yous.

\section{No. 2.}

Clitheroe, December 4, 1862.

DeAr Sir,

I have received yours this morning, and in reply beg to say that I shall be able to get you some spawn at the time you mention, providing you write to a person for permission at the time when I should get it. The name I will mention at the time, according to whose I think will be the best place at that season; it might be that I could get it near home, or I might have to go ten miles for it. We shall see at the time.

I got a splendid belly last night, and have put it to hatch at the back of my house. You cannot tell how glad I was when I met my son at Liverpool. I had once given up all thought of ever seeing him again. $\mathrm{He}$ is going to write to you in a day or two. I want you to remember what I am going to say about sending spawn in moss and ice, that is, it will not answer. If you stop the process 
of hatching you kill the spawn; you may retard but not stop it, and you can hasten but not too quick. When you have handled spawn as long as I have done you will find it a tedious kind of stuff. I don't think yet that it is possible to transport it to Australia; but I am going to try an apparatus, and if it fail I shall have spent all my faith in sending spawn. We can send young fish, but I doubt the spawn in any way.

\section{I am, dear Sir,}

Yours very truly,

R. RAMSBOTTOM.

MR, Yout.

\section{No. 3.}

Clitheroe, August 15, 1864.

Dear Sir,

Glorious news from Tasmania, over 2000 fish alive. Now you will recollect that $I$ established a Salmon fishery from 500 fry, and out of that number of marked fry I got 128 of them back as Grilse, so that you must conclude that the thing is now certain, and you must allow me to congratulate you for this success, as $I$ shall never attribute the ice question to any soul but yourself, and I should not like you to suffer any one to rob or even join you at that honour.

No one can tell how happy I feel this morning 
for this glorious success. Let me advise you to persuade the Tasmanian Government to make a special pond for the Trout, with a stream into it forty or fifty yards long, and to keep them as breeding fish, constantly in it, for the purpose of taking the spawn from them and floating it in any stream they may wish, as the trout alone are worth all the money that has been spent, and a special pond is worth making for them, as they have not to go to sea, but are at home wherever they are planted.

I have hatched 700 Char since I last saw you, and this spawn can be sent same as Salmon and Trout, so you can send all our good fish out, as well as one.

$$
\begin{aligned}
& \text { I am, dear Sir, } \\
& \text { Yours very truly, } \\
& \text { R. RAMSBOTTOM. }
\end{aligned}
$$

Mr. Youl.

$$
\begin{aligned}
& \text { Tasmania, Colonial Secrętary's Office, } \\
& \text { 23rd March, } 1864 .
\end{aligned}
$$

Srr,

I beg to acknowledge the receipt of your letter of the 20th January, containing the welcome intelligence that you had so far succeeded in the important experiment to which you have devoted so 
much time and attention. The Government fully appreciate the untiring energy which you have exhibited in the endeavour to introduce Salmon Ova into Tasmania, and they trust that the plan now adopted, the result of such careful experiments, may be crowned with that success you have so justly earned.

The Commissioners appointed to receive the Ova are maling every preparation; and I have no doubt but that the President of the Acclimatisation Society in Melbourne will afford every possible assistance to secure their safe transport to this Colony.

I have addressed a letter to Messieurs Money Wigram and Sons by this mail, thanking them for the very liberal assistance they have rendered in this affaix, which now certainly assumes a more hopeful aspect than at any previous period.

Irrespective, however, of the result, the Government desire to convey to you their cordial thanks for the active part you have taken in an enterprise fraught with such important consequences to all the Australian colonies.

I have the honour to be, Sir, Your very obedient servant,

JAMES WHYTE, Colonial Secretary. 
P.S.-Your request respecting the due recording in this office of the several enclosures, shall be carefully attended to.

To James A. Your, Esq.,

Waratah House,

Clapham Park, near London.

Tasmania, Colonial Secretary's Office,

Sir,

28rd April, 1864.

I beg to acknowledge the receipt of your letters of the 26th February; that addressed to Dr. Officer I handed to him after perusal.

You will receive by this Mail from the Commissioners full accounts of the safe arrival of the Salmon Ova, and their deposit in the prepared ponds on the River Plenty, above New Norfolk.

It affords me great pleasure to be able to offer you my sincere congratulations upon the success of this most interesting and important experiment; and on behalf of myself and colleagues I beg to convey to you the thanks of the Government and the Colonists of Tasmania for your unwearied exertions in combatting with the difficulties which opposed you at every step, and thus finally enabling me to communicate the gratifying intelligence that success had crowned your endearours. 
By last Mail I conreyed to Messrs. Money Wigram and Co. the thanks of the Government for their great liberality in placing so large an amount of freightage at your disposal; and should it be in my power to adopt the suggestion contained in your letter I shall be glad to do so, but I am not sure that it is feasible.

To the prompt and valuable assistance of the Acclimatisation Society of Victoria, and the anxiety which the Government of that Colony evinced to promote the success of the experiment by placing their Sloop-of-War at the disposal of the Society for the conveyance of the Ova from Melbourne, we are much indebted for the fortunate result; and I trust that under the fostering care of Mr. Ramsbottom, and the watchful attention of the Commissioners, we may before long find the waters of the Tasmanian Rivers abounding in this noble fish.

I have the honor to be, Sir,

Your very obedient Servant,

JAMES WHYTE,

Colonial Secretary of Tasmania.

James A. Youl, Esq.,

Waratah House,

Clapham Park, London. 
Chief Secretary's Office, Melbourne,

25 th April, 1864.

SIR,

I have the honour to acknowledge the receipt of your letter of the 26th February last, intimating the shipment of a large quantity of Salmon Ova per the Norfolk, in which vessel fifty tons of space were generously placed at your disposal by Messrs. Money Wigram and Sons.

I beg that you will accept the thanks of this Government for the important services you have personally rendered to the Australian Colonies in connection with this important matter, and that you will be so good as to convey to the Gentlemen who have so nobly assisted in the work, the assurance that their liberality is very highly appreciated.

I feel obliged by the suggestion as to the Geological Specimens, and it will afford me much pleasure to secure for Mr. Wigram a Collection illustrative of the Colony of Victoria.

I shall see that they are dispatched by one of the ships belonging to the firm at an early date.

I have the honour to be, Sir,

Your obedient servant,

JAMES McCULLOCH,

Colonial Secretary of Victoria.

J AMIES A. Your, Esq., Waratah House,

Claphan Park, London. 
Acclimatisation Society's Office, 30, Swanston Street, Melbourne,

Sir, May $26 t h, 1864$.

I have the honour to bring under your notice the following resolution, passed unanimously by the Acclimatisation Society of Victoria at a meeting held on the 25th inst.

"The Acclimatisation Society of Victoria takes this opportunity of recording its sense of the deep obligation which not only the Society, but the whole of the Australian colonies are under to James A. Youl, Esq., for his constant and undaunted determination to introduce the Salmon to these colonies; and in congratulating him upon the brilliant success obtained from the experiment made on board the Norfolk, the Society wishes distinctly to ascribe that success to Mr. Youl's persevering, enlightened, and patriotic efforts.

I have the honour to be, Sir,

Your most obedient Servant,

GEO. SPRIGG,

To James A. Youl, Esq.,

Secretary.

Waratah House,

Clapham Park, London, 
MY DEAR YouL,

Tasmania, 22nd April, 1864.

I congratulate you heartily on the success of your grand Salmon experiment. The Ova have arrived in Hobart Town alive; and, at the time I am writing, are probably in the ponds above New Norfolk. We are all eating salmon in imagination, and I trust that you will receive that acknowledgment of your exertions to which a man is always considered entitled by success.

There has been an attempt on the part of the Commissioners here-or some of them-to ascribe the merit of the experiment with ice to young Ramsbottom; but I have pointed out to the Colonial Secretary, to Davies of the Mercury, and others, the essential difference between his plan and yours. Old Dr. Gaunt said to me the other day, "You see" I was right after all." I told him that he was entirely mistaken, for that his proposal had been mooted by me in 1857 or 1858 , and that Professor Huxley had condemned it, and that it was not the plan which you had adopted at all. He spluttered and talked, but could not get over the poser which I had put to him-that he wanted to bring the Ova out frozen, which would not have left a single ovum alive.

Yours very truly,

WILLIAM ARCHER, M.L.C. 
Melbourne, 26th May, 1864.

My dear Youl,

The salmon is safe, and your statue is secure. It will be erected over the future fish-market in Hobart Town, and you are to be in the attitude of the Medicean Venus, with a salmon instead of a dolphin.

Ours are hatching out, a hurricane-about thirty or forty a day. We have had great mortality amongst the ova, arising, as we believe, from unimpregnation or injury on the voyage. Nothing could have worked better than our arrangements. Our little fish, now about 150 or 160, are very strong and healthy, rapidly absorbing their umbilical apparatus, and we have not lost one. TVe hope for a good many more births, and calculate upon between 200 and 300 fish. I think Dr. Officer rather over-estimates their probable numbers. My own idea is that they will get 5000 or 6000 which will do the work.

At any rate you may congratulate yourself upon a brilliant triumph, and the fact that you have not lived in vain.

My eyes are failing me, and I cannot write long letters. Indeed I ought not to write this. But still my heart is in the cause; and even with one foot in the grave and the other in a pan of salmon ova, I say hurrah for the principle, and three cheers 
for Youl and the Norfolk and Money Wigram and Ramsbottom.

Let us acclimatise everything but felons, and those let us repel by all constitutional means if those will answer, if not by means unconstitutional, which ferocious sentiments pray do not breathe in the sacred precincts of "the Conservatives." But let your old women beware! The wrongs that alienated the United States were tarts and cheesecakes to these. If Gardiner is permanently acquitted he is to be bribed to go home, and I shall specially direct his attention to Clapham and its vicinity.

$$
\begin{aligned}
& \text { I am, dear Youl, } \\
& \text { Yours very sincerely, } \\
& \text { EDWARD WILSON. }
\end{aligned}
$$

$$
\begin{aligned}
& \text { "Argus" Office, } \\
& \text { 25th April, } 1864 .
\end{aligned}
$$

My dear Youl,

I cannot resist congratulating you most sincerely on the success of the Salmon Ora experiment. Accounts from Hobart Town pronounce it a grand success. The honour is all your own. No other man whom I know would have stuck to the matter through evil and good report as you have 
done. When McArthur and his Merinos will be so mixed up together as that you can't separate the grain from the chaff, Youl and his Salmon will go hand in hand down to the last of posterity in Australia.

Believe me, my dear Youl, that no man in Australia rejoices more at the success you have achieved than

Your sincere friend,

L. MACKINNON.*

J. A. Yout, Esq.

* Mr. Lachlan Mackinnon was a subscriber of $£ 40$ 10s. to the fund raised to make the first shipment of Salmon Ora to the Antipodes in 1861. He subsequently went to Paris for the purpose of obtaining the advice of $\mathrm{M}$. Coste as to the best means to be adopted in the next shipment, and also to Belgium to consult rith M. Scham, another celebrated pisciculturist; and became acquainted, in his capacity of Hon. Secretary and Treasurer to the Australian Association, with all the details of the shipments by Beautiful Star and Norfolk-the government of Tasmania having eutrusted the conduct of future shipments of Salmon Ova to Tasmania to this Association,-A. N. 


\section{IMPORTATION OF SALMON.}

\section{REPORT OF THE COMMISSIONERS.}

To His Excellency Colonel Thomas Gore Browne, C.B., Captain-General and Governor-in-Chief of the Colony of Tasmania and its Dependencies.

May it please Your Excellency,

In their Report addressed to Your Excellency in the year 1864, the Commissioners expressed their unanimous opinion that, notwithstanding the considerable amount of success that had attended their recent attempt to introduce the Salmon and Trout into the Colony, resulting in the hatching of several thousands of the former and five hundred of the latter, they should be authorised to procure another importation of Ova, which they considered still necessary for ensuring the ultimate success of the undertaking, which they could not regard as complete until crowned by the return of some of the Salmon from the sea; and with the view of accelerating the full stocking of our numerous fine Rivers with these invaluable fish. 
To this proposition the Government and Parliament promptly and liberally assented; and the sum of $£ 800$ having been placed at their disposal, the Commissioners lost no time in taking measures for the performance of the task assigned to them.

They made immediate application to $\mathrm{Mr}$. James Youl, who had so zealously and successfully conducted the previous shipment of Ora, and whose co-operation they regarded as almost indispensable to success, soliciting him again to afford them his valuable assistance, and not doubting his ready compliance.

In this expectation, however, the Commissioners were disappointed: Mr. Youl declined to engage again in a work which had already cost him much personal labour and anxiety; and as his reply was not received until it was too late to make other arrangements for carrying out their object during that year, the season was thus lost to them.

Under this diffeulty and disappointment, the Commissioners, in concert with the Council of the Acclimatisation Society of Victoria, who had always cordially co-operated with them in this important work, determined to seek the aid of Mr. Edward Wilson, then resident in England, who had always taken a warm and practical interest in our previous attempts to introduce the Salmon into the Rivers of Australia. 
Although then labouring under an almost total loss of sight, since happily in a great measure restored, Mr. Wilson did not decline the task which he was solicited to undertake.

The Commissioners had no desire that Mr. Wilson should, and no expectation that he could, do more than appoint fitting agents to perform the work required; but even this was a labour which must have proved difficult and embarrassing to one suffering under such a privation. Happily, however, he was relieved from all embarrassment by the spontaneous offer of Mr. Youl again to undertake, on behalf of his friend, the whole management of another shipment of Ova.

The Commissioners need not assure Your Excellency that they received the intelligence that $\mathrm{Mr}$. Youl had thus again devoted himself to the work with much satisfaction.

They felt assured that the skill and energy that had contributed so much to the success of the former enterprise would not be wanting to the renewed undertaking; but aided by the experience acquired on that occasion, and during the interval of two years that had since passed away, would ensure a higher success than had attended any of their previous efforts.

In this expectation the Commissioners have not been disappointed. 
Mr. Youl's first work was to secure proper accommodation, paying the usual rate for freight, on board the fine clipper ship Lincolnshire, the property of Messrs. Money Wigram \& Sons, whose vessel, the Norfoll, brought out the Ora in 1864, which was advertised to sail for Melbourne at a date suitable for his purpose.

In the hold of this vessel an Ice-house was constructed, on the same general plan as that used in the Norfolk, but of rather larger dimensions, and with some improvements which experience led Mr. Youl to adopt.

The Salmon and Salmon Trout Ova were obtained from various rivers in Great Britain, through the ageney of Messrs. Ramsbottom, Johnson, and Allies, who exerted themselves most zealously to fulfil their task, rendered peculiarly arduous by the stormy weather that prevailed while they were engaged in their work, and greatly impeded the capture of the parent fish.

Mr. Youl draws the special attention of the Commissioners to the merits and exertions of $\mathrm{Mr}$. Thomas Johnson, by whom a very large proportion of the Ova were obtained and brought to London, without which the number required for shipment would have been greatly deficient.

The Ice-house was fitted for the reception of 150,000 Ova, which it was Mr. Youl's desire and 
intention to have placed in it; but, from the cause above mentioned, he was unable, in spite of the utmost efforts of himself and his assistants, to procure more than 104,000 , consisting of about 93,000 Salmon, 10,000 Salmon Trout, and 500 Brown Trout Ova.

These having been carefully packed in moss, and placed in small wooden boxes, of the same character and dimensions as those used on a former occasion, were then deposited in the Ice-house, covered by and distributed through a mass of 35 tons of ice obtained from the vaults of the Wenham Lake Ice Company.

The door of the Ice-house was then closed, not to be opened until the Lincolnshire reached her destination at the Antipodes.

The ship took her departure on the 20th January, the same day of the same month on which the Norfolk had sailed with her former shipment in 1864, with every prospect, from her well-known sailing qualities, of making a speedy voyage.

Unfortunately, in passing through the Downs, she came into collision with another vessel, and suffered so much damage as to be compelled to turn to port for repairs, thus greatly retarding her passage to Victoria.

This unfortunate accident caused Mr. Youl much anxiety, nor was it less a source of regret and 
alarm to the Commissioners when they were apprised of the disaster. Both were fully aware that the Ova could not be detained in their ice prison, as it then appeared certain they would be, for more than 100 days, without danger and loss.

The repairs of the ship having been completed, she again started on her long royage, and safely reached Melbourne on the 1st May, after a favourable passage of average duration, but extending to 100 days from the date of her first setting sail.

On the arrival of the Lincolnshire in Hobson's Bay, Mr. Ramsbottom, the Superintendent of our Breeding Establishment at the Plenty, whom the Commissioners had despatched to Melbourne some time before, for the purpose of superintending the transhipment of the Ova into the Victoria steamship, which the Government of Victoria had with the utmost liberality again placed at the service of the Commissioners, immediately proceeded on board, accompanied by the President and other Members of the Council of the Victorian Acclimatisation Society.

Two of the small packages of Salmon Ova having been anxiously inspected by these gentlemen, they were gratified by discovering that a large proportion of them appeared to be in a sound and healthy condition, notwithstanding the long and disastrous royage to which they had been exposer. 
The most energetic measures were immediately adopted for the removal of the Ova to the Victoria, in effecting which Mr. Ramsbottom was cordially assisted by the Council of the Acclimatisation Society and their Secretary, Mr. Sprigg, as well as by Captain Norman, who had afforded every facility and aid within his power for making the necessary preparations for the conveyance of the Ova to Tasmania in the vessel under his command.

The small boxes containing the Ova were packed as before in large cases, but of only half the size of those on the former occasion, which had been found too ponderous to be conveniently or easily carried from New Norfolk to the Plenty.

Although the Council of the Victorian Acclimatisation Society had borne a considerable share of the enterprise, they liberally, and the Commissioners consider wisely, refrained from detaining any of the Salmon or Salmon Trout Ova to be hatched under their own care, preferring that they should have the advantage of the more complete and matured appliances at our command, with the skill and experience of our Superintendent.

The small box containing the Brown Trout Ova was alone left in their charge, and these, when examined, were unfortunately found to have all perished.

The cases containing the Salmon and Salmon 
Trout Ova having been all securely placed in the hold of the Victoria, and covered over with the remnant of Ice from the Lincolnshire, still amounting to about 15 tons, within 24 hours after they reached Melbourne Captain Norman got up steam and proceeded on his voyage across the Straits; but, in order to obviate the danger to be apprehended from the vibration caused by the machinery, using only half steam power.

This precaution must have necessarily prolonged the passage to a considerable extent; but it was unfortunately still further protracted by a dense fog that prevailed in the Straits compelling Captain Norman, for the safety of his ship and all she had on board, to proceed with the utmost caution, and even to cast anchor under Goose Island for the greater part of one night. The passage from Hobson's Bay to the Derwent thus occupied three days instead of 40 hours, in which it is usually performed by the Steamers trading between these two ports.

From Hobart Town the Ova were promptly conveyed, together with about 10 tons of Ice that still remained undissolved, to their future home at the Plenty, by means almost precisely the same as those employed in 1864, and which it is therefore unnecessary again to describe in detail.

Within 30 hours from the arrival of the Victoria 
at Hobart Town, the whole of the Ova had been safely deposited in the hatching boxes at the Ponds.

As soon as the first boxes reached their destination, the process of unpacking was commenced by $\mathrm{Mr}$. Ramsbottom, assisted by or in presence of several of the Commissioners and many other anxious spectators.

The first two packages opened presented a very discouraging aspect. In these nearly all the Ova had perished.

As the work, proceeded, however, better indications appeared, and when all the boxes had been unpacked the general conclusion was that nearly half, and certainly not less than 40 per cent., of the Ova were to all appearance alive.

Although these results were highly encouraging, and gave promise of a large degree of success, the Commissioners and their Superintendent were fully aware that the number of fish might fall far short of the number of Ova that reached their hands in an apparently sound condition.

The appearance of the Ova that had perished indicated that by far the largest portion of the mortality had taken place within a very recent period, and led to the conclusion that they had been dying in large and daily increasing numbers for a week or two before their arrival at the Ponds.

Nor was it to be expected that this mortality 
would be immediately stayed by the removal of the still living Ova from their late unnatural home to the waters of the Pond. It was scarcely to be doubted that in many the process of decay had already begun, although not to be detected by the eye. The Commissioners were further aware, from their own experience as well as from that of all Pisciculturists in Europe, that a considerable reduction has always to be made on account of imperfect fecundation, against which no care or skill can fully provide.

Among the Ova imported by the Commissioners in 1864 , it was found that 16,000 were thus barren, and out of our recent importation 10,000 at least have been ultimately found to be in the same condition.

The number of Ova, therefore, received at the Ponds capable, under any circumstances, of producing living fish was reduced to 30,000 .

From these 30,000 Ova that had travelled over. half the circumference of the Globe before they reached our Ponds, and had been unnaturally immersed in their little wooden prisons for 104 days, we have obtained about 7000 healthy young fish, consisting of 6000 Salmon and 1000 sea Trout - a number not only large in itself, but representing a percentage not very far short of that attained at Henningen, the best conducted Fish-breeding 
Establishment in the world, where the Ova are received without having passed through any of the perils and disasters to which these had been exposed.

It will have been observed that, while only about 3000 fish were produced from the importation of Ova in 1864, more than double that number have been hatched from about the same number of Ova received on the last occasion, although fourteen days longer on shipboard.

This discrepancy in the results of the two undertakings, and the great success of the last, are probably in a great measure due to the lighter packing of the moss in which the Ova were embedded, and to some improvements in the Icehouse; to both of which Mr. Youl was led by his previous experience.

A portion of this higher success is also to be attributed to some alterations in the hatching boxes at the Ponds, consisting chiefly of the substitution of a finer for a coarser gravel, by which the Ova were prevented from ever sinking out of view, enabling Mr. Ramsbottom at once to remove all that died, and become a source of danger to the living during the process of hatehing.

The temperature of the water also, which was several degrees lower in the month of May last than 
during the same season in 1864, had no doubt a favourable influence on the result.

The young Salmon and Salmon Trout have already in a great measure been freed from their umbilical appendages, and have become vigorous and active fish. The mortality since the process of hatching was completed has been of the most trivial amount.

The Commissioners regard the Salmon Trout as an acquisition especially valuable. These fish nearly approach the true Salmon in the size to which they attain, as well as in their qualities as an article of food; and it is now a well-ascertained fact that they will thrive and multiply their numbers in fresh water without visiting the Sea.

The Commissioners, therefore, entertain no doubt that they will be as successful in acclimatising this valuable fish as they have already been in the case of the Brown Trout. The number of these last, hatched from the Ova imported in 1864, were for some time estimated not to exceed 150 , but were afterwards, when captured and accurately counted, found to approach to double that number.

Of these, about 40 were set at large in the Plenty in April, 1865, and the rest retained in the Pond as a breeding stock, where they have thriven without interruption, and have attained a size and weight excceding the standard which the Trout 
usually reaches at the same age in the rivers of Great Britain.

For several months past it has been ascertained that some of these fish would spawn during the present winter season.

This expectation has now been fulfilled, and the Commissioners have the pleasure of reporting that a considerable number of Ova have already been secured from a few of the Trout, and that others are on the point of spawning.

The Commissioners cannot say with any certainty what will be the number of Ova which the present season may yield, but from so small a body of fish in the first year of their spawning the produce will necessarily be limited.

They hope, however, to be enabled to furnish an immediate supply to the Council of the Victorian Acclimatisation Society, and to the Association lately formed at Launceston for procuring the early stocking of the rivers on the northern division of the Colony, who have given a guarantee that suitable preparation shall be made for the safety and due hatching of the Ova that may be entrusted to them.

The Provinces of Canterbury and Southland in New Zealand, from both of which pecuniary contributions have been received in aid of the undertaking, as stated in their last Report, have a just claim to 
share in the benefit of our success, which the Commissioners gladly acknowledge, and which it will be their anxious desire to gratify at the earliest possible opportunity.

At Christchurch a Pond and hatching boxes have long since been constructed under the superintendence of Mr. Johnson, Secretary to the Acclimatisation Society of that place. This gentleman has further offered to come in person to this Colony for the purpose of receiving and conveying to Christchurch such supply of Ova as the Commissioners may be able to furnish, and which it will afford them much gratification to provide during the season, if the numbers of Ova at their disposal should prove sufficient.

The claims of other localities will be attended to as rapidly as possible according to the means which may be at the command of the Commissioners.

In another year a much increased number of Ova may be expected from the same fish; and in the meantime other centres of supply will have been established, from which Ova or Fry may be distributed in all directions.

It may be expected, according to the preponderance of authority on that long disputed question -the duration of the stay of the Salmon in the sea-that the fish produced from the hatching of 1864 will return to the neighbourhood of their 
birthplace towards the end of the present year, when their arrival will be anxiously looked for as the happy consummation of this great enterprise.

The English Trout may be now regarded as established in our rivers beyond all risk of failure; and the Commissioners entertain a confident belief that the young Salmon already set at large in the Derwent, with the still larger number which they have lately succeeded in hatching and, are now thriving in the Ponds, would suffice for the ultimate stocking of our waters with this still more valuable fish.

At the same time, their opinion that this great work should never be regarded as fully accomplished until the fish have returned from the sea, and provided the means of further propagation, remains unchanged. They therefore very earnestly recommend that they should be authorised and enabled to procure at least one more importation of Ova from England, which would not only give a further guarantee against ultimate failure, but would greatly accelerate the full stocking of the rivers of the Colony, and the early realisation of the vast benefits that cannot fail to flow from the accomplishment of this great work.

When the almost incalculable value of the Salmon and Trout-as articles of human food, as a means of extending our commerce, increasing our popu- 
lation, and affording employment to our labouring classes - are considered, besides the direct pecuniary returns to the Treasury of the Colony, the expense incurred in their establishment in our rivers sinks into insignificance.

In their last Report the Commissioners estimated the cost of each future importation of Ora at $£ 800$, and that estimate has proved strictly correct.

The Commissioners have been informed by the Council of the Victorian Acclimatisation Society that, although entirely concurring in the opinion that another shipment of Ova should be procured, they are unable, in consequence of having no funds at their command, to bear any share in its cost. The Commissioners are, however, persuaded that the Government of that prosperous Colony, which has always shown a deep interest in the enterprise, and given it a generous support, would not, if applied to, refuse their further aid; nor can they doubt that the other adjoining Colonies, and more especially the various provinces of New Zealand, whose rivers are so well suited to become the home of the Salmon and the Trout, would be found ready to assist us.

But, without waiting to learn whether any or all of these Colonies will agree or decline to contribute to the expense of a further prosecution of this great 
enterprise, the Commissioners earnestly hope that Your Excellency's Government will not hesitate to recommend, and that the Parliament will sanction, the appropriation of such a sum as will enable the Commissioners without loss of time to take measures for proceeding with their task.

Since the date of the last Report, various improvements have been made in the ponds at the Plenty; the chief of which has been the construction of two winding rivulets several hundred yards in length, one being connected with the small circular pond in which the Trout are confined, and the other attached to the large pond devoted to the use of the Salmon. To these rivulets both kinds of fish have freely resorted, with undoubted advantage to their health and progress.

The addition of the Salmon Trout to the family under their charge, and the spawning of the Brown Trout, have necessitated the formation of a small additional pond, which is now in progress and will soon be completed.

The Commissioners have also found it advisable to provide for the complete draining off of the water in the large pond when required, by laying down a few iron pipes fitted with a secure valve, which shall effectually prevent the escape of any of the young fish with which it will be again soon peopled. 
The expense involved in these various improvements will be of only trifling amount.

In accordance with the recommendation of the Commissioners contained in their Report of 1864, the Government sanctioned the erection of a cottage for the use of the Superintendent, for which the necessary funds were granted by Parliament.

This building was completed in a very satisfactory manner in the course of last year, and has since been occupied by Mr. Ramsbottom.

The addition of a small room for the use of the Superintendent's assistant, who has lived for several years in a mere tent, has been approved by the Government, and contracted for at a small cost.

The grounds attached to the Ponds having been found of insufficient extent to admit of the increased. accommodation which the well-being of their charge demanded, an additional acre has been obtained on lease from the proprietor for the same period, and on the same terms as those on which the original area is held.

The Commissioners have much pleasure in again bearing testimony to the zeal and intelligence with which their Superintendent, Mr. Ramsbottom, has continued to discharge the important duties of his office.

The Act passed during the last Session of Par- 
liament for the Protection of the Salmon, and the several Proclamations issued by Your Excellency under its authority, have been found to operate in a very beneficial mannex.

The Commissioners believe that few attempts have been made to infringe the provisions of the Law. In some of the bays bordering on the Municipality of Glenorchy some unlawful fishing with the seine is supposed to have taken place; but this violation of the Law has been promptly and energetically suppressed by the Warden and Councillors of the District, aided by their very efficient police, and the active and zealous water bailiff, Mr. Young.

Efficient, however, as the Salmon Act has proved to be, experience has shown to the Commissioners, as was to be anticipated, that it admits of some amendments which it will be their duty to suggest to the Government at an early date, in order that they may be considered, and if approved, enacted during the approaching Session of Parliament.

In conclusion, the Commissioners desire to express their acknowledgment of the constant support which they have on all occasions received from Your Excellency's Government in the performance of the arduous duty entrusted to them.

R. OFFICER,

Chairman of Commissioners. 
Acclimatisation Society's Office,

Melbourne, May 26th, 1866.

Sir,

I have the honour herewith to enclose a copy of a resolution passed by the Council of the Acclimatisation Society for Victoria at the meeting held on the 15th inst.

"The Council of the Acclimatisation Society desires hereby again to record its sense of the important services rendered to Australia by James A. Youl, Esq., and begs to congratulate him upon the large measure of success which has attended the introduction of Salnon and Trout ova by the ship Lincolnshire."

I have the honour to be, Sir, Your most obedient Servant, GEO. SPRIGG,

To James A. Your, Esq.,

Secretary.

Waratah House,

Claphain Park, London.

Acclimatisation Society's Office, 30, Swanston Street,

Sir, Melbourne, July 18, 1868.

I have the honour to inform you that the Council of the Acclimatisation Society of Victoria 
has awarded you a medal in acknowledgment of the eminent services rendered by you to the cause of acclimatisation.

The medal will be handed to you in the course of a few days by Mr. Edward Wilson, and the Council hopes that it will be acceptable to you.

I have the honour to be, Sir, Your most obedient Servant, GEO. SPRIGG.

To J AMES A. YouL, Esq.,

Waratah House,

Clapham Park, London.

Province of Otago, N. Z.,

Superintendent's Ofice,

Dunedin, 1 July, 1868.

SIR,

I do myself the honour to transmit to you. the enclosed resolution, which has been passed by the Provincial Council of Otago. Allow me at the same time, on behalf of the Executive Government of the Province, to express our concurrence in this resolution-to tender to you our grateful acknow. ledgements for the great personal trouble which you took in the shipment of the ova, and to assure you that we are deeply sensible of how much the 
Province owes to your exertions for the success of the experiment.

Instructions have been sent to Mr. Auld, British Agent for the Province, to forward to you a piece of plate with a suitable inscription as a lasting token of the obligation under which the Province of Otago feels itself in this matter.

I have the honour to be, Sir,

Your most obedient Servant,

JAMES MACANDREW,

JaMes Youl, Esq.,

Superintendent.

Waratah House,

Clapham Park, London.

"That the special thanks of this Council are due to James Youl, Esq., for his valuable and disinterested services in connection with the shipment to this Province of the Salmon and Trout Ova recently landed; and that an Address be presented to His Honor the Superintendent, requesting that he may be pleased to place a sum upon the Estimates sufficient to procure a piece of Plate for presentation to Mr. Youl as a lasting tolsen of the obligation under which he has laid this Province.

Passed the Provincial Council, May 20, 1868. WILLIAM H. REYNOLDS, Speaker. CHAS. SMITH, Clerk of Council. 
Inscription on Piece of Plate Presented.

Presented to

Janes ARndell Youl, EsQ.,

By the Superintendent and Provincial Council of the Province of Otagó, New Zealand, in acknowledgment of the very able and valuable services rendered by him on the occasion of the first transmission of Salmon Ova to that Province in January, 1868.

\section{7, Westminster Chambers,}

Victoria Street, Westminster, S. W

$$
\text { Feb. 20, } 1873 .
$$

SIR,

I do myself the honour to thank you, on behalf of the Colony which I represent, for your very strenuous exertions in connection with the recent shipment of Salmon Ova to New Zealand.

I deemed myself especially fortunate in being able to avail myself of your valuable services, which were so generously offered; and the fact that you personally superintended the most important part of the undertaking, namely, the packing and shipping of the Ova, affords the strongest hope that the enterprise will prove a success.

Whether the attempt to stock the New Zealand rivers with Salmon does prove immediately successful or not, I feel sure that both the Govern- 
ment and the Colonists will most fully appreciate the zeal and energy which you have displayed, and will not be slow to acknowledge it.

I have the honour to be, Sir,

Your most obedient Servant,

$$
\text { J. E. FEATHERSTON, }
$$

\section{J AMIES YouL, Esq.,}

Agent-General.

Waratah House, Clapham Park.

Waratah House, Clapham Park,

March 1st, 1873.

$\mathrm{SIR}_{2}$

I have the honour to acknowledge the receipt of your letter of the 20th ult., and I beg leave to express my warmest thanks for the kindly feeling you have expressed on behalf of the Government of New Zealand for my exertions in superintending another shipment of Salmon Ova to that Colony.

Knowing the great expense the Colonists of New Zealand have incurred in the several attempts previously made to introduce the Salmon, I do most sincerely hope that the Oberon will make a quick passage, and that this shipment may prove eminently successful.

I have the honour to be,

Your obedient Servant,

Dr. Featheraton, JAMES A. YOUL. Agent-General for Now Zealand. 
Salmon Ponds, Wallacetown,

Southland, N.Z.

1 May, 1876.

MY DEAR SIR,

I do not think it was ever my lot to take up my pen with so much pleasure as now, for when I wrote by last mail, I had the fear of the old luck haunting me, and although I believed the Ova would turn out well, and the shipment prove a success, I would not allow myself to be too confident after so many disappointments. As the Ova have now nearly all hatched, I may at any rate congratulate you, as the remainder rests with us. I own I did not expect so good a hatching. Your Ova have hatched as truly as if taken from one of our own rivers, scarcely a death at hatching, and, contrary to my expressed belief, are strong good fish; some of those I mentioned as looking too pale in the lower lot of Ova I placed by themselves, and most of them have hatched off good fish. I have not at present seen any deformed fish to signify, as in the Oberon shipment, and the hatching, at any rate, is a perfect success. Of course I can only approximate to the quantity hatched, and can best explain it by saying that my idea on looking over the boxes after all were laid was that I had about 25,000 in all; the next morning I removed 1320 from $\mathrm{Mr}$. Buckland's, and 4.972 from yours, or, in round 
numbers, 6000 in all. Since this I have removed daily the dead ones, numbering 6220 , or say 12000 in all. There are, perhaps, about 1000 still remaining, and most of these should produce fish, and I think I shall not overlay it if I say I have 10,000 hatched; this, if true, I believe represents the largest hatching yet produced at the Antipodes. I do not know what the Norfolk shipment produced, but I think 4000 ; the Lincolnshire I know was said to give 6000 hatched; at least, I had a memo. from the Australasian to that effect, and from about a like quantity-87,000. I am sorry to say $\mathrm{Mr}$. Buckland's lot, though some of them looked so well impregnated, have not hatched off well; so many died just before hatching, and many of them burst. I shall not get more than half of what I anticipated ; most of those which he placed in mid-ice, and taken from the Lancashire rivers proved unimpregnated, and from those six boxes I shall not get 50 fish. It is a great pity those you placed at the bottom of the ship were killed, as most of those not opaque have hatched fish, and it is very strange (but quite carries out my belief) that those boxes which were on top of ice all huddled together have done as well as any, the large boxes had scarcely a dead Ova in them. Unfortunately I sent one of them to Christchurch by the Superintendent's order and one of the lowest tier of your pasking, in all, I 
suppose, about 3000. I see by a press telegram that they have 127 hatched, which, I suppose, represents the hatching. I have heard nothing from those at the Melbourne ice-house, which should do well, as Mr. Clifford thoroughly understands his business, having been several years with the Dunedin Acclimatisation Society, and was with me in Tasmania when we brought over the first suecessful lot of Trout. The rest of the Melbourne shipment, I fear, has met with little success; indeed, I never anticipated anything else, and it is a waste of Ova to send it to a country, the lowest temperature of its winter being $64^{\circ}$; and some 73 of those I tried with Mr. Le Seouf when I was awaiting the Durham. I think they have a good deal to learn there yet about fish hatching, from what $I$ saw and heard. I am, I think, more pleased on your account, if possible, than on my own, as it is so hard after all one's trouble to be sneered at, and all because ships would malre bad passages, over which you could have no control. I always believed it to be only a matter of quick passage, and now people have got over that insane idea that steamers would prove certain death, we shall yet see fifty per cent. hatched, I believe.

You must excuse my writing more by this mail, and as there is another mail in a week, I will advise you in a short note by that if there is any- 
thing fresh to say, and you may always rest assured of my posting you in all the piscicultural news when I have any. And with my best thanks again for all your trouble,

Believe me, dear sir,

Always very truly yours,

H. HOWARD.

J. A. YodL, E'sq.

P.S.-I forgot to say the fish commenced batching, both yours and Mr. Buckland's, on the 22nd; thus were 87 days in ice, and 22 in the hatching boxes at $51^{\circ}$, or 109 days in all.

.7, Westminster Chambers,

London, S.W.

29 January, 1878.

DeAR Sir,

The shipment of Salmon Ova ordered by my Government being now completed, and the Chimborazo having sailed from Plymouth on the 25th instant, it becomes my pleasing duty to express to you, on behalf of the Government of New Zealand my warmest appreciation of, and thanks for, the interest you have taken in this matter, for your successful exertions in procuring the Ova, and for 
the care which you bestowed on the packing, and other arrangements connected with shipping.

I also beg you will convey to the Rev. R. M. Whitaker and Mr. Ramsbottom my thanks for the assistance which they gave in procuring the Ova, as without their cordial co-operation I feel that it would have been very difficult to obtain the Ova.

I remain, dear sir, JULIUS VOGEL, Agent-General for New Zealand.

J AMES YoUL, Esq.

\section{From the "Field."}

SALMON OVA PER CHIMBORAZO.

SIR,

I beg leave to inclose a copy of a letter received this morning from Mr. Howard, of Southland, New Zealand, giving a detailed statement of the result of the shipment of Salmon Ova in January last in the steamship Chimborazo, which I will feel obliged by your having published in the Field for the information of your readers who take an interest in the acclimatisation of the Salmonidæ at the Antipodes.

JAMES A. YOUL.

Waratah House,

Clapham Park, May 14. 
Salmon Ponds, Wallacetown, Southland, N.Z.,

March 26, 1878.

My dear Mr. Youl,

I am sorry I shall not have time to write as full a report of the Salmon Ova as usual. I find the mail goes out to-morrow, and $I$ have a nine miles' walk to post this in time.

The Chimborazo arrived in Melbourne on the 11th of March, and, as the steamer for New Zealand left on the 13th, little time was lost, as I had everything ready for the re-shipment, having left the Ova in the ice until the morning of my leaving Melbourne. We reached the Bluff on the 19th, and the larger half of the Ova were laid by night, by order of the New Zealand Government. I handed two boxes of Mr. Buckland's and one of yours to Sir S. Wilson in Melbourne, and his report appears in a letter published in a Southland paper, which I forward. I fear his anticipations will not be realised. I did not myself examine any of your boxes in Melbourne, but saw two or three of Mr. Buckland's, which were very insecurely fastened, the screws not being long enough; they were nearly all opaque, and until I received Sir Samuel's letter I had little hope of the shipment. On reaching the ponds I tried yours, and was much elated by the first appearance, as all the Ova wero 
bright, with scarcely a dead ovum in any of the boxes. I then examined about twenty from each box with a glass, and regret to say in many of them could not find an impregnated ovum. There were, however, about four boxes in which the Ova are partially fecundated. The fish, although still very backward, are good and healthy. The Ora since then, except in the boxes mentioned (which I put by themselves), have since gradually gone off, as is usual with unimpregnated Ova. This morning I again carefully examined the boxes, and in two lots, containing about four thousand, I can only see one or two fish-the rest of the Ova, when looked at from above, having that unmistakable ring-coloured spot. Of those in the boxes I mentioned as yours, no difficulty remains of ascertaining their condition, as the fish are quite visible to the naked eye. The cause of this want of impregnation is to me a mystery, especially after the late shipments of Ova from America : of two lots containing 100,000 , I could not find a hundred unfecundated, and from one lot 40,000 have been turned in the Outi, and from the other lot 26,000 in tribu. taries of the same stream. The means used in packing are very simple-50,000 in one box, $2 \mathrm{ft}$. square and about $7 \mathrm{in}$. deep. There is first a bright layer of moss, then some thin cotton net, then the Ova, then another cotton net, the moss to lie so on 
for seven layers (and the Ova are at least twice the size of the home fish). This is all enclosed in an outside box about a foot deeper, in which the Ova box is placed and covered with ice, the outside box being double, with about three inches of sawdust between. About a foot of ice is placed on the top, and a thin bag containing sawdust on top of all. I believe these are placed in the ship's ice-house, the different lots being marked for each province, the larger quantities coming here; the success in every case most astonishing. In Nelson they turned out 45,000 from 50,000 Ova. I fear in this case the want of impregnation may have arisen from badness or from late milters, as I see there was great difficulty in obtaining fish at so late a period. Still it seems presumption in me to give an opinion when the shipping was entrusted to a person with the life-long experience of $\mathrm{Mr}$ Ramsbottom.* I hope you will send this to $\mathrm{Mr}$. Buckland, as I have no time to rewrite it, or let him know that most of his Ova were opaque. What are leftperhaps five hundred-are about two-thirds impregnated. His Ova were very small, while those sent by you were large and very beautiful. His moss was also again very sodden-looking; but in neither lot was there any of that mouldy, cobwelby appearance, yours being as fresh as when packed.

* Not the "shipping," but the collection and impregnation.-A.N. 
I may mention, in conclusion, that I received instructions from the Agent-General to take particular notice of the condition of the ice-house, and found at least two feet of ice on all the Ova boxes; and I was assured by several passengers that every care had been used to keep it in good condition.

I hope to have more time by the Suez mail ; but I do not think the Ova will hatch for at least a fortnight, and if I am called upon to give an idea of the quantity, I think I should guess about 1500 to 2000 of yours as good, to about 300 of Mr. Buckland's. The Trout Ova are quite two-thirds good; and I will write my thanks to Mr. Capel next mail. I have no news of the Apanima fish.

Believe me, in haste,

Yours always truly,

H. HOWARD. 
TASMANIA.

\section{SALMON COMMISSIONERS' REPORT} FOR THE YEAR 1876.

Since the date of our last Report very satisfactory evidence of the establishment of the Salmon in the Derwent and its estuary has been accumulated.

During the year 1873 numerous Smolts were captured in various parts of the river; while large bodies of fish of great size were frequently seen in the Derwent through the whole course of its stream, as they had been for the previous six or seven years.

In the month of December of that year the reward of Thirty pounds, which had been offered by the Government for the capture of the first Grilse or Salmon, was claimed by $\mathrm{Mr}$. Joseph Cronly, and paid to him on the recommendation of the Commissioners after the most careful inspection of the fish for which the claim was made, and after it had been subjected to the various anatomical tests 
relied on by the most eminent ichthyologists as a means of distinguishing the different species of Salmonida from each other. This fish was captured in a pool on the mud flat immediately below the Causeway at Bridgewater, in which it had been left by the retirement of the tide, and was one of a shoal that had previously been observed rushing about in the same locality at high water.

During the year 1874 numerous other Grilses were accidentally caught, chiefly in the bays near Hobart Town, in grab-alls or hang-nets set for the capture of native fish. Some of these were minutely compared with the description of the Salmo salar given by Dr. Günther, the greatest living authority on this branch of science, with which they were found to agree.

If any doubt remained respecting the success of the enterprise in which the Colony had so long been engaged, it was dissipated by the capture of a large body of fish in a private seine in Sandy Bay on the night of the 13th January, 1876. This interesting event is thus correctly reported in the Mercury newspaper of date 24th January, 1876 :-

On the night of the 13th January instant six dozen and four Smolts were taken in one haul of a seine net in that part of the estuary of the River Derwent known as Sandy Bay, about a mile below 'Hobart Town. These fish varied in weight from three quarters of a pound to one pound and a 
half; and judging not only from their general appearance, but from the fact that they were taken in water almost, if not quite, as salt as the ocean, it was manifest that they belonged to one of the two migratory species of the genus Salmo which have been introduced to the Colony. After subjecting several of these fish to careful examination, the Salmon Commissioners arrived at the conclusion that they were identical in species with the specimen in the same stage of growth which was caught in December, 1869, and sent to Dr. Günther, of which fish the learned doctor wrote that it presented all the characters by which the true Salmon is distinguishable from its nearest allies.

On the three or four nights following the 13th numerous other specimens were captured both in Sandy Bay and on the opposite shore of the estuary of the Derwent, more than three miles distant, the total number thus destroyed being probably over 200. These fish were sold in Hobart Town, and rapidly rose in price from $3 d$. each on the 15 th to $5 s$. each on the 17th, when attention was drawn to the fact that, under the Salmon Act of Tasmania, the sale of these young fish subjected both seller and purchaser to a heavy penalty, and some check was thus placed on their wanton destruction.

The absolute success of one, if not both, of the migratory species, Salmo salar and Salmo trutta, is, therefore, now certain, and home readers who are in the neighbourhood of salmon rivers will easily appreciate the vast importance to the colony of this result of the experiment.

After this large capture, and up to the present time, numerous Salmon have continued to be caught in the bays, and in the manner above referred to, some of which have been carefully 
inspected and verified by the Commissioners. One of the most recent instances of the capture of a Salmon took place some weeks ago, and is worth recording. A person residing near Risdon Ferry, Mr. Sims, observing a dense shoal of fish close in shore, apparently pursued by a school of porpoises, seized a billet of wood and dashed it amongst them, when one was found to be so disabled as to be easily caught by the hand, and proved to be a true Salmo salar weighing $4 \frac{1}{2}$ lbs. From this incident the abundance of the fish in that locality may be inferred.

Notice having been given in the Government Gazette that the laws enacted for the protection of the Salmon in the Derwent would, in future, be rigidly enforced; the boundary within which all fishing by net had been prohibited was, at the same time, by the Governor's Proclamation, extended lower down the estuary from One Tree Point to Droughty Point.

But the Commissioners believing that, in spite of these measures and of any mere threats of causing the law to be put in force, poaching would still be carried on and extended unless a rigid system of conservation was established, recommended to the Government the appointment of two additional bailiffs for the north and south shores of the estuary of the river. 
With this recommendation the Government has not hitherto seen fit to comply; and the Commissioners have every reason to believe that, in the absence of all effective protection, many Salmon have been destroyed, and the continued stocking of the Derwent so far retarded.

They have no means of discovering to what extent seines have been unlawfully used in the numerous bays below Bridgewater, where it is well known the Salmon abound; but in the immunity from detection and punishment which now exists the facilities for the use of nets over that wide area of the Derwent, together with the high prices which are readily given for any of the three species of the Salmonide that have been introduced into the colony, there can be no doubt that poaching has already been extensively practised, and will be speedily extended unless better means of protection are provided. It is well known to the Commissioners that, in numerous instances, these fish have been sold at the rate of $5 \mathrm{~s}$. a pound, and that a keen competition always exists for them amongst hotel-keepers and others.

The great aim of the Commissioners will now be to procure a supply of ova from the Salmon in the Derwent, for the purpose of their further propagation, and the stocking of the many other streams in the colony which are admirably fitted to be the 
homes of this valuable fish. This task the Commissioners anticipate will be one of considerable difficulty.

The spawning grounds have not yet been discovered, and are probably situated far up the Derwent near its highest sources, according to the habits of Salmon in other parts of the world, where there are few or no inhabitants, and where the river will probably be found full of impediments to the use of a net.

That the fisheries of Tasmania will, at no distant date, become a source of much profit to the Colony, and materially promote its commercial interests, amply repaying all the care and attention that can be bestowed on them, does not admit of a doubt.

The fish in the Derwent, whether Salmon, Salmon Trout, or Common Trout, have not hitherto shown much disposition to take the artificial fly; and it was. therefore an event of some interest when, on 8th October, 1876, the first undoubted Salmon was captured in this manner by $\mathrm{Mr}$. Matthew Seal, one of the Commissioners, below the "Falls" at New Norfolk, although it was only one of a numerous shoal that surrounded the boat from which that gentleman and $\mathrm{Mr}$. Morton Allport were fishing.

The second fish captured by the same means, and weighing $8 \frac{1}{2} \mathrm{lbs}$. fell to Your Excellency's rod and line on the 10th of January following. 
Large trout, reaching a weight of upwards of 16 lbs., have been caught by rod and line from time to time-one of that weight more than three years ago. In some of the tributaries of the Derwent the Trout has afforded good sport, and been so easily caught as to necessitate the closing of several of them for a season in order to prevent their further depopulation.

Many thousand ova and fry of the Trout have continued to be annually produced in the Ponds, and distributed among the rivers of this and some of the neighbouring colonies. Ova and young fish from the Salmon Trout have also been reared, in fewer numbers, from the small supply of the fish of that species which were originally detained in the Ponds or their descendants.

It has been found, however, for the last two seasons that an increasing proportion of the ova of the last named fish have proved infertile.

The cause of this infertility is probably due to the want of that food which is only to be found in the sea, or want of the annual change to salt water ; and, if it should continue, may be remedied by establishing a fresh family of breeding fish by ova brought from the Derwent.

The Commissioners think that they have reason to congratulate the Colony on the signal success of the great experiment of which they have had the 
direction. Although much more protracted than was anticipated, when experience and example were wanting, they now perceive that it has not been more so than the natural laws to which the undertaking has been subject demanded. It has been uniformly successful from the first, and has required only time and care for its full development.

\section{ROBERT OFFICER,}

3rd May, 1877.

Chairman. 
RETURN of the Distribution of Ova and Fry from the Breeding Ponds, River Plenty, during the Years 1873, 1874,1875 , and 1876.

\section{OVA.}

Salmon Trout.

1873. 1874, 1875. 1876.

Iaunceston $300 \quad 500$

New Zealand $300 \quad \ldots \quad \ldots \quad 250$

Victoria 200 250

Brown Trout.

Victoria $2300 \quad 3550 \quad 3000 \quad 2000$

Launceston $7500 \quad 6300$

New Zealand $600 \quad 800$

Now South Wales $250 \quad 250$

North East Coast Rivers

Hobart Town. 100

Western Australia.

100

... 800

FRY.

Salmon Trout.

Sonth Esk River $\begin{array}{rrrr}\cdots & \cdots & \cdots & 200 \\ \cdots & \cdots & 200 & \cdots\end{array}$

River Plenty

Brown Trout.

River Plenty $\begin{array}{llll}\ldots & 200 & 100 & 750\end{array}$

River Derwent ... $\quad \ldots \quad 950 \quad \ldots$

East Coast Rivers. ... $\quad$... 620

River Styx $\begin{array}{llll}\ldots & \ldots & \ldots & 400\end{array}$

Hobart Town. 1200

Launceston ...

Blackman River

River Forth and Tributaries

$\begin{array}{llll}\ldots & \ldots & \ldots & 300\end{array}$

$\begin{array}{llll}\ldots & \ldots & \ldots & 500\end{array}$ 


\section{TASMANIA.}

\section{SALMON COMMISSIONERS.} REPORT FOR 1878.

The Salmon Commissioners have the pleasure of reporting that the different species of Salmonidce in the various rivers in which they have become acclimatised continue to increase in a most satisfactory manner.

During the last four years, towards the end of September or early in October, Salmon smolts have been captured in a water-race leading to the Ponds from the River Plenty, evidently on their way to the Derwent. The fish were beautifully bright and well formed, and specimens have each year been placed in the Museum for public inspection. The Commissioners consider the presence of these smolts in the Plenty conclusive evidence that the parent fish go up that river to deposit their ova; and as many thousands of ova are annually taken from the Plenty for the purpose of distribation throughout the Colony and for sale to other Colonies, it is now more than probable that, in 
addition to the Brown Trout, both the Salmon and Salmon Trout have become well established in many and widely separate localities in this Colony, and in the neighbouring continent.*

Throughout the late fishing season the waters of the Upper Derwent and the Plenty were literally swarming with Salmonide, many of which were captured for the purpose of selecting good specimens for the Sydney Exhibition; the largest fish taken on these occasions being a Brown Trout weighing sixteen pounds. As to this fish it now appears to be an established fact that it attains to a larger average size here than in English waters, very many having been captured weighing from ten to twenty pounds.

In February, 1878, a fine fish weighing six pounds was caught about two miles below Hobart Town, and presented so many characteristics of the true Salmon that the head was transmitted to Professor $M^{\circ}$ Coy for examination. The following is the reply of the learned Professor-

I have just received the head of the fish caught on Friday, 8th of February, 1878, in the Derwent, Tasmania, in net, and have the pleasure of informing you that it is a well-marked true Salmon (Salmo salar).

* There is not a shadow of proof that any migratory species of Salmo has yet become established on the continent of Australia.-A. N. 
As some doubts-in spite of all evidence to the contrary-are occasionally expressed as to the acclimatisation of the Salmo salar, the above decided opinion by such an authority as Professor $\mathrm{M}^{\circ} \mathrm{Coy}$ must command general satisfaction, and go far to extinguish any scepticism which may still exigt.

We may add that a finer specimen of Salmon than that reported upon by Professor $M^{\circ}$ Coy has recently been captured (by the rod) near New Norfolls, and forwarded to the International Exhibition at Sydney.

The Commissioners regret that it is their painful duty to record the death of three of the oldest of their number-Mr. Allport, Captain Langdon, and the Hon. Sir Robert Officer.

By the death of Mr. Allport the Commission has sustained a most serious loss. His varied knowledge of Natural History, his great practical experience in Pisciculture, and the untiring energy, zeal, and ability with which, from its very inception, he addressed himself to the great, and then novel, experiment of introducing fish by means of their ova from Europe, are too well known to require comment.

Captain Langdon at a former period of his life proved himself, on many occasions, to be an active and practical supporter of the cause of acclimatisation. 
The Honourable Sir Robert Officer was Chairman of the Commission from its first appointment. His enthusiasm in the cause of the Salmon experiment was proverbial, and much of its success (of which he was satisfied long before belief in it became so general as at present) was due to his vigilance and unceasing supervision.

The good effect of the closure of the river was proved recently in an attempt which was made under our authority to secure specimens of Salmon, and which resulted in the capture of an enormous and extraordinary quantity of indigenous fish.

Proof was thus afforded that the closed portion of the river has become a nursery, not only for the Salmonide but for our native fish. The fishermen are thus in a better position than if the river was open, as vast numbers of the fish are certain to push out of the protected waters and thus keep up a good and permanent supply for the market.

We venture to assert, if the rirer were now thrown open the result would be most disastrous: in the course of a few years the fish would again become as scarce as ever, and the fisherman would have to go much farther afield to practise his calling under far greater difficulties than at present.

ROB. CAR READ,

8th Seltember, 1879.

Chairman. 
RETURN of the Distribution of Ova and Fry from the Breeding Ponds, River Plenty, during the Year 1878.

$$
\text { OVA. }
$$

Brown Trout.

New South Wales....................................... 500

Victoria .................................................... 8000

Streams in the vicinity of Lake St. Clair, Tasmania 2000

FRY.

\section{Brown Trout.}

River Mersey.......................................... 500

River Plenty ........................................... 1500

Ben Lomond Rivolet ................................. $\quad 300$

Macquarie River ...................................... $\quad 500$

Meandex River ........................................ 500

Launceston .......................................... 1000

Coal River ......................................... 1950

Lisdillon ............................................... 900

Huon ................................................. $\quad 250$

Prossers .............................................. 450

Since their last Report your Commissioners have continued to receive evidence of the rapid increase of the various species of Salmonide in the Rivers of the Colony.

It may be interesting to record the fact that, for the first time in the River Derwent, fishing for Salmon with rod and line has been successfully practised in the salt water between Bridgewater and Austin's Ferry. 
Great numbers of migratory species have been captured by means of grab-all nets in the estuary of the Derwent, one of which was estimated by its captor to have weighed at least $10 \mathrm{lbs}$. It is unfortunate that this specimen was not preserved for examination, as its capture was effected below Droughty Point, almost at the entrance of the river; and as no pronounced specimen of Salmo salar of that weight had previously been caught, it would have been very satisfactory to have known the true character of the fish in question.

In October, as in former years, Smolts again made their appearance in the River Plenty on their way to sea; but in consequence of the diversion of the river by flood, the numbers which entered the shoots leading to the Ponds were less than on former occasions. Your Commissioners have caused some of these fish to be retained in a special pond, in the hope that they will deposit Ova, and thus enable their progeny to be placed in other rivers of the Colony. Should the experiment prove successful there will be no difficulty in rapidly stocking other rivers with migratory salmonids.

It has been observed when captured migratory species are introduced into our breeding ponds and permanently retained there, that at first, during the migratory season, they make considerable 
effort to escape from their confinement. It has also been noticed that although they continue to present a healthy outward appearance, yet if the forced imprisonment is prolonged the generative organs are seriously affected, for they invariably become perfectly sterile. These observations may be of much interest to ichthyologists and to others interested in the natural history of introduced fishes.

During the year 1880, 23,000 Ova were supplied to the other Colonies, and 2350 Fry were distributed in various rivers of this Colony. The Commissioners are always prepared to supply the requirements of any locality upon application being made to them.

Your Commissioners are aware that poachers are still very numerous; but the number of licensed rod fishermen having increased from 138 in season 1876-77 to 382 in the season just closed, is a satisfactory proof that the offenders are not now so numerous as formerly.

ROB. CAR READ,

Chairnan.

30th June, 1881. 
RETURN of the Distribution of Ova and Fry from the Breeding Ponds, Fiver Plenty, during the Year 1880.

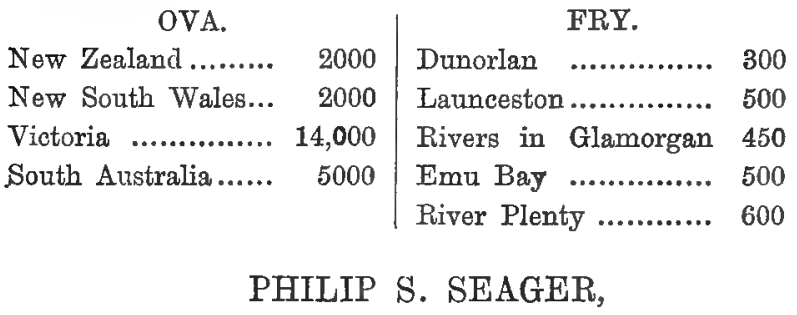

Secretary to the Commission. 
SHIPMENTS OF

SALMON, SALMON TROUT, AND BROWN TROUT OVA MADE BY

MR. JAMES A. YOUL.

TO THE ANTIPODES.

1.-February, 1860. By Sarah Curling, from Liverpool to Melbourne............Salmon ova 25,000

2.-March 4, 1862. By Beautiful Star, from London to Hobart Town ............... Salmon ova 80,000

3.-January 21, 1864. By Norfolle, from London to Melbourne and Tasmania......Salmon ova 118,000 Present from Admiral Keppel, through Mr. Frank Buckland ...............Brown trout ova $\quad 1,200$ Present from Mr. Francis Francis,

Brown trout ova $\quad 1,500$

4.-January 20, 1866. By Lincolnshire, from London to Melbourne and Tasmania, Salmon ova 93,000 Salmon-trout ova $\quad 15,000$ Brown trout ova $\quad 500$

5.-January, 1868. By Celestial Queen, from Lon. don to Otago, New Zealand .......Salmon ova 120,000 Salmon-trout ova 4,000

From Bavaria Salma umbla ova 9,000

Present from Lord Essex, through Mr. Frank Buckland ......................Brook-trout ova 6.-January, 1869. By Mindora, from London to Otago, New Zealand ...............Salmon ova Taken by Mr. Frank Buckland, Salmon-trout ova 
7.-January, 1873. By Oberon, from London to Otago, New Zealand ...............Salmon ova 120,000

8.-January, 1876. By S.S. Durham, from London to Melbourne and New Zealand, joint shipment.

Mr. J. A. Youl

Salmon ova

Mr. Frank Buckland Salmon ova 90,000 85,000

9.-January, 1878. By S.S. Chimborazo, from London to New Zealand, joint shipment. Mr. J. A. Youl.........................Salmon ova Mr. Frank Buckland ................. Salmon ova 24,000 20,000 10.-January, 1879. By P.\& O. S.S. and Orient line S.S. Cuzco, five boxes brook-trout, about 5,000 


A Catalogue of American and Foreign Books Published or Imported by MessRs. SAMPSON Low \& Co. can be had on application.

Crown Buildings, 188, Fleet Street, London, December, r88r.

\title{
A Belertion from the 垔ist of Books
}

\author{
PUBLISHED BY
}

\section{SAMPSON LOW, MARSTON, SEARLE, \& RIVINGTON.}

\section{ALPHABETICAL LIST.}

A CLASSIFIED Educational Catalogue of Works published in Great Britain. Demy Svo, cloth extra. Second Edition, revised and corrected, 5 .

About Some Fellows. By an Eton Bov, Author of "A Day of my Life." Cloth limp, square r6mo, 2s. $6 u$.

Adventures of a Young Naturalist. By LuCien Biart, with II7 beautiful Illustrations on Wood. Edited and adapted by PARKER GILlMORE. Post 8vo, cloth extra, gilt edges, New Edition, 7s. $6 d$. Afghan Knife (The). A Novel. By Robert Armitage STERnDale, Author of "Seonee." Small post 8vo, cloth extra, 6s. Alcott (Louisa M.) Jimmy's Cruise in the "Pinafore." With 9 Illustrations. Second Edition. Small post 8vo, cloth gilt, 3s. 6d.

- - Aunt Jo's Scrap-Bag. Square 16mo, 2s. 6d. (Rose Library, is.)

Little Men : Life at Plumfeld with Jo's Boys. Small post $8 v$ o, cloth, gilt edges, $3 s .6 d$. (Rose Library, Double vol. 2s.) Little Women. I vol., cloth, gilt edges, $3^{s .} 6 d$. (Rose Library, 2 vols., Is. each.)

- Old-Fashioned Girl. Best Edition, small post 8vo, cloth extra, gilt edges, $3 s .6 d$. (Rose Library, 2s.)

- Work and Beginning Again. A Story of Experience. (Rose Library, 2 vols., Is. each.)

Shawl Straps. Small post 8vo, cloth extra, gilt, 3s. 6d. Eight Cousins; or, the Aunt Hill. Small post 8vo, with Illustrations, 3 s. $6 d^{\text {. }}$. 3s. $6 d$.

The Rose in Bloom. Small post 8vo, cloth extra, Under the Lilacs. Small post 8vo, cloth extra, 5s. 
Alcott (Louisa M.) Fack and Fill. Small post 8vo, cloth extra, $5^{5 .}$

"Miss Alcott's stonies are thoroughly healthy, full of racy fun and humour .. exceedingly entertaining . . . We can recommend the "Eight Cousins. " A thenewrit.

Aldrich (T. B.) Friar Jerome's Beautiful,Book, E.c. Selected from "Cloth of Gold," and "Flower and Thorn." 18mo, very choicely printed on hand-made paper, parchment cover, 3s. $6 d$.

Alpine Ascents and Adventures; or, Rock and Snow Sketches.

By H. Scrütz Wilson, of the Alpine Club. With Illustrations by

Whymper and Marcus Stone. Crown 8vo, ros. 6d. and Edition. Andersen (Hans Christian) Fairy Tales. With Illustrations in Colours by E. V. B. Cheap Edition, in the press.

Angling Literature in England; and Descriptions of Fishing by the Ancients. By O. LAMBERT. With a Notice of some Books on other Piscatorial Subjects. Fcap. 8vo, vellum, top gilt limp, 35. $6 d$.

Architecture (The Twenty Styles of). By Dr. W. Wood, Editor of "The Hundred Greatest Men." Imperial 8vo, with 52 Plates.

Art Education. See "Illustrated Text Books," "Illustrated Dictionary," "Biographies of Great Artists."

Autobiography of Sir G. Gilbert Scott, R.A., F.S.A., S.c. Edited by his Son, G. Gilbert ScorT. With an Introduction by the DeAN OF ChICHeSTer, and a Funeral Sermon, preached in Westminster Abbey, by the DEAN of Westminster. Also, Portrait on steel from the portrait of the Author by G. RICHMOND, R.A. I vol., demy $8 \mathrm{vo}$, cloth extra, I8s.

Autumnal Leaves. By F. G. Heath. Illustrated by 12 Plates, comprising 252 figures of Autumn Leaves and Leaflets, exquisitely coloured after Nature; 4 Page and 14 Vignette Drawings, by FRED. G. SHORT, of New Forest Scenery, and 12 Initial-letter Leaf Designs by the Author. Cloth, imperial 16mo, gilt edges, with special Cover showing Autumn Leaves printed in colours, price 14s.

\section{THE BAYARD SERIES.}

\section{Edited by the late J. HaIN Faiswel.}

Comprising Pleasure Books of Literature produced in the Choicest Style as Companionable Volumes at Home and Abroad.

"We can hardly imagine better books for boys to read or for men to ponder over." Times.

Price 2s. 6a. each Volum, complete in itself, flexible clath extra, gilt edges, with silk Headbards and Registers.

The Story of the Chevalier Bayard. (The Essays of Abraham Cowley, in. By M. De Berville.

De Joinville's St. Louis, King of Abdallah; or, The Four Leaves, France. By Edouard Laboullaye. 
The Bayard Series (continued) :-

Table-Talk and Opinions of Na- Imaginative Poems. With Preface poleon Buonaparte.

Vathek: An Oriental Romance. By William Beckford.

The King and the Commons. A Selection of Cavalier and Puritan Songs. Edited by Professor Morley.

Words of Wellington : Maxims and Opinions of the Great Duke.

Dr. Johnson's Rasselas, Prince of Abyssinia. With Notes.

Hazlitt's Round Table. With Biographical Introduction.

The Religio Medici, Hydriotaphia, and the Letter to a Friend. By Sir Thomas Browne, Knt.

Ballad Poetry of the Affections. By Robert Buchanan.

Coleridge's Christabel, and other Prince Albert's Golden Precepts. A Case containing 12 Volumes, frice 3rs. 6d.; or the Case separately, price 3 s. 6 d.

Beauty and the Beast. An Old Tale retold, with Pictures by E. V. B. 4to, cloth extra. ro Illustrations in Colours. I2s. $6 d$. Begum's Fortune (The): A New Story. By Jules Verne. Translated by W. H. G. KINGSTON. Numerous Illustrations. Crown 8vo, cloth, gilt edges, $7 s .6 d$; plainer binding, plain edges, $5 s$. Ben Hur: A Tale of the Christ. By L. Wallace. Crown $8 \mathrm{vo}, 6 s$.

Beumers' German Copybooks. In six gradations at $4 d$. each. Bickersteth's Hymnal Companion to Book of Common Prayer may be had in various styles and bindings from $\mathrm{I} d$, to $21 \mathrm{~s}$. Price List and Prospectus will be forwarded on application.

Bickersteth (Rev. E. H., M.A.) The Reef, and other Parables. I vol., square $8 \mathrm{vo}$, with numerous very beautiful Engravings, 2s. $6 d$.

- The Clergyman in his Home. Small post 8vo, 1 s. The Master's Home-Call; or, Brief Memorials of Alice Frances Bickersteth. 20th Thousand. 32mo, cloth gilt, Is.

The Master's Will. A Funeral Sermon preached on the Death of Mrs. S. Gurney Buxton. Sewn, 6d.; cloth gilt, Is. The Shadow of the Rock. A Selection of Religious

Poetry. I8mo, cloth extra, 2s. 6 .

The Shadowed Home and the Light Beyond. $7^{\text {th }}$

Edition, crown 8vo, cloth extra, 5 s. 
Biographies of the Great Artists (Illustrated). Each of the following Volumes is illustrated with from twelve to twenty full-page Engravings, printed in the best manner, and bound in ornamental cloth cover, $3 s .6 d$. Library Edition, bound in a superior style, and handsomely ornamented, with gilt top; six Volumes, enclosed in a cloth case, with lid, f, I IIs, 6d, each case.

\begin{tabular}{|c|c|c|}
\hline $\begin{array}{l}\text { Hogarth. } \\
\text { Turner. } \\
\text { Rubens. } \\
\text { Holbein. } \\
\text { Tintoretto. } \\
\text { Little Masters of } \\
\text { Germany. } \\
\text { Fra Angelico and } \\
\text { Masaccio. } \\
\text { Fra Bartolommeo. }\end{array}$ & $\begin{array}{l}\text { Giotto. } \\
\text { Raphael. } \\
\text { Van Dyck and Hals. } \\
\text { Titian. } \\
\text { Rembrandt. } \\
\text { Leonardo da Vinci. } \\
\text { Gainsborough and } \\
\text { Constable. } \\
\text { Sir David Wilkie. } \\
\text { Van Eyck. }\end{array}$ & $\begin{array}{l}\text { Figure Painters of } \\
\text { Holland. } \\
\text { Michel Angelo. } \\
\text { Delaroche and Vernet. } \\
\text { Landseer. } \\
\text { Reynolds. } \\
\text { Velasquen } \\
\text { Mantegna and } \\
\text { Francia. } \\
\text { Albert Durer. }\end{array}$ \\
\hline $\begin{array}{l}\text { Claude Lorraine. } \\
\text { Correggio. } \\
\text { Watteau, Lannet, } \\
\text { and Boucher. }\end{array}$ & $\begin{array}{l}\text { Price } 2 s .6 d . \text { each. } \\
\text { Sir Thos, Lawrence. } \\
\text { Rousseau \& Millet. } \\
\text { Meissonier. } \\
\text { Overbeck. }\end{array}$ & $\begin{array}{l}\text { Murillo. } \\
\text { Early Italian Sculp- } \\
\text { tors. }\end{array}$ \\
\hline
\end{tabular}

Birthday Book. Extracts from the Writings of Theodore Emerson. Square I6mo, cloth extra, numerous Illustrations, very choice binding, 3 s. $6 d$.

Birthday Book. Extracts from the Poems of Whittier. Square $16 \mathrm{mo}$, with numerous Illustrations and handsome binding, $35.6 d$.

Black ( $W m$.) Three Feathers. Small post 8vo, cloth extra, 6s. Lady Silverdale's Szeetheart, and other Stories. I vol., small post $8 \mathrm{vo}, 6 \mathrm{~s}$.

Kilmeny: a Novel. Small post 8vo, cloth, 6s. In Silk Attire. 3 rd Edition, small post 8vo, 6s.

- A Daughter of Heth. I I th Edition, small post 8vo, 6s. - Sunrise. Small post $8 \mathrm{vo}, 6 \mathrm{~s}$.

Blackmore $(R . D$.$) Lorma Doone. roth Edition, cr. 8vo, 6s.$ - Alice Lorraine. I vol., small post 8vo, 6th Edition, 6s. Clara Vaughan. Revised Edition, 6s. - Cradock Nowell. New Edition, 6s.

- Cripps the Carrier. 3 rd Edition, small post 8vo, 6s. Mary Anerley. New Fdition, 6s. Erema; or, My Father's Sin. With I 2 Illustrations. small post $8 \mathrm{vo}, 6 s$. 
Blossoms from the King's Garden: Sermons for Children. By the Rev. C. Bosanquet. 2nd Edition, small post 8vo, cloth extra, 6s. Blue Banner. (The); or, The Adventures of a Mussulman, a Christian, and a Pagan, in the time of the Crusades and Mongol Conquest. Translated from the French of LEON CAHUN. With Seventy-six Wood Engravings. Imperial I6mo, cloth, gilt edges, 7s. $6 d$. ; plainer binding, 5 s.

Bock (Carl). The Head Hunters of Borneo: Up the Mahakkam, and Down the Barita; also Journeyings in Sumatra. I vol., super-royal 8vo, 32 Coloured Plates, cloth extra, $36 s$.

Book of the Play. By DutTon Cook. New and Revised Edition. I vol., cloth extra, 7s. $6 d$.

Boy's Froissart (The). 7s. 6d. See "Froissart."

Bay's King Arthur (The). With very fine Illustrations.

Square crown 8vo, cloth extra, gilt edges, $7 s .6 d$. Edited by SIDNEY

LANIER, Editor of "The Boy's Froissart."

Boy's Mabinogion (The): being the Original Welsh Legends of King Arthur. Edited for Boys, with an Intrbduction by SIDNEY LANIER. With numerous very graphic Illustrations. Crown 8vo, cloth, gilt edges, $7 s .6 d$.

Breton Folk: An Artistic. Tour in Brittany. By Henrì BLAĆKBURN, Author of "Artists and Arabs," "Normandy Picturesque," \&c. With 17I Illustrations by RANDoLPH CALDECOTT, Imperial 8vo, cloth extra, gilt edges, $2 \mathrm{Is}$.

British Goblins : Welsh Folk-Lore, Fairy Mythology, Legends, and Traditions. By WIRT SIKes, United States Consul for Wales, Author of "Rambles and Studies in Old South Wales." Second Edition. 8vo, I8s.

Burnaby (Capt.). See "On Horseback."

Burnham Beeches (Heath, F. G.). With numerous Illustrations and a Map. Crown 8vo, cloth, gilt edges, 3s. $6 d$ Second Edition.

"A pretty description of the Beeches." - Daily News.

"A charming little volume."-Globe.

Burroughs (John). Pepacton: A Summer Voyage, and other Essays. Small post 8vo, cloth, 7 s. $6 d$.

Butler (W. F.) The Great Lone Land; an Account of the Red River Expedition, I869-70. With Illustrations and Map. Fifth and Cheaper Edition, crown 8vo, cloth extra, 7 s. $6 d$.

- The Wild North Land; the Story of a Winter Journey with Dogs across Northern North America. Demy 8vo, cloth, with

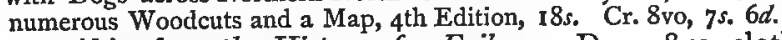
and Adition, 160 : the History of a Failure, in crown 8vo, $7 s .6 \%$ - Red Cloud. Crown 8vo, gilt edges, $75.6 d$. [In the press.

CADOGAN (Lady A.) Illustrated Games of Patience. Twenty-four Diagrams in Colours, with Descriptive Text. Foolsap 4to, cloth extra, gilt edges, 3rd Edition, I2s. $6 d$. 
Cambridge Trifles; or, Splutterings from an Undergraduate Pen. By the Author of "A Day of my Life at Eton," \&c. 16mo, cloth extra, 2s. $6 d$.

Changed Cross (The), and other Religious Poems. I6mo, 2s. $6 \mathrm{~d}$. Child of the Cavern (The); or, Strange Doings Underground. By Jules Verne. Translated by W. H. G. Kingston. Numerous Illustrations. Sq. cr. 8vo, gilt edges, $7 s .6 d$. ; cl., plain edges, 5 s.

Child's Play, with 16 Coloured Drawings by E. V. B. Printed on thick paper, with tints, 7 s. $6 d$.

Nere. By E. V. B. Similar to the above. See New.
- A New and Cheap Edition of the two above, con

taining 48 Illustrations by E. V. B., printed in tint, handsomely bound, 3 s. $6 d$.

Choice Editions of Choice Books. 2s. 6d. each, Illustrated by C. W. Cope, R.A., T. CReswick, R.A., E. DunCan, BIrKeT Foster, J. C. Horsley, A.R.A., G. Hicks, R. RedGrave, R.A., C. Stonehouse, F. Tayler, G. Thomas, H. J. Townshend, E. H. WEHNERT, HARRISON WEIR, \&c.

Bloomfield's Farmer's Boy. Milton's L'Allegro.

Campbell's Pleasures of Hope. Poetry of Nature. Harrison Weir.

Coleridge's Ancient Mariner. Rogers' (Sam.) Pleasures of Memory.

Goldsmith's Deserted Village. Shakespeare's Songs and Sonnets.

Goldsmith's Vicar of Wakefield. Tennyson's May Queen.

Gray's Elegy in a Churchyard. Elizabethan Poets.

Keat's Eve of St. Agnes. Wordsworth's Pastoral Poems.

"Such works are a glorious beatification for a poet." -A Athenerum.

Christ in Song. By Dr. Philip Schaff. A New Edition, Revised, cloth, gilt edges, $6 s$.

Confessions of a Frivolous Girl (The): A Novel of Fashionable

Jife. Edited by Robert Grant. Crown 8vo, 6 s.

Cornet of Horse (The) : A Story for Boys. By G. A. Henty.

Crown 8vo, cloth extra, gilt edges, numerous graphic Illustrations, 5 s.

Cripps the Carrier. 3 rd Edition, 6s. See Blackmore.

Cruise of H.M.S. "Challenger" (The). By W.J. J. Spry, R.N. With Route Map and many Illustrations. 6th Edition, demy 8vo, cloth,

18s. Cheap Edition, crown 8vo, some of the Illustrations, 7s. $6 d$.

Cruise of the Walnut Shell (The). An instructive and amusing Story, told in Rhyme, for Children. With 32 Coloured Plates.

Square fancy boards, 5 s.

Curious Adventures of a Field Cricket. By Dr. ERnest CANDizze. Translated by N. D'AnVERs. With numerous fine Illustrations. Crown 8vo, gilt, 7s. 6d.; plain binding and edges, 5 s.

\section{$D^{A N A}(R . H$.$) Two Years before the Mast and Twenty-Four$ years After. Revised Edition, with Notes, I2mo, $6 s$. Daughter $(A)$ of Heth. By W. BLACK. Crown 8vo, 6s.}


Day of My Life $(A)$; or, Every Day Experiences at Eton. By an EтоN Boy, Author of "About Some Fellows." 16mo, cloth extra, 2s. 6d. 6th Thousand.

Diane. By Mrs. Macquoid. Crown 8vo, 6s.

Dick Cheveley: his Fortunes and Misfortunes. By W. H. G. KInGSTON. $350 \mathrm{pp}$., square $16 \mathrm{mo}$, and 22 full-page Illustrations. Cloth, gilt edges, $7 s .6 d$; plainer binding, plain edges, $5 s$.

Dick Sands, the Boy Captain. By Jules Verne. With nearly 100 Illustrations, cloth, gilt, ros.6d.; plain binding and plain edges, 5 s.

$E^{I G H T}$ Cousins. See Alcotr.

Elementary History (An) of Art. Comprising Architecture, Sculpture, Painting, and the Applied. 'Arts. By N. D'Anvers, Author of "Science Ladders." With a Preface by Professor ROGEle SMITH. New Edition, illustrated with upwards of 200 Wood Engravings. Crown 8vo, strongly bound in cloth, price 8s. 6d.

Elementary History $(A n)$ of Music. Edited by OwEN J.

Dullea. Including Music among the Ancient Nations; Music in the Middie Ages; Music in Italy in the Sixteenth, Seventeenth, and Eighteenth Centuries; Music in Germany, France, and England. Illustrated with Portraits of the most eminent Composers, and Engravings of the Musical Instruments of many Nations. Crown 8vo, handsomely bound in cloth, price $35.6 d$.

Elinor Dryden. By Mrs. Macquold. Crown 8vo, 6s. Embroidery (Handbook of). By L. HIGGIN. Edited by LADY MARIAN AlFord, and published by authority of the Royal School of Art Needlework. With 16 page Illustrations, Designs for Borders, \&c. Crown 8vo, 5 s.

Enchividion of Epictetus; and the Golden Verses of Pythagoras.

Translated into English, Prose and Verse; with Notes and Scriptural References, together with some original Poems. By the Hon. THos.

TALBOT. Crown 8vo, cloth, 5. .

English Philosophers. Edited by Iwan Muller, M.A., New College, Oxon. A Series of Volumes containing short biographies of the most celebrated English Philosophers, to each of whom is assigned a separate volume, giving as comprehensive and detailed a statement of his views and contributions to Philosophy as possible, explanatory ratherthan critical, opening with a brief biographical sketch, and concluding with a short general summary, and a bibliographical appendix. Each Volume contains about 200 pp. Sq. $16 \mathrm{mo}$, 3s.6d. each. Bacon. Professor FowLER, Professor of Logic in Oxford.

Berkeley. Prof.T.H. GreEN, Professor of Moral Philosophy, Oxford. Hamilton. Professor MoNk, Professor of Moral Philosophy, Dublin. J. s. Irill. HELEN TAYLOR, Editor of "The Works of Buckle," \&c. IIansel. Rev. J. H. HuCkin, D.D., Head Master of Repton. Adam Smith. J. A. FARRER, M.A., Author of "Primitive Manners and Customs." 
English Philosophers (continued) :-

Hobbes. A. H. GosseT, B.A., Fellow of New College, Oxford.

Bentham. G. E. BuckLE, M.A., Fellow of All Souls', Oxford.

Austin. Harry Johnson, B.A., late Scholar of Queen's College, Oxford.

Hartley. $\}$ E. S. Bowen, B.A., late Scholar of New College,

James Mrill. $\}$ Oxford.

Shaftesbury.
Hutcheson. Professor Fowler.

Arrangements are in progress for volumes on LOCKE, HUMB, PALBY, REID, \&oc.

Episodes of French History. Edited, with Notes, Genealogical,

IIistorical, and other Tables, by Gustave Masson, B.A.

I. Charlemagne and the Carlovingians.

2. Louis XI. and the Crusades.

3. Part I. Francis I. and Charles V.

, II. Francis I. and the Renaissance.

4. Henry IV, and the End of the Wars of Religion.

The above Series is based upon M. Guizot's "History of France."

Each volume choicely Illustrated, with Maps, 2s. $6 d$.

Erema; or, My Father's Sin. See Blackmore.

Etcher (The). Containing 36 Examples of the Original

Etched-work of Celebrated Artists, amongst others: BIRKET FOSTER,

J. E. Hodgson, R.A., Colin Hunter, J. P. Heseltink, Robert

W. MACBETH, $R$. S. CHATTOCK, \&c. Vol. for 188I, imperial 4to,

cloth extra, gilt edges, $2 l$. 12s. 6d. Monthly, $3 s .6 d$.

Eton. See "Day of my Life," "Out of School," "About Some Fellows."

FARM Ballads. By Will Carleton. Boards, is. ; cloth, gilt edges, Is. $6 d$.

Farm Festivals. By the same Author. Uniform with above. Farm Legends. By the same Author. See above. Felkin (R. W.) and Wilson (Rev. C. T.) Uganda and the

Egyptian Soudan. An Account of Travel in Eastern and Equatorial Africa ; including a Residence of Two Years at the Court of King Mtesa, and a Description of the Slave Districts of Bahr-el-Ghazel and Darfour. With a New Map of 1200 miles in these Provinces; numerous Illustrations, and Anthropological, Meteorological, and Geographical Notes. By R. W. FrLRIN, F.R.G.S., Member of the Anthropological Institute, \&c., \&c. ; and the Rev. C. T. WIISON, M.A. Oxon., F.R.G.S., Member of the Society of Arts, Hon. Fellow of the Cairo Geographical Society. 2 vols., crown 8vo, cloth, $28 \mathrm{~s}$.

Fern Paradise (The): A Plea for the Culture of Ferns. By F. G. HeATH. New Edition, entirely Rewritten, Illustrated by Eighteen full-page, and numerous other Woodcuts, including 8 Plates of Ferns and Four Photographs, large post 8vo, cloth, gilt edges, 12s. 6\%. Sixth Edition.

"All lovers of ferns will be delighted with the illustrated edicion of Mr. Heath's "Fern Paradise."-Saturday Revicu. 
Fern World (The). By F. G. HeAth. Illustrated by Twelve Coloured Plates, giving complete Figures (Sixty-four in all) of every Species of Britisl Fern, printed from Nature; by several full-page and other Engravings. Cloth, gilt edges, 6th Edition, 12s. 6d.

Few $(A)$ Hints on Proving Wills. Enlarged Edition, 1 s.

First Steps in Conversational French Grammar. By F. Jui.ıEv. Being an Introduction to "Petites Leçons de Conversation et de Grammaire," by the same Author. Fcap. $8 v 0,128$ pp., Is.

Four Lectures on Electric Induction. Delivered at the Royal Institution, 1878-9. By J. E. H. Gordon, B.A. Cantab. With numerous Illustrations. Cloth limp, square $16 \mathrm{mo}, 3$.

Foreign Countries and the British Colonies. Edited by F.S. Puliring, M.A., Lecturer at Queen's College, Oxford, and formerly Professor at the Yorkshire College, Leeds. A Series of small Volumes descriptive of the principal Countries of the World by well-known Authors, each Country being treated of by a Writer who from Personal Knowledge is qualified to speak with authority on the Subject. The Volumes average 180 crown 8vo pages each, contain 2 Maps and Illustrations, crown 8vo, $3 s .6 d$.

\section{The following is a List of the Volumes:-}

Denmark and Iceland. By E. C. OrTte, Author of "Scandinavian History," \&c.

Greece. By L. Sergeant, B.A., Knight of the Hellenic Order of the Saviour, Author of "New Greece."

Switzerland. By W. A. P. CoolIDGE, M.A., Fellow of Magdalen College, Editor of The Alpine Fournal.

Austria. By D. KAY, F.R.G.S.

Russia. By W. R. MorFILL, M.A., Oriel College, Oxiord, Lecturer on the Ilchester Foundation, \& $c$.

Persia. By Major-Gen. Sir F. J. GoLDSMID, K.C.S.I., Author of "Telegraph and Travel," \&c.

Japan. By S. Mossman, Author of "New Japan," \&c.

Peru. By Clements H. Markham, M.A., C.B.

Canada. By W. Fraser RAE, Author of "Westward by Rail," "From Newfoundland to Manitoba," \&c.

Sweden and Norway. By the Rev. F. H. Woods, M.A., Fellow of St. John's College, Oxford.

The West Indies. By C. H. EDEN, F.R.G.S., Author of "Frozen Asia," \&c.

New Zealand.

France. By M. RoberTs, Author of "The Atelier du Lys,"\&c.

Egypt. By S. LANE POOLE, B.A., Author of "Life of E. Lane," \&c.

Spain. By the Rev. WENTWORTH WEBSTER, M.A.

Turkey-in-Asia. By J. C. MCCOAN, M.P.

Australia. By J. F. Vesey FitzGerald, late Premier of New South Wales.

Holland. By R. L. Poolr. 
Franc (Maude Jeane). The following form one Series, small post $8 \mathrm{vo}$, in uniform cloth bindings, with gilt edges:-

Emily's Choice. 5s.

Hall's Vineyard. $4 s$.

John's Wife: A Story of Life in

South Australia, $4 s$.

Marian; or, The Light of Some

One's Home. 5 s.

Francis (F.) War, W'aves, and Wanderings, including a Cruise in the "Lancashire Witch." 2 vols., crown 8vo, cloth extra, 24s.

French Revolution (The Great). Letters written from Paris sluring the Progress of the Great French Revolution, by Madame Jto her Husband and Son. Edited by her Great-grandson, M. EDOUARD Lockroy. From the French. Crown 8vo, cloth, Ios. $6 d$.

Froissart (The Boy's). Selected from the Chronicles of England, France, Spain, \&c. By SIDNeY Lanier. The Volume is fully Illustrated, and uniform with " The Boy's King Arthur." Crown 8vo, cloth, 7s. $6 d$.

From Newfoundland to Manitoba; a Guide through Canada's Maritime, Mining, and Prairie Provinces. By W. Fraser RAE. Crown 8vo, with several Maps, $6 s$.

GAMES of Patience. See Cadogan.

Gentle Life (Queen Edition). 2 vols. in r, small 4 to, ros. $6 d$.

\section{THE GENTLE LIFE SERIES.}

Price 6s. each ; or in calf extra, price Ios. 6d. ; Smaller Edition, cloth extra, 2s. $6 d$.

The Gentle Life. Essays in aid of the Formation of Character of Gentlemen and Gentlewomen. 2Ist Edition.

About in the World. Essays by Author of "The Gentle Life." Like unto Christ. A New Translation of Thomas à Kempis "De Imitatione Christi." 2nd Edition.

Familiar Words. An Index Verborum, or Quotation Handbook. Affording an immediate Reference to Phrases and Sentences that have become embedded in the English language. $6 s$.

Essays by Montaigne. Edited and Annotated by the Author of "The Gentle Life." With Portrait. 2nd Edition.

The Countess of Pembroke's Arcadia. Written by Sir PHILIP SIDNEY. Edited with Notes by Author of "The Gentle Life," 7s. $6 d$. The Gentle Life. and Series, 8th Edition. 
The Gentle Life Series (continued):-

The Silent Hour: Essays, Original and Selected. By the Author of "The Gentle Life." 3rd Edition.

Half-Length Portraits. Short Studies of Notable Persons. By J. HAIN FRISWELL.

Essays on English Writers, for the Self-improvement of Students in English Literature.

Other People's Windows. By J. HaIN Frisweld. 3rd Edition. A Man's Thoughts. By J. HaIn Friswell.

German Primer. Being an Introduction to First Steps in German. By M. T. PREU. 2s. $6 d$.

Getting On in the World; or, Hints on Success in Life. By W. MATHEWs, LL.D. Small post 8vo, cloth, 2s. $6 d$; ; gilt edges, 3 s. $6 d$. Gilpin's Forest Scenery. Edited by F. G. HEATH. Large post 8vo, with numerous Illustrations. Uniform with "The Fern World," $12 s .6 d$.

"Deserves to be a favourite in the boudoir as well as in the library."-Saturday Review.

"One of the most delightful works ever written."-Globe.

Gordon ( $J . E . H$.$) . See "Four Lectures on Electric Induc*$ tion," "Physical Treatise on Electricity," \& c.

Gouffe. The Royal Cookery Book. By Jules Goufré; translated and adapted for English use by ALPHONSE GourFí, Head Pastrycook to her Majesty the Queen. Illustrated with large plates printed in colours. I6I Woodcuts, 8vo, cloth extra, gilt edges, 2l. 2s. Domestic Edition, half-bound, Ios. $6 d$.

"By far the ablest and most complete work on cookery that has ever been submitted to the gastronomical world." - Pall Mall Gazette.

Great Artists. See "Biographies."

Great Historic Galleries of England (The). Edited by LoRD Ronald Gower, F.S.A., Trustee of the National Portrait Gallery. Illustrated by 24 large and carefully-executed permanent Photographs of some of the most celebrated Pictures by the Great Masters. Vol. I., imperial 4to, cloth extra, gilt edges, 36s. Vol. II., with 36 large permanent photographs, $£ 2$ I2s. $6 d$.

Great Musicians (The). A Series of Biographies of the Great Musicians. Edited by F. HUEFFER.

1. Wagner. By the EDITOR. 5. Rossini, and the Modern Italian

2. Weber. By Sir Julius . School. By H. SutherLand BENEDICT.

3. Mrendelssohn. By Joseph 6. Marcello. By ARRIGo BoITo. BENNETT.

4. Schubert. ByH. F.Frost. 8. English Church Composers.

*** Dr. Hiller and other distinguished writers, both English and Foreign, have promised contributions. Each Volume is complete in itself. Small post 8vo, cloth extra, 3 s. 
Guizot's History of France. Translated by ROBERT BLACK. Super-royal 8vo, very numerous Full-page and other Illustrations. In 8 vols., cloth extra, gilt, each $24 s$. This work is re-issued in cheaper Monthly Volumes, at Ios. 6d. each, commencing Nov. I, 188I. Subscription to the set, $£ 445$.

"It supplies a want which has long been felt, and ought to be in the hands of all students of history." -Times.

Masson's School Edition. The

History of France from the Earliest Times to the Outbreak of the Revolution ; abridged from the Translation by Robert Black, M.A., with Chronological Index, Historical and Genealogical Tables, \&c. By Professor Gustave Masson, B.A., Assistant Master at Harrow School. With 24 full-page Portraits, and many other Illustrations. I vol., demy $8 v 0,600$ pp., cloth extra, 1os. $6 i$.

Guizot's History of England. In 3 vols. of about 500 pp. each, containing 60 to 70 Full-page and other Illustrations, cloth extra, gilt, 24s, each.

"For luxury of typography, plainness of print, and beauty of illustration, these volumes, of which but one has as yet appeared in English, will hold their own against any production of an age so luxurious as our own in everything, typography not excepted." - Times.

Guyon (Mde.) Life. By Upham. 6th Edition, crown 8vo, 6s.

\section{$H^{A N D B O O K}$ to the Charities of London. See Low's.}

\section{of Emỏroidery; which see.}

Hall (W. W.) How to Live Long; or, 1408 Health Maxims, Physical, Mental, and Moral. By W. W. HaLl, A.M., M.D. Small post 8vo, cloth, 2s. 2nd Edition.

Harper's Monthly Magazine. Published Monthly. I60 pages, fully Illustrated. Is. With two Serial Novels by celebrated Authors.

Vol. I. December, 1850 , to May, I88r.

, II. May, I88r, to November, I88I.

Each cloth extra, with 400 magnificent illustrations, 8s, 6d.

" 'Harper's Magazine' is so thickly sown with excellent illustrations that to count them would be a work of time; not that it is a picture magazine, for the engravings illustrate the text after the manner seen in some of our choicest editions de luxe." St. Fames's Gazette.

"It is so pretty, so big, and so cheap. . . . An extraordinary shillingsworth160 large octayo pages, with over a score of articles, and more than three times as many illustrations." -Edinburgh Daily Reriicu.

"An amazing shillingsworth . . combining cholce literature of both nations." Nonconformist.

IIeart of Africa. Three Years' Travels and Adventures in the Unexplored Regions of Central Africa, from 1868 to $187 \mathrm{I}$. By Dr GEORG SCHWEINFURTH. Numerous Illustrations, ard large Map. 2 vols., crown $8 \mathrm{vo}$, cloth, 15 s.

Heath (Francis George). See "Autumnal Leaves," "Burnham Beeches," “Fern Paradise," "Fern World," "Gilpin's Forest Scenery," "Our Woodland Trees," "Peasant Life," "Sylvan Spring," "Trees and Ferns," "Where to Find Ferns." 
Heber's (Bishop) Mllustrated Edition of Hymns. With upwards of roo beautiful Engravings. Small 4to, handsomely bound, $7 s^{*} 6 d$. Morocco, $18 s .6 d$. and 2Is. New and Cheaper Edition, cloth, $3 s .6 d$. Heir of Kilfinnan (The). New Story by W. H. G. Kingston, Author of "Snow Shoes and Canoes," \&c. With Illustrations. Cloth, gilt edges, $7 s .6 d$. ; plainer binding, plain edges, $5 s$.

History of a Crume (The); Deposition of an Eye-witness. The Story of the Coup d'Etat. By VICTOR Hugo. Crown 8vo, 6s.

- Ancient Art. Translated from the German of JoHN WINCKELMANN, by JOHN LODGE, M.D. With very numerous Plates and Illustrations. 2 vols., 8vo, $36 s$.

- England. See Guizot.

- France. See Guizot.

— of Russia. See Rambaud. Merchant Shipping. See Lindsay. United States. See BRYANT.

History and Principles of Weaving by Hand and by Power. With several hundred Illustrations. By ALFRED BARLOW. Royal 8vo, cloth extra, 1 l. $5 s$. Second Edition.

Holmes (O.W.) The Poetical Works of Oliver Wendell Holmes. In 2 vols., I8mo, exquisitely printed, and chastely bound in limp cloth, gilt tops, Ios. $6 d^{\circ}$.

How I Crossed Africa: from the Atlantic to the Indian Ocean, Through Unknown Countries; Discovery of the Great Zambesi Affluents, \&c.-Vol. I., The King's Riffe. Vol. II., The Coillard Family. By Major SERPA YINTO. With 24 full-page and II8 halfpage and smaller Illustrations, ${ }_{3}$ small Maps, and I large one. 2 vols., demy $8 \mathrm{vo}$, cloth extra, $42 s$.

How to Live Long. See Hall.

How to get Strong and how to Stay so. By William Blaikie. A Manual of Rational, Physical, Gymnastic, and other Exercises. With Illustrations, small post $8 \mathrm{vo}, 5$ s.

Hugo (Victor) "Ninety-Three." Illustrated. Crown 8vo, 6s. boards, 2s. ; cloth, 2s. $6 d$.; On large paper with all the origina: Illustrations, ros. $6 \%$.

and his Times. Translated from the French of A. Barbou by ELLEN E. Frewer. I20 Illustrations, many of them from designs by Victor Hugo himself. Super-royal 8vo, cloth extra, 24s. Times," 
Hundred Greatest Men (The). 8 portfolios, 2 Is. each, or 4 vols., half morocco, gilt edges, I2 guineas, containing I5 to 20 Portraits each. See below.

"Messrs. SAMpson Low \& Co. are about to issue an important "International" work, entitled, 'THE HUNDRED GREATEST MEN ;' being the Lives and Portraits of the roo Greatest Men of History, divided into Eight Classes, each Class to form a Monthly Quarto Volume. The Introductions to the volumes are to be written by recognized authorities on the different subjects, the English contributors being Dean Stanley, Mr. Matrhew ARnold, Mr. Froude, and Professor Max Müllere: in Germany, Professor Helmholtz; in France, MM. Tains and Renan; and in America, Mr. Emerson. The Portraits are to be Reproductions from fine and rare Steel Engravings."-Academy.

Hygiene and Public Health (A Treatise on). Edited by A. H. Buck, M.D. Illustrated by numerous Wood Engravings. In 2 royal 8vo vols., cloth, one guinea each.

Hymnal Companion to Book of Common Prayer. See BICKERSTETI.

ILLUSTRATED Text-Books of Art-Education. Edited by EDWard J. Poynter, R.A. Each Volume contains numerous Illustrations, and is strongly bound for the use of Students, price 5s. The Volumes now ready are :-

\section{PAINTING.}

Classic and Italian. By PerCY German, Flemish, and Dutch.

R. HEaD. With 50 Illustrations, French and Spanish.

5 s.

English and American.

ARCHITECTURE.

Classic and Farly Christian.

Gothic and Renaissance. By T. Roger Smith. With 50 Illustra. tions, 5 .

\section{SCULPTURE.}

Antique: Egyptian and Greek. I Renaissance and Modern. Italian Sculptors of the 14th and 15th Centuries.

Decoration in Colour. | | Architectural Ornament.

Illustrations of China and its People. By J. Thompson, F.R.G.S. Four Volumes, imperial 4to, each 3 l. 3 s.

Illustrated Dictionary (An) of Words used in Art and Archroology. Explaining Terms frequently used in Works on Architecture, Arms, Bronzes, Christian Art, Colour, Costume, Decoration, Devices, Emblems, Heraldry, Lace, Personal Ornaments, Pottery, Painting, Sculpture, \&c., with their Derivations. By J. W. MolLETT, B.A., Officier de l'Instruction Publique (France); Author of "Life of Rembrandt," \&c. Illustrated with 600 Wood Engravings. Small 4to, strongly bound in cloth, 12s, $6 d$.

In my Indian Garden. By PhiL Robinson, Author of "Under the Purkah." With a Preface by EDWIN ARNold, M.A., C.S.I., \&c. Crown 8vo, limp cloth, 3s. 6d. 
Involuntary Voyage $(A n)$. Showing how a Frenchman who abhorred the Sea was most unwillingly and by a series of accidents driven round the World. Numeious Illustrations. Square crown $8 \mathrm{vo}$, cloth extra, 7s. $6 d$.; plainer binding, plain edges, 5 s.

Irving (Washington). Complete Library Edition of his Works in 27 Vols., Copyright, Unabridged, and with the Author's Latest Revisions, called the "Geoffrey Crayon" Edition, handsomely printed in large square $8 \mathrm{vo}$, on . superfine laid paper, and each volume, of about 500 pages, will be fully Illustrated. $125.6 d$. per vol. See also "Little Britain."

FACK and $\mathscr{7}$ ill. By Miss Alcotт. Small post 8vo, cloth, gilt edges, ${ }_{5} \mathrm{~s}$. With numerous Illustrations.

John Holdsworth, Chief Mate. By W. Clarke Russell, Author of "Wreck of the Grosvenor." Crown 8vo, $6 s$.

KINGSTON (W. H. G.). See "Snow-Shoes," "Child of the Cavern," "Two Supercargoes," "With Axe and Rifle," "Begum's Fortune," "Heir of Kilfinnan," "Dick Cheveley." Each vol., with very numerous Illustrations, square crown $16 \mathrm{mo}$, gilt edges, 7s. $6 d$.; plainer binding, plain edges, $5 s$.

\section{LADY Silzerdale's Sreetheart. 6s. See BLACK.}

Lectures on Architecture. By E. Vrollet-LE-Duc. Translated by Benjamin Bucknall, Architect. With 33 Steel Plates and 200 Wood Engravings. Super-royal 8vo, leather back, gilt top, with complete Index, 2 vols., $3 l .3 s$.

Lenten Meditations. In Two Series, each complete in itself. By the 'Rev. Claude Bosanquet, Author of "Blossoms from the Kying's Garden." I6mo, cloth, First Series, Is. 6d.; Second Series, 2s. Library of Religious Poetry. A Collection of the Best Poems of all Ages and Tongues. With Biographical and Literary Notes. Edited by PhILIP SChafr, D.D., LL.D., and Arthur Gilman, M.A. Royal 8vo, pp. 1036, cloth extra, gilt edges, 21s.

Lindsay (W. S.) History of Merchant Shipping and Ancient Commerce. Over 150 Illustrations, Maps, and Charts. In 4 vols., demy $8 \mathrm{vo}$, cloth extra. Vols. I and 2, 21s. ; vols. 3 and 4, 24s. each. Little Britain; together with The Spectre Bridegroom, and $A$ Legend of Sleepy Hollow. By Washington IRving. An entirely New Edition de latxe, specially suitable for Presentation. Illustrated by 120 very fine Engravings on Wood, by Mr. J. D. COOPER. Designed by Mr. Charles O. Murrax. Square crown $8 \mathrm{vo}$, cloth extra, gilt edges, ros. $6 d$. 
Low's Select Novelets. Small post 8vo, cloth extra, 3s. $6 d$. each.

Eriends: a Duet. By E. S. PHeLPS, Author of "The Gates Ajar."

" 'Friends' is a graceful story ... it loses nothing in the telling."-Athenctem.

Baby Rue: Her Adventures and Misadventures, her Friends and her Enemies. By Charles M. Clay.

The Story of Helen Troy.

"A plcasant book."-Truth.

The Clients of Dr, Bernagius. From the French of LucieN Biart, by Mrs. Cashel. Hoey.

The Undiscovered Country. By W. D. Howells.

A Gentleman of Leisure. By Edgar Fawcert.

"An amazingly clever book."-Boston Transcript.

Low's Standard Library of Travel and Adventure. Crown 8vo, bound uniformly in cloth extra, price $7 s .6 d$.

I. The Great Lone Land. By Major W. F. BuTLER, C.B.

2. The Wild North Land. By Major W. F. Butler, C.B.

3. How I found Livingstone. By H. M. STANLEY.

4. The Threshold of the Unknown Region. By C. R. MARKHAM. (4th Edition, with Additional Chapters, Ios. 6d.)

5. A Whaling Cruise to Baffin's Bay and the Gulf of Boothia. By A. H. MARKHAM.

6. Campaigning on the Oxus. By J. A. MacGaHaN.

7. Akim-foo: the History of a Failure. By Major W. F. Butler, C.B.

8. Ocean to Ocean. By the Rev. George M. Grant. With Illustrations.

9. Cruise of the Challenger. By W. J. J. Spry, R.N.

10. Schweinfurth's! Heart of Africa. 2 vols., 15 s.

II. Through the Dark Continent. By H. M. STANLeY. I vol., 12s. $6 d$.

Low's Standard Novels. Crown 8vo, 6s. each, cloth extra.

My Lady Greensleeves. By HeLen Mathers, Authoress of "Comin' through the Rye," "Cherry Ripe," \&c.

Three Feathers. By William Black.

A Daughter of Heth. 13th Edition, By W. BLACR. With Frontispiece by F. WALKER, A.R.A.

Kilmeny. A Novel. By W. BLAck.

In Silk Attire. By W. BLACK.

Lady Silverdale's Sweetheart. By W. Black.

sunrise. By W. Black.

The Trumpet Major. By Thomas Hardy.

An English Squire. By Miss Coleridgr. 
Lowe's Standard Novels (continued):-

Mary Marston. By GEORGE MacDonald.

Guild Court. By George MaCDonald.

The Vicar's Daughter. By George Macdonald.

Adela Cathcart. By George Macdonald.

Out of Court. By Mrs. Cashel Hozy.

History of a Crime: The Story of the Coup d'État. VICTOR HUGo.

Alice Lorraine. By R. D. BLACKMORE.

- Lorna Doone. By R. D. Blackmore. I8th Edition,

Cradock Nowell. By R. D. BlackMore.

Clara Vaughan. By R. D. BlACKMORE.

Cripps the Carrier. By R. D. BLACKMore.

Erema; or, My Father's Sin. By R. D. Blackmore.

Mary Anerley. By R. D. BlackmoRe.

Christowell, a Dartmoor Tale. By R. D. Blackmore.

Innocent. By Mrs. Oliphast. Eight Illustrations.

Work. A Story of Experience. By Louisa M. ALcott.

The Afghan Enife. By R. A. Strrndale, Author of "Seonee",

A French Heiress in her own Chateau. By the Author of "One Only," "Constantia," \&c. Six Illustrations.

Ninety-Three. By Victor HUGO. Numerous Illustrations.

My wife and I. By Mrs. BeEcher Stowe.

Wreck of the Grosvenor. By W. Clark Russeit.

John Holdsworth (Chief Mate). By W. CLARK RUSSELl.

A Sailor's Sweetheart. By W. CLARK RUSSELl.

Far from the Madding Crowd. By Thomas Hardy.

Elinor Dryden. By Mrs. MacquoID.

Diane. By Mrs. MacQuoID.

Poganuc People, Their Loves and Lives. By Mrs. B. Stowe.

A Golden Sorrow. By Mrs. Cashel Hoey.

Out of Court. By Mrs. Cashei Hoey.

A story of the Dragonnades. By the Rev. E. Gilliat, M.A.

Low's Handbook to the Charities of London. Edited and revised to date by C. MACKeson, F.S. S., Editor of "A Guide to the Churches of London and its Suburbs," \&c. Paper, Is. ; cloth, Is. 6d.

MAGREGOR (John) "Rob Roy" on the Baltic. 3rd Edition, small post $8 \mathrm{vo}, 2 s$. $6 d$. ; cloth, gilt edges, $3 s .6 d$.

A Thousand Miles in the "Rob Roy" Canoe. I Ith Edition, small post $8 \mathrm{vo}, 2 s .6 d$.; cloth, gilt edges, $3 s .6 d$. 
Macgregor (John) Description of the "Rob Roy" Canoe, with Plans, \&c., is.

The Voyage Alone in the Yawl "Rob Roy." New

Edition, thoroughly, revised, with additions, small post $8 \mathrm{vo}, 5 s$. ; boards, 2s. $6 d$.

Macquoid (Mrs.) Elinor Dryden. Crown 8vo, cloth, $6 s$. Diane. Crown 8vo, 6s.

Magazine. See Harper, Union JaCK, The Etcher, MeN OF MARK.

Magyarland. A Narrative of Travels through the Snowy Carpathians, and Great Alfold of the Magyar. By a Fellow of the Carpathian Society (Diploma of I88I), and Author of "The Indian Alps." 2 vols., 8vo, cloth extra, with about I20 Woodcuts from the Author's own sketches and drawings, 42s.

Manitoba : its History, Growth, and Present Position. By the

Rev. Professor BRYCE, Principal of Manitoba College, Winnipeg. Crown 8vo, with Illustrations and Maps, $7 s .6 d$.

Markham (C. R.) The Threshold of the Unknown Region. Crown 8vo, with Four Maps, 4th Edition. Cloth extra, ros. 6d.

Maury (Commander) Physical Geography of the Sea, and its Meteorology. Being a Reconstruction and Enlargement of his former Work, with Charts and Diagrams. New Edition, crown 8vo, 6s.

Memoirs of Count Miot de Melito, Minister, Ambassador, Councillor of State, and Member of the Institute of France, betweén the years 1788 and I815. Edited by General FLEIschmaNn. From the French by Mrs. CAShel Hory and Mr. JOHN Lillie. 2 vols., demy 8vo, cloth extra, $36 s$.

Memoirs of Madame de Rémusat, 1802-1808. By her Grandson, M. Paul DE Rémusat, Senator. Translated by Mrs. Casher HoEY and Mr. JoHN LILIIE. 4th Edition, cloth extra. This work was written by Madame de Rémusat during the time she was living on the most intimate terms with the Empress Josephine, and is full of revelations respecting the private life of Bonaparte, and of men and politics of the first years of the century. Kevelations which have already created a great sensation in Paris. $8 \mathrm{ro}, 2$ vols., $3^{25}$. See also "Selection."

Menus (366, one for each day of the year). Translated from the French of Count Brisse, by Mrs. Matthew Clarke. Crown 8vo, IOs. $6 d$.

Men of Mark: a Gallery of Contemporary Portraits of the most Eminent Men of the Day taken from Life, especially for this publica. tion, price Is. 6d. monthly. Vols. I. to VI., handsomely bound, cloth, gilt edges, 25s. each. 
Mendelssohn Family (The), I 729-I847. From Letters and Journals. Translated from the German of SEBASTIAN HENSEL. 2 vols., demy $8 \mathrm{vo}, 30$.

Michael Strogoff. Ios. 6d. and 5s. See VERNE. Mitford (Miss). See "Our Village."

Music. See "Great Musicians."

My Lady Greensleeves. By Helen Mathers, Authoress of "Comin' through the Rye," "Cherry Ripe," \&c. I vol. edition, crown $8 \mathrm{vo}$, cloth, $6 s$.

Mysterious Island. By Jules Verne. 3 vols., imperial i $6 \mathrm{mo}$, I50 Illustrations, cloth gilt, 35. 6d. each ; elaborately bound, gilt edges, $7 s .6 d$. each. Cheap Fdition, with some of the Illustrations, cloth, gilt, $2 s$. ; paper, $1 s$. each.

NARRATIVES of State Trials in the Nineteenth Century.

First Period: From the Union with Ireland to the Death of George IV., I80I-1830. By G. Lathom Browne, of the Middle Temple, Barrister-at-Law. 2 vois., crown 8vo, cloth, 24s.

Nature and Functions of Art (The); and more especially of Architecture. By LeOpold EIDLitz. Medium 8vo, cloth, 21s. Naval Brigade in South Africa (The). By Henry F. NorBURY, C.B., R.N. Crown 8vo, cloth extra, Ios. $6 d$.

Nezo Child's Play $(A)$. Sixteen Drawings by E. V. B. Beautifully printed in colours, 4to, cloth extra, I2s. $6 d$.

New Guinea: What I did and what I saze. By L. M. D'AlBER TIS, Officer of the Order of the Crown of Italy, Honorary Member and Gold Medallist of the I.R.G.S., C.M.Z.S., \&c., \&c. In 2 vols., demy 8vo, cloth extra, with Maps, Coloured Plates, and numerous very fine Woodcut Illustrations, $42 s$.

New Ireland. By A. M. Sullivar, M.P. for Louth. 2 vols., demy $8 \mathrm{vo}$, 30 s. Cheaper Edition, I vol, crown 8vo, 8s. $6 d$.

New Novels. Crown 8vo, cloth, ros. 6d. per vol. :-

Christowell : a Dartmoor Tale. By R. D. BLACKMoRe. 3 vols. The Braes of Yarrow. By CHAS. GIBBon. 3 vols.

A Laodicean. By Thomas HardX, Author of. "Far from the Madding Crowd," “Trumpet Major," \&c., \&c. 3 vols.

waiting. By Miss A. M. Hopkinson. 3 vols.

Don John. By Miss JEAN INGELOW. 3 vols.

Warlock of Warlock. By GEORGe MACDONALD, 3 vols.

Riverside Papers. By J. D. Hoppus. 2 vols., small post 8vo, I2s.

Cecily's Debt. By Mrs. A. B. Church. 3 vols.

Nice and Her Neighbours. By the Rev. CANON HoLE, Author of "A Book about Roses," "A Little Tour in Ireland," \&c. Small 4to, with numerous choice Illustrations, $₫ 2 s$. $6 d$. 
Noah's Ark. A Contribution to the Study of Unnatural History.

By PhIL Robinson, Author of "In my Indian Garden," "Under the Punkah," \&c., \&c. 2 vols. Small post 8vo, 12s. 6d.

Noble Words and Noble Deeds. From the French of E. Muller. Containing many Full-page Illustrations by PHilippoteaux. Square imperial I6mo, cloth extra, 7s. 6d.; plainer binding, plain edges, 5.

Nordenskiöld's Voyage around Asia and Europe. A Popular Account of the North-East Passage of the "Vega." By Lieut. A. HOVGAARD, of the Royal Danish Navy, and member of the "Vega" Expedition. Demy 8vo, cloth, with about 50 Tllustrations and 3 Maps, 2Is.

North American Review (The). Monthly, price 2s. $6 d$. Nolhing to Wear; and Tro Millions. By W. A. Butler. New Edition. Small post 8vo, in stiff coloured wrapper, Is.

Nursery Playmates (Prince of). 217 Coloured Pictures for Children by eminent Artists. Folio, in coloured boards, $6 s$.

$O^{F F}$ to the Wilds: A Story for Boys. By G. Manville FENN. Most richly and profusely Illustrated. Crown 8vo, cloth extra, 7s. $6 d$.

Old-Fashioned Girl. See AlcotT.

On Horseback through Asia Minor. By Capt. Fred Burnaby, Royal Horse Guards, Author of "A Ride to Khiva." 2 vols., 8vo, with three Maps and Portrait of Author, 6th Edition, 38s.; Chenper Edition, crown 8vo, Ios. $6 d$.

Our Little Ones in Heaven. Edited by the Rev. H. Robsins. With Frontispiece after Sir JoshUA Reynolds. Fcap., cloth extra, New Edition-the 3rd, with Illustrations, 5 s.

Our Village. By MaRy Russell Mitford. Illustrated with Frontispiece Steel Engraving, and 12 full-page and 157 smaller Cuts. Crown 4to, cloth, gilt edges, $2 \mathrm{I} s$. ; cheaper binding, $10 s .6 d$.

Our Woodland Trees. By F. G. Heath. Large post 8vo, cloth, gilt edges, uniform with "Fern World " and "Fern Paradise," by the same Author. 8 Coloured Plates (showing leaves of every British Tree) and 20 Woodcuts, cloth, gilt edges, 12s. 6d. Third Edition. About 600 pages.

Outlines of Ormament in all Styles. A Work of Reference for the Architect, Art Manufacturer, Decorative Artist, and Practical Painter. By W. and G. A. AudsLey, Fellows of the Royal Institute of British Architects. Only a limited number have been printed and the stones destroyed. Small folio, bo plates, with introductory text, cloth gilt, $3 \mathrm{Is} .6 d$. 
PAINTERS of All Schools. By Louis VIardot, and other

Writers. 500 pp., super-royal $8 \mathrm{vo}$, 20 Full-page and yo smaller Engravings, cloth extra, 25s. A New Edition is issued in Half. crown parts, with fifty additional portraits, cloth, gilt edges, $3^{\mathrm{I} s}$. $6 d$.

Painting ( $A$ Short History of the British School of). By Geo. H. Shepherd. Post 8vo, cloth, 3 s. $6 d$.

Palliser (Mrs.) A History of Lace, from the Earliest Period. A New and Revised Edition, with additional cuts and text, upwards of 100 Illustrations and coloured Designs. I vol, , 8vo, Il. Is.

Historic Devices, Badges, and War Cries. 8vo, il. is. The China Collector's Pocket Companion. With upwards of 1000 Illustrations of Marks and Monograms. 2nd Edition, with Additions. Small post 8vo, limp cloth, 5s.

Parliamentary History of the Irish Land Question (The). From I 829 to 1869 , and the Origin and Results of the Ulster Custom. By R. BARRY O'BRIEN, Barrister-at-Law, Author of "The Irish Land Question and English Public Opinion." 3rd Edition, corrected and revised, with additional matter. Post $8 \mathrm{vo}$, cloth extra, $6 s$.

Pathways of Palestine: a Descriptive Tour through the Holy Land. By the Rev. Canon Tristram. Illustrated with 44 permanent Photographs. (The Photographs are large, and most perfect Specimens of the Art.) Published in 22 Monthly Parts, 4to, in Wrapper, $2 s$. $6 d$. each. Vol. I., containing I2 parts, 24 Illustrations, cloth, gilt edges, $31 s, 6 d$.

Peasant Life in the West of England. By FRANCIS GeORGE HeAth, Author of "Sylvan Spring," "The Fern World." Crown $8 v 0,400 \mathrm{pp}$. (with Autograph Letter of seven pages from Lord Beaconsfield to the Author, written December 28, 1880), 10s. $6 d$.

Petites Leçons de Conversation et de Grammaire: Oral and Conversational Method; being Lessons introducing the most Useful Topics of Conversation, upon an entirely new principle, \&c. By F. Jul.IEN, French Master at King Edward the Sixth's School, Birmingham. Author of "The Student's French Examiner," "First Steps in Conversational French Grammar," which see.

Photography (History and Handbook of). See Tissandier.

Physical Treatise on Electricity and Magnetism: By J. E. H. GORDON, B.A. With about 200 coloured, full-page, and other Illustrations. In respect to the number and beauty of the Illustrations, the work is quite unique. 2 vols., $8 \mathrm{vo}, 36$ s.

Poems of the Inner Life. A New Edition, Revised, with many additional Poems. Small post 8vo, cloth, 5s. 
Poganuc People: their Loves and Lives. By Mrs. BeEcher STowe. Crown 8vo, cloth, 6s.

Polar Expeditions. See Koldewey, Markham, MacGahaN, NARES, and NORDENSKIÖLD.

Poynter (Edzeard J., R.A.). See "Illustrated Text-books."

Publishers' Circular (The), and General Record of British and Foreign Literature. Published on the Ist and I5th of every Month, $3^{d}$.

Pyrenees (The). By Henry BlackBurn. With Ioo Illustrations by Gustave Dorí, a New Map of Routes, and Information for Travellers, corrected to $188 \mathrm{I}$. With a description of Lourdes in $\mathbf{1 8 8 0}$.

Crown 8vo, cloth extra, $7 s, 6 d$.

$R^{A M B A U D}$ (Alfred). History of Russia, from its Origin to the Year Y87\%. With Six Maps. Translated by Mrs. L. B. LANE. 2 vols., demy 8vo, cloth extra, $38 s$.

Recollections of Writers. By Charles and Mary Cowden Clarke. Authors of "The Concordance to Shakespeare," \&c. ; with Letters of Charles LAMB, Leigh Hunt, Douglas JerRold, and Charles Dickens; and a Preface by Mary Cowden Clarke. Crown 8vo, cloth, 10s. $6 d$.

Rémusat (Madame de). See "Memoirs of," "Selection."

Richter (Jean Paul). The Literary Works of Leonardo da Vinci. Containing his Writings on Painting, Sculpture, and Architecture, his Philosophical Maxims, Humorous Writings, and Miscellaneous Notes on Personal Events, on his Contemporaries, on Litera. ture, \&c. ; for the first time published from Autograph Manuscripts. By J. P. RICHTER, Ph.Dr., Hon. Member of the Royal and Imperial Academy of Rome, \&c. 2 vols., imperial $8 \mathrm{vo}$, containing about 200 Drawings in Autotype Reproductions, and numerous other Illustrations. Price Eight Guineas to Subscribers. After publication the price will be Ten Guineas.

Robinson (Phil). See "In my Indian Garden," "Under the Punkah," "Noah's Ark."

Rochefoucauld's Reflections. Bayard Series, 2s. 6d.

Rogers (S.) Pleasures of Memory. See "Choice Editions of Choice Books." 2s. 6d.

Rose in Bloom. See AlcotT. 
Rose Library (The). Popular'Literature of all Countries. Each volume, 1s. ; cloth, 2s. $6 d$. Many of the Volumes are Illustrated-

I. Sea-Gull Rock. By Jules SANDeau. Illustrated.

2. Little Women. By LouIsA M. AIcotr.

3. Little Women Wedded. Forming a Sequel to "Little Women."

4. The House on Wheels. By MADAME DE STOLz. Illustrated.

5. Little Men. By Louisa M. AxcotT. Dble. vol., 2s.; cloth, $35.6 d$.

6. The Old-Fashioned Girl. By LoUISA M. AlcotT. Double vol., 2s. ; cloth, 3s. $6 d$.

7. The Mistress of the Mranse. By J. G. Holland.

8. Timothy Titcomb's Letters to Young People, Single and Married.

9. Undine, and the Two Captains. By Baron DE LA MotTe FouQuE. A New Translation by F. E. BunNETT. Illustrated.

Io. Draxy Mriller's Dowry, and the Elder's Wife. SAXE HoLM.

II. The Four Gold Pieces. By Madame Govraud. Illustrated.

I2. Work. A Story of Experience. First Portion. By L. M. ALcotT.

13. Béginning Again. Sequel to above. By L. M. AlcotT.

I4. Picciola; or, the Prison Flower. X. B. SAINTINE. Illustrated.

15. Robert's Holidays. Illustrated.

16. The Two Children of St. Domingo. Numerous Illustrations.

17. Aunt Jo's Scrap Bag.

18. Stowe (Mrs. H. B.) The Pearl of Orr's Island.

19. - - The Minister's Wooing.

20. - Betty's Bright Idea.

21. - The Ghost in the Mrill.

22. Captain Kidd's Mroney.

23. - We and our Neighbours. Double vol., 2s.

24. My Wife and I. Double vol., 2s. ; cloth, gilt, 3s. $6 d$.

25. Hans Brinker ; or, the Silver Skates.

26. Lowell's Mry Study Window.

27. Holmes (O. W.) The Guardian Angel.

28. Warner (C. D.) My Summer in a Garden.

29. Hitherto. By the Author of "The Gayworthys." 2 vols., Is. each.

30. Helen's Babies. By their Latest Victim.

3. The Barton Experiment. . By the Author of "Helen's Babies."

32. Dred. Mrs. BeEcher StowE. Dble. vol., $2 s$; cloth gilt, $3 s .6 d$.

33. Warner (C. D.) In the Wilderness.

34. Six to One. A Seaside Story.

35. Nothing to Wear, and Two Millions.

36. Farm Ballads. By Will CarLeton.

37. Farm Festivals. By Will Carleton.

38. Farm Legends. By Will Carleton.

39 and 40 . The Clients of Dr. Bernagius. BiART. Parts I. \& II. 4T. Baby Rue; her Adventures and Misadventures. C. M. CLAY. 42. The Undiscovered Country. By W. D. HowELLS.

43. Friends : a Duet. By Elizabeth Stuart Phelps.

44. A Gentleman of Leisure. A Novel. By EDGar FawcetT.

45. The Story of Felen Troy. 
Round the Yule Log: Norwegian Folk and Fairy Tales.

Translated from the Norwegian of P. CHR. AsBJörnsEN. With 100

Illustrations. Imperial I6mo, cloth extra, gilt edges, $7 s .6 d$.

Russell (W. Clarke). See "A Sailor's Sweetheart," 3 vols., $31 s .6 \mathrm{~d}$.; "Wreck of the Grosvenor," 6s. ; "John Holdsworth (Chief Mate)," $6 s$.

Russell (W. H., LL.D.) Hesperothen: Notes from the Western World. A Record of a Ramble through part of the United States, Canada, and the Far West, in the Spring and Summer of I88I. By W. H. Russeli, LL. D. 2 vols., crown $8 \mathrm{vo}$, cloth, $24 s$.

The Tour of the Prince of Wales in India. By W. H. Russele, LL.D. Fully Illustrated by SyDNEY P. HALI, M.A. Super-royal 8vo, cloth extra, gilt edges, 52s. 6d.; Large Paper Edition, 84s.

SAINTS and their Symbols: A Companion in the Churches and Picture Galleries of Europe. With Illustrations. Royal $16 \mathrm{mo}$, cloth extra, 3s. 6d.

Science Ladders. Fcap. 8vo, stiff covers, $6 d$. each.

Series I.

No. I. Forms of Land and Water. With 15 Illustrations.

" II. The Story of Early Exploration.

SERIES II.

" I. Vegetable Life. With 35 Illustrations.

", II. Flowerless Plants.

SERIES III.

"I. Lowest Forms of Water Animals. With 22 Illustrations.

"II. Lowly Mrantie and Armour-Wearers.

Schuyler (Eugène). The Life of Peter the Great. By EugÈNE SCHUYLER, Author of "Turkestan." 2 vols., demy 8vo, cloth extra.

Selection from the Letters of Madame de Rémusat to her Husband and Son, from 1804 to 1813 . From the French, by Mrs. CASHEL HoEY and Mr. JoHN LILLIE. In I vol., demy 8vo (uniform with the "Memoirs of Madame de Rémusat," 2 vols.), cloth extra, 16 s.

Seonee: Sporting in the Satpura Range of Central India, and in the Valley of the Nerbudda. By R. A. STERNDALE, F.R.G.S. 8vo, with numerous Illustrations, 21 s.

Seven Years in South Africa: Travels, Researches, and Hunting Adventures between the Diamond-Fields and the Zambesi (18721879). By Dr. EMIL HOLUB. With over Ioo Original Illustrations and 4 Maps. In 2 vols., demy 8vo, cloth extra, 42s. 
Serpent Charmer (The): a Tale of the Indian Mutiny. From the French of Louis RousseleT. Numerous Illustrations. Crown $8 \mathrm{vo}$, cloth extra, gilt edges, 7s. $6 \mathrm{~d}$.; plainer binding, $5 \mathrm{~s}$.

Shadbolt (S.) The Afghan Campaigns of $1878-\mathrm{r} 880$. By Sydney Shadbolt, Joint Author of "The South African Campaign of 1879." Dedicated by permission to Major-General Sir Frederick Roberts, G.C.B., V.C., \&c. 2 vols., royal quarto, cloth extra; to suto scribers before publication, $2 l$. Ios. ; to non-subscribers, $3 l$.

Shooting: its Appliances, Practice, and Purpose. By James Dalzier, Dougald, F.S.A., F.Z.A., Author of "Scottish Field Sports," \&c. New Edition, revised with additions. Crown 8vo, cloth extra, 7s. $6 d$.

"The book is admirable in every way. . . . . We wish it every success."-Globe.

"A very complete treatise. . . . Likely to take high rank as an authority on shooting."-Daily News.

Sikes (Wirt). Rambles and Studies in Old South Wales. With numerous Illustrations. Demy 8vo, cloth extra, I8s, By WIRT SIKES, Author of "British Goblins," which see.

Silent Hour (The). See "Gentle Life Series."

Silver Sockets (The); and other Shadowes of Redemption. Eighteen Sermons preached in Christ Church, Hampstead, by the Rev. C. H. WALIER. Small post 8vo, cloth, $6 s$.

Smith (G.) Assyrian Explorations and Discoveries. By the late GroRge Smitr. Illustrated by'Photographs and W.oodcuts. Demy 8vo, 6th Edition, 18s.

The Chaldean. Account of Genesis. By the late G. SMITH, of the Department of Oriental Antiquities, British Museum. With many Illustrations. Demy 8vo, cloth extra, 6th Edition, 16s. An entirely New Edition, completely revised and re-written by the Rev. Professor Sayce, Queen's College, Oxford. Demy 8vo, 18 s.

Snow-Shoes and Canoes; or, the Adventures of a Fur-Hunter in the Hudson's Bay Territory. By W. H. G. Kingston. 2nd Edition. With numerous Illustrations. Square crown 8vo, cloth extra, gilt edges, 7s. 6d.; plainer binding, $5 s$.

South African Campaign, I879 (The). Compiled by J. P. MACKINNON (formerly 72 nd Highlanders), and S. H. SHADBOLT; and dedicated, by permission, to Field-Marshal H.R.H. The Duke of Cambridge. 4to, handsomely bound in cloth extra, 2l. 10s.

Stanley (H. M.) How I Found Livingstone. Crown 8vo, cloth extra, 7s. 6d.; large Paper Edition, Ios. 6d. 
Stanley (H. M.) "My Kalulu," Prince, King, and Slave. A Story from Central Africa. Crown $8 v 0$, about $430 \mathrm{pp}$, with numerous graphic Illustrations, after Original Designs by the Author. Cloth, 7s. $6 d$.

- Coomassie and Magdala. A Story of Two British Campaigns in Africa. Demy 8vo, with Maps and Illustrations, 16 s.

-- Through the Dark Continent, which see.

Story without an End. From the German of Carové, by the late Mrs. SaraH T. Austin. Crown 4to, with 15 Exquisite Drawings by $E$. V. B., printed in Colours in Fac-simile of the original Water Colours; and numerous other Illustrations. New Edition, 7 s. $6 d$. square 4to, with Illustrations by Harvey. 2s. $6 d$.

Stowe (Mrs. Beecher) Dred. Cheap Edition, boards, 2s. Cloth, gilt edges, $3 s .6 d$.

Footsteps of the Master. With Illustrations and red borders. Small post 8vo, cloth extra, $6 s$.

Geography, with 60 Illustrations. Square cloth, $45.6 d$. Little Foxes. Cheap Edition, Is.; Library Edition, 4. $6 d$.

Betty's Bright Idea. Is.

My Wife and I; or, Harry Henderson's History. Small post 8vo, cloth extra, 6s.*

Minister's Wooing. 5s.; Copyright Serries, 1s. $6 d_{\text {.; }}$ cl., 2s.* Old Town Folk. 6s.; Cheap Edition, 2s. 6d. Old Town Fireside Stories. Cloth extra, 3s. 6d. Our Folks at Poganuc. 6 s.

We and our Neighbours. I vol., small post 8vo, 6 s. Sequel to "My Wife and I."

Pink and White Tyranny. Small post 8vo, 3s. 6d. Cheap Edition, 1s. $6 d$. and 2s. 
Stowe (Mrs. Beecher) Queer Little People. Is.; cloth, $2 s$. Chimney Corner. Is. ; cloth, Is. $6 d$. The Pearl of Orr's Island. Crown 8vo, $5^{s . *}$ Woman in Sacred History. Illustrated with I5 Chromo-lithographs and about 200 pages of Letterpress. Demy 4to, cloth extra, gilt edges, 25.

Student's French Examiner. By F. JuLIEN, Author of "Petites Leçons de Conversation et de Grammaire." Square cr. 8vo, cloth, $2 s$.

Studies in the Theory of Descent. By Dr. Aug. Weismann, Professor in the University of Freiburg. Translated and edited by RAPHAEL MELDOLA, F.C.S., Secretary of the Entomological Society of London. Part I.- "On the Seasonal Dimorphism of Butterflies," containing Original Communications by Mr. W. H. EDWARDS, of Coalburgh. With two Coloured Plates. Price of Part. I. (to Subscribers for the whole work only), $8 s$; Part II. (6 coloured plates), I6s. ; Part III., 6s.

Sunrise: A Story of These Times. By William Black, Author of "A Daughter of Heth," \&c. Crown 8vo, cloth, 6s.

Surgeon's Handbook on the Treatment of Wounded in War. By Dr. FrIEDRICH Esmarcir, Surgeon-General to the Prussian Army. Numerous Coloured Plates and Illustrations, 8vo, strongly bound, 1. $8 s$.

Sylvan Spring. By Francis George Heatr. Illustrated by I2 Coloured Plates, drawn by, F. E. Hulme, F.L.S., Artist and Author of "Familiar Wild Flowers;" by 16 full-page, and more than Ioo other Wood Engravings. Large post 8vo, cloth, gilt edges, $12 s .6 d$. TAINE (H. A.) "Les Origines de la France Contemporaine."

Vol. I. The Ancient Regime. Demy 8vo, cloth, I6s.

Vol. 2. The French Revolution. Vol. $\mathrm{r}$. do.

Vol. 3. Do. do. Vol. $\dot{2}$. do.

Tauchnitz's English Editions of German Authors. Each volume, cloth flexible, $2 s_{\text {. }}$; or sewed, $1 s .6 d$. (Catalogues post free on application.) roan, $2 s$,

(B.) German and English Dictionary. Cloth, Is. 6d.; - See elso Rose Library. 
Tauchnitz's French and English Dictionary. Paper, Is. 6d.; cloth, 2s.; roan, $2 s .6 d$.

Italian and English Dictionary. Paper, Is. 6d.; cloth, 2s. ; roan, $2 s .6 d$.

Spanish and English. Paper, Is. $6 d$. ; cloth, $2 s_{\text {. }}$; roan 2s. $6 d$.

Through America; or, Nine Months in the United States. By W. G. Marshall, M.A. With nearly Ioo Woodcuts of Views of Utah country and the famous Yosemite Valley; The Giant Trees, New York, Niagara, San Francisco, \&c.; containing a full account of Mormon Life, as noted by the Author during his visits to Salt Lake City in 1878 and 1879. Demy 8vo, 21s; cheap edition, crown 8vo, 7s. $6 d$.

Through the Dark Continent: The Sources of the Nile; Around the Great Lakes, and down the Congo. By H. M. STANLEY. Cheap Edition, crown 8vo, with some of the Illustrations and Maps, 12s. $6 d$.

Through Siberia. By the Rev. Henry Lansdell. Illustrated with about 30 Engravings, 2 Route Maps, and Photograph of the Author, in Fish-skin Costume of the Gilyaks on the Lower Amur. 2 vols., demy $8 \mathrm{vo}, 30$.

Tour of the Prince of Wales in India. See Russell

Trees and Ferns. By F. G. Heath, Crown 8vo, cloth, gilt edges, with numerous Illustrations, $3 s .6 d$.

"A charming little volume."-Land and Watcr.

Tristram (Rev. Canon) Pathways of Palestine: A Descriptive Tour through the Holy Land. First Series. Illustrated by 22 Permanent Photographs. Folio, cloth extra, gilt edges, 31s. $6 d$.

Treo Friends. By Lucien Brart, Author of "Adventures of a Young Naturalist," "My Rambles in the New World," \&c. Small post $8 \mathrm{vo}$, numerous Illustrations, gilt edges, $7 s$. $6 d_{\text {. }}$; plainer binding, $5 s^{\text {. }}$

Two Supercargoes (The); or, Adventures in Savage Africa. By W. H. G. KingsTon. Numerous Full-page Illustrations. Square imperial $16 \mathrm{mo}$, cloth extra, gilt edges, $7 s .6 d$. ; plainer binding, $5 s$.

UNDER the Punkah. By Phil RoBinson, Author of "In my Indian Garden." Crown 8vo, limp cloth, 3s. 6d, 
Union Jack (The). Every Boy's Paper. Edited by G. A. Henty. One Penny Weekly, Monthly 6d. Vol. III. commences with the Part for November, 188r, and contains the first Chapters of Three Serial Stories by G. MANVILLE FeNN, LOUIS Rousselet, and W. H. G. KingsToN, from the French of "Landelle." Illustrated by the Best Artists. With the first Part is presented a Photograph of Jules Verne, and a Coloured Plate, "Rounding the Lightship," a Yachting Incident; and this Volume will also contain New Stories by Col. BuTLER, Author of " The Great Lone Land," Jules Verne, an Historical Story by the Editor, \&c., \&c. Volume II. for I88I, beautifully bound in red cloth (royal 4 to), $7 s .6 d$., gilt edges, $8 s$. Beautifully Illustrated with over 400 Illustrations, including 52 full-page Engravings, 8 Steel ditto, 7 Coloured Plates, and Photograph of the Editor.

The Contents comprise:

The Cornet of Horse : a Tale of Marlborough's Wars. By the EDITOR.

The Young Franc-Tireurs : a Tale of the Franco-German War. By the EDIToR.

The Ensign and Middy : a Twie of the Malay Peninsula. By G. Manville FenN.

The Steam. House: The Demon of Cawnpore. A Tale of India. BY JULES VRRNE.

Rawdon School: a Tale of Schoolboy'Life. By Bernard HELDMANN.

Dorrincourt: a Story of a Term there. By Bernard Heldmann. Peyton Phelps; or, Adventures among the Italian Carbonari. By G. STEBbing.

Gerald Rattlin : a Tale of Sea Life. By Gro. Elford.

A Fight in Freedom's Cause.

An Eventful Ride.

The Ghost of Leytonstone Manor.

An Editor's Yarns.

True Tales of Brave Actions.

And numerous other Articles of Interest and Instruction.

A few copies of Volume I., for 1880, still remain, price $6 s$.

Upolu; or, A Paradise of the Gods; being a Description of the Antiquities of the chief Island of the Samoan Group, with Remarks on the Topography, Ethnology, and History of the Polynesian Islands in general. By the late Handery Bathurst STERNDALE. Edited and annotated by his brother, Author of "Seonee," "The Afghan Knife," \&c. 2 vols, demy 8 vo. ICTOR Hugo and his Times. Translated from the French
of A. BARBOU by ELLEN E. FREWER. Izo Illustrations, many of them from designs by Victor Hugo himself. Super-royal $8 \mathrm{vo}$, cloth extra.

Vincent (F.) Norsk, Lapp, and Finn. By FRANK VINCENT, Jun., Author of "The Land of the White Elephant," "Through and Through the Tropics," \&c. 8vo, cloth, with Frontispiece and Map, izs. 


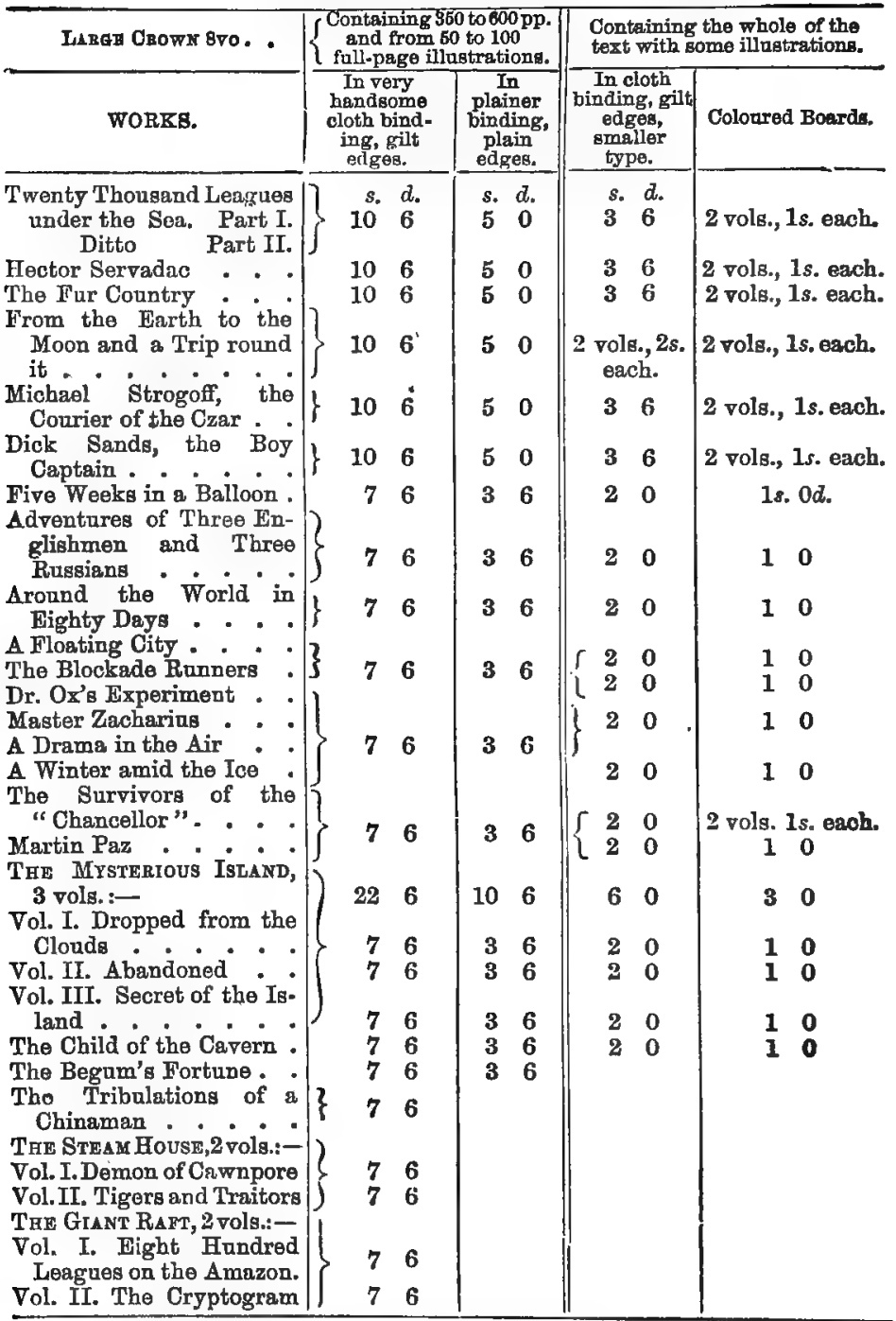

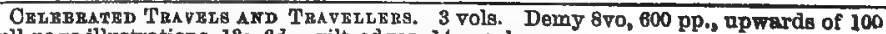
full-page illustrations, 12s. 6d.; gilt edges, 14s, each :-

(1) THE Dxplokation OF THI WORLD.

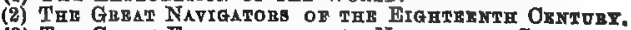

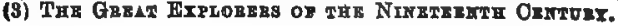


WTITARUNA: A Story of New Zealand Life. By ALEXANDER BATHGATE, Author of "Colonial Experiences." Crown 8vo, cloth, 5 s.

Waller (Rev. C. H.) The Names on the Gates of Pearl, and other/Studies. By the Rev. C. H. Waller, M.A. Second Edition. Crown 8vo, cloth extra, 6 s.

A Grammar and Analytical Vocabulary of the Words in the Greek Testament. Compiled from Briuder's Concordance. For the use of Divinity Students and Greek Testament Classes. By the Rev. C. H. Waller, M.A. Part I. The Grammar. Small post 8vo, cloth, 2s. 6d. Part II. The Vocabulary, $2 s .6 d$.

Adoption and the Covenant. Some Thoughts on Confirmation. Super-royal 16mo, cloth limp, $2 s .6 d$. See aiso "Silver Sockets."

Wanderings South by East : a Descriptive Record of Four Years of Travel in the less known Countries and Islands of the Southern and Eastern Hemispheres, By WALTzR CooTE. 8vo, with very numerous Illustrations and a Map, 21s.

Warner (C. D.) My Summer in a Garden. Rose Library, is. Back-log Studies. Boards, Is. 6d.; cloth, $2 s$. In the Wilderness. Rose Library, Is. Mummies and Moslems. 8vo, cloth, i2s.

Weaving. See "History and Principles."

Where to Find Ferns. By F. G. Heath, Author of "The Fern World," \&c.; with a Special Chapter on the Ferns round London; Lists of Fern Stations, and Descriptions of Ferns and Fern Habitats throughout the British Isles. Crown 8vo, cloth, price 3 s.

White (Rhoda $E$.) From Infancy to Womanhood. $A$ Book of Instruction for Young Mothers. Crown 8vo, cloth, Ios. $6 d$.

Whittier (J.G.) The King's Missive, and later Poems. $18 \mathrm{mo}$, choice parchment cover, 3 s. $6 d$. This book contains all the Poems written by Mr. Whittier since the publication of "Hazel Blossoms."

The Whittier Birthday Book. Extracts from the Author's writings, with Portrait and numerous Illustrations. Uniform with the "Emerson Birthday Book." Square 16mo, very choice binding, 3s, $6 d$. 
Sampson Low, Marston, Eo Co.'s List of Publications.

Wills, A Feze Hints on Proving, without Professional Assistance. By a Probate Court Official. 5th Edition, revised with Forms of Wills, Residuary Accounts, \&c. Fcap. 8vo, cloth limp, Is.

With Axe and Rifle on the Western Prairies. By W. H. G. KINGSTON. With numerous Illustrations, square crown 8 vo, cloth extra, gilt edges, $7 s .6 d$. ; plainer binding, $5 s$.

Woolsey (C. D., LL.D.) Introduction to the Study of Inter. national Law; designed as an Aid in Teaching and in Historical Studies. 5th Edition, demy 8vo, $18 s$.

Words of Wellington: Maxims and Opinions, Sentences and Reflections of the Great Duke, gathered from his Despatches, Letters, and Speeches (Bayard Series). 2s. 6d.

Wreck of the Grosvenor. By W. Clark Russell, Author of " John Holdsworth, Chief Mate," "A Sailor's Sweetheart," \&c. 6s, Third and Cheaper Edition.

Wright (the late Rev. Henry) Sermons. Crown 8vo, with Biographical Preface, Portrait, \&c. [In the press.

\section{IIonชort:}

SAMPSON LOW, MARSTON, SEARLE, \& RIVINGTON, CROWN BUILDINGS, I88, FLEET STREET, E.C. 





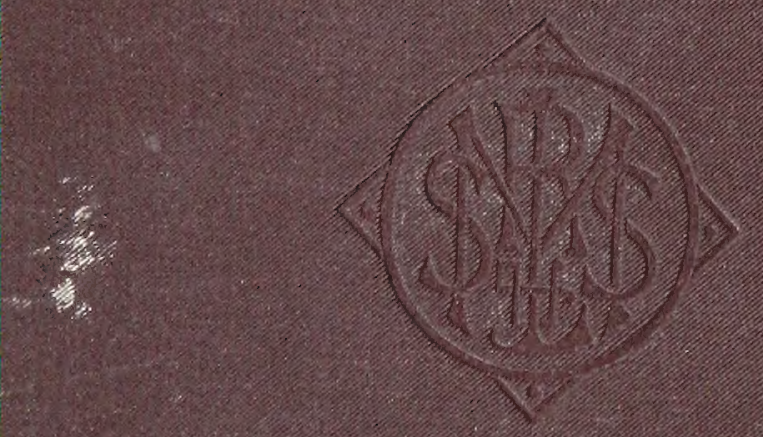

